\title{
Mechanistic Insights into the One-Pot Synthesis of Propargylamines from Terminal Alkynes and Amines in Chlorinated Solvents Catalyzed by Gold Compounds and Nanoparticles
}

\author{
David Aguilar, ${ }^{[\mathrm{a}]}$ Maria Contel, ${ }^{*[\mathrm{~b}]}$ and Esteban P. Urriolabeitia ${ }^{*[a]}$
}

This paper is dedicated to Prof. Richard H. Fish on the occasion of his $70^{\text {th }}$ birthday

\begin{abstract}
Propargylamines can be obtained from secondary amines and terminal alkynes in chlorinated solvents by a three- and two-component synthesis catalyzed by gold compounds and nanoparticles (Au-NP) under mild conditions. The use of dichloromethane allows for the activation of two $\mathrm{C}-\mathrm{Cl}$

bonds and a clean transfer of the methylene fragment to the final product. The scope of the reaction as well as the influence of different gold(III) cycloaurated complexes and salts has been investigated. The involvement of gold nanoparticles generated in situ in the process is discussed and a plausible
\end{abstract}

reaction mechanism is proposed on the basis of the data obtained.

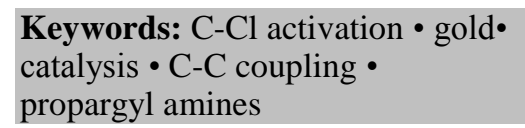

\section{Introduction}

The synthesis of propargylic amines has attracted considerable attention during the last few years due to their pharmaceutical relevance and their importance as building blocks in the preparation of nitrogen-containing molecules and as key intermediates for natural product synthesis. ${ }^{[1]}$ As previously described, ${ }^{[2]}$ there are three main synthetic pathways to obtain propargylamines: a) by stoichiometric nucleophilic reactions, b) by transition-metal catalyzed reactions of imines (or enamines) that can be generated by aldehydes and amines or c) by the catalytic coupling of a $\mathrm{sp}^{3} \mathrm{C}-\mathrm{H}$ adjacent to nitrogen with a terminal alkyne (scheme 1). Many examples of the synthesis of propargylamines by these pathways have been reported. More specifically gold, silver and copper compounds have resulted efficient catalysts in the imine, enamine or imine-generated addition to alkynes ${ }^{[3],[4]}$ including some examples with recyclable gold compounds ${ }^{[5]}$ or nanoparticles. ${ }^{[6]}$ The first example of a $\mathrm{Cu}(\mathrm{I})$ catalyzed alkynylation of several tertiary amines with terminal alkynes in the presence of ${ }^{\mathrm{t}} \mathrm{BuOOH}$ (pathway c, via $\mathrm{sp}^{3} \mathrm{C}-\mathrm{H}$ activation) was reported as well. ${ }^{[2]}$

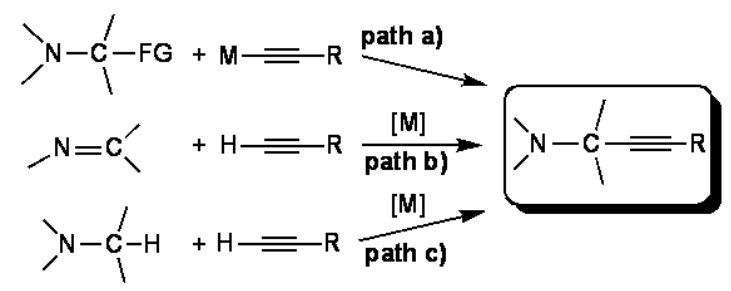

Scheme 1. Different methods to form propargylamines. ${ }^{[2]}$
We report here on a gold-catalyzed three- and two-component synthesis of propargylamines by a route different to those depicted in scheme 1. It implies the use of gold compounds and nanoparticles (Au-NP) as efficient catalysts in the coupling of secondary amines and terminal alkynes in chlorinated solvents. Moreover, when the reaction takes place in $\mathrm{CH}_{2} \mathrm{Cl}_{2}$ (DCM) the coupling involves the methylene fragment from the solvent. Thus, we have found an unexpected role for DCM as a $\mathrm{CH}_{2}$ partner by a gold-catalyzed $\mathrm{C}-\mathrm{Cl}$ bond activation.

Activation of carbon-halogen bonds by transition metal compounds is involved in various organic processes but the activation of the relatively stable $\mathrm{C}-\mathrm{Cl}$ bond is an important subject in environmental chemistry (due to the possible degradation of harmful chlorinated compounds). ${ }^{[7]}$ The activation of dichloromethane (DCM) by late transition metals has been documented for $\mathrm{Co}(\mathrm{I}),{ }^{\left[{ }^{[8]}\right.} \mathrm{Rh}(\mathrm{I}),{ }^{[9]} \mathrm{Rh}(\mathrm{III}),{ }^{[10]} \mathrm{Ru}(\mathrm{II}),{ }^{[11]} \mathrm{Pd},{ }^{[12]}$ and $\mathrm{Pt}(0)^{[12]}$ complexes. The activation of the $\mathrm{C}-\mathrm{Cl}$ bond usually affords $\mathrm{M}-\mathrm{CH}_{2} \mathrm{Cl}$ or $\mathrm{M}-\mathrm{CH}_{2}-\mathrm{M}$ organometallic compounds. Dinuclear gold(I) ylide complexes are also known to add DCM to afford dinuclear $\mathrm{Au}(\mathrm{II})$ derivatives with a methylene bridge. ${ }^{[13]}$ The activation of DCM (wherein DCM serves as a $\mathrm{CH}_{2}$ partner) by early transition metals has also been achieved. ${ }^{[14],[15]} \mathrm{Cr}$ (II) complexes are able to promote DCM methylene transfer to an alkene (cyclopropanation but in a $2 \%$ yield) and the direct stoichiometric methynelation of ketones and aldehydes has been recorded for a bimetallic $\mathrm{Mg} / \mathrm{TiCl}_{4} / \mathrm{THF}$ system. ${ }^{[15]}$ The heterolytic thermal or photocatalytic degration of $\mathrm{DCM}$ to $\mathrm{HCl}$ and $\mathrm{CO}$ in aerobic conditions has been described for heterogenous catalysts and chlorocuprate ions. ${ }^{[16]}$ The $\mathrm{C}-\mathrm{Cl}$ bond activation described here represents an elegant example in the activation of DCM that generates and transfers the methylene fragment catalytically (typically $5 \mathrm{~mol} \%$ cat and amounts as lower as $1 \mathrm{~mol} \%$ for longer reaction times) under mild reaction conditions $\left(50{ }^{\circ} \mathrm{C}\right)$. $\mathrm{Au}(\mathrm{III})$ complexes and $\mathrm{Ag}(\mathrm{I})$ salts have proven effective in similar $\mathrm{C}-\mathrm{Cl}$ bond activations ${ }^{[17]}$ but details of these findings were never published. We report here on the effects of gold compounds and nanoparticles in different oxidation states in such coupling reactions as well as the plausible reaction mechanism. 
Although gold catalyzed reactions have been thoroughly studied in the past decade ${ }^{[18]}$ the study of reaction mechanisms and the isolation/characterization of gold intermediates and/or catalytically active species has not received the same attention. The study of reaction mechanisms is crucial for the rational design of more efficient molecular catalysts.

We have reported on the catalytic and cytotoxic/apoptotic properties $^{[19]}$ displayed by gold(III) compounds containing iminophosphorane ligands (like 1 and 2 , figure 1$)^{[19 a]}$ which efficiently catalyzed the addition of 2-methylfuran and electron-rich arenes to methyl vinyl ketone ${ }^{[19 a, b]}$ and the synthesis of 2,5disubstituted oxazoles via cyclization of $\mathrm{N}$ propargylcarboxamides. ${ }^{[19 b]}$ Iminophosphoranes, $\mathrm{R}_{3} \mathrm{P}=\mathrm{NR}$ ' are a class of compounds that can be readily prepared by different synthetic routes ${ }^{[20]}$ and whose electronic and steric properties may be tuned through appropriate choice of R and R'. Not only does the iminophosphorane $\mathrm{C}, \mathrm{N}$-backbone confer a marked stability to the metallic center in $\mathrm{d}^{8}$ square-planar complexes, but also the $\mathrm{PR}_{3}$ fragment can be used as an 'spectroscopic marker' to follow reactions by ${ }^{31} \mathrm{P}$ NMR. We demonstrated that the real catalytic species in these processes were cationic gold(III) cycloaurated complexes generated by abstraction of the chloride ligands in polar solvents further assisted by silver salts. ${ }^{[19 a]}$

Abstract in Spanish: Se han obtenido propargilaminas a partir de aminas secundarias y alquinos terminales en disolventes clorados a través de una síntesis de dos o tres componentes catalizada por compuestos de oro y nanoparticulas (Au-NP) en condiciones de reacción suaves. El uso de diclorometano permite la activación de dos enlaces $\mathrm{C}-\mathrm{Cl}$ y la posterior trasferencia del fragmento metileno al producto final. El alcance de la reacción así como la influencia de diferentes compuestos ortometalados y sales de oro(III) han sido investigados. Los resultados obtenidos son la base de la discusión sobre la participación de nanopartículas de oro generadas in situ en el proceso así como del posible mecanismo de reacción.

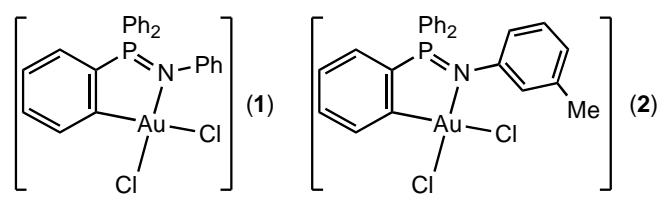

Figure 1. Gold(III) cycloaurated endo compounds with iminophosphorane ligands. ${ }^{19 \mathrm{a}, \mathrm{c}}$

Prompted by these results we decided to study hydroamination reactions of alkynes with these and related cycloaurated complexes.

\section{Results and Discussion}

1.- Scope of the gold-catalyzed synthesis of propargylamines in chlorinated solvents. Formation and catalytic activity of goldnanoparticles under reaction conditions.

We started our research by investigating intramolecular hydroamination reactions. The cyclization of 5-trimethylsilyl-4pentynylamine $\mathbf{3}^{[21]}$ (equation 1) can be catalyzed by $\mathbf{1}, \mathbf{2}$ and

gold(III) salts, affording yields of the intramolecular hydroamination product 4 comparable to those reported for $\mathrm{Na}\left[\mathrm{AuCl}_{4}\right]$ with 5alkynylamines to afford tetrahydropyridines (see SI). ${ }^{[22]}$

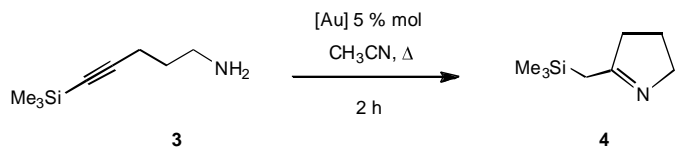

Equation 1. Intramolecular hydroamination of 5-trimethylsilyl-4-pentynylamine (3)

Table 1. Catalytic preparation of $\mathbf{4}$ via intramolecular hydroamination of $\mathbf{3}$ (equation 1).

\begin{tabular}{|c|c|c|c|c|}
\hline Entry & catalyst $(\mathrm{mol} \%)$ & $\mathrm{Ag}^{+}(\mathrm{mol} \%)$ & Time & Yield $(\%)^{[\mathrm{a}]}$ \\
\hline 1 & $\mathrm{AuCl}_{3}(5)$ & 0 & $2 \mathrm{~h}$ & 64 \\
\hline 2 & $\mathrm{Na}\left[\mathrm{AuCl}_{4}\right](5)$ & 0 & $2 \mathrm{~h}$ & 85 \\
\hline 3 & $1(5)$ & 0 & $2 \mathrm{~h}$ & 61 \\
\hline 4 & $1(5)$ & $\operatorname{AgOTf}(11)$ & $2 \mathrm{~h}$ & 80 \\
\hline 5 & $1(5)$ & $\operatorname{AgOTf}(6.1)$ & $2 \mathrm{~h}$ & 73 \\
\hline 6 & $1(5)$ & 0 & $2 \mathrm{~h}$ & 65 \\
\hline 7 & $2(5)$ & $\operatorname{AgOTf}(11)$ & $2 \mathrm{~h}$ & 79 \\
\hline 8 & $2(5)$ & $\operatorname{AgOTf}(6.1)$ & $2 \mathrm{~h}$ & 70 \\
\hline
\end{tabular}

[a] Isolated yields

We have also studied the catalytic activity of $\mathbf{1}$ in intermolecular hydroamination processes with terminal alkynes and secondary amines. However, when $\mathrm{Bu}_{2} \mathrm{NH} \mathbf{5 b}$ is added to $\mathrm{HC} \equiv \mathrm{CPh} \mathbf{6 a}$ in THF or toluene in presence of $1\left(5 \mathrm{~mol} \%, 50{ }^{\circ} \mathrm{C}, 24 \mathrm{~h}\right)$ the expected intermolecular hydroamination product is not obtained and the unreacted starting materials are recovered instead. Surprisingly, when dichloromethane was employed we obtained propargylamine 7ba (equation 2). $7 \mathbf{b a}$ comes from a three-component coupling of the amine $\mathbf{5 b}$, the alkyne $\mathbf{6 a}$ and the $\mathrm{CH}_{2}$ fragment from the solvent DCM as it will be demonstrated later on.

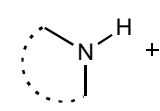

5 a $\mathrm{Me}_{2} \mathrm{NH}$

$5 \mathbf{b ~ B u} \mathrm{Bu}_{2} \mathrm{NH}$

$5 \mathrm{c} \mathrm{Hex}_{2} \mathrm{NH}$

$5 \mathrm{~d} \mathrm{Oc}_{2} \mathrm{NH}$

5e Piperidine

Equation 2. Three-component synthesis of propargylamines.

We explored the scope of the reaction for the cycloaurated gold compound $\mathbf{1}$ as catalyst in the same reaction conditions $(2 \mathrm{mmol}$ alkyne, $2 \mathrm{mmol}$ amine, $5 \mathrm{~mol} \% \mathrm{1}, 24 \mathrm{~h}, 50{ }^{\circ} \mathrm{C}$ ) for three different terminal alkynes and for 5 different secondary amines (Table 2). No 
reaction was observed between 1-decyne and $\mathrm{HNMe}_{2}$. Better yields were obtained with $\mathrm{Bu}_{2} \mathrm{NH}$ than with $\mathrm{Me}_{2} \mathrm{NH}$, probably due to the high volatility of the dimethylamino derivatives. The reaction seems to be very sensitive to the nature of the amine, since no reaction was observed between the above mentioned alkynes and $\mathrm{Ph}_{2} \mathrm{NH}, \mathrm{Cy}_{2} \mathrm{NH}$, ${ }^{\mathrm{i}} \mathrm{Pr}_{2} \mathrm{NH}$ or $\mathrm{MeBnNH}$. Amines with linear $\mathrm{N}$-alkylic chains are the best tolerated and we observed that more basic amines such as $\mathrm{Bu}_{2} \mathrm{NH}$ and piperidine gave better results (dimethylamino derivatives were more volatile and gave lower isolated yields). The reaction is also sensitive to the nature of the solvent: while $\mathrm{CH}_{2} \mathrm{Br}_{2}$ can be used instead of $\mathrm{CH}_{2} \mathrm{Cl}_{2}$, other chlorinated solvents as $\mathrm{CHCl}_{3}$ or $\left(\mathrm{ClCH}_{2}\right)_{2}$ do not give detectable coupling products as it will be shown later on. Preliminary reactions with a higher catalyst loading $(10 \mathrm{~mol} \%)$ and a mol ratio 1 alkyne 1.2 amine afforded higher yields (see table 7 and table 1 in SI) but we optimized the reaction conditions to have a lower catalyst amount and a 1:1 mol ratio (alkyne:amine).

Table 2. Three-component synthesis ${ }^{[\mathrm{a}],[\mathrm{b}]}$ of propargylamines in DCM with $\mathbf{1}$ as the catalyst (equation 2)

\begin{tabular}{cccc}
\hline & $\mathrm{PhC} \equiv \mathrm{CH}(\mathbf{6 a})$ & $\mathrm{Me}_{3} \mathrm{CC} \equiv \mathrm{CH}(\mathbf{6 b})$ & $\mathrm{Me}\left(\mathrm{CH}_{2}\right)_{7} \mathrm{C} \equiv \mathrm{CH}(\mathbf{6 c})$ \\
\hline $\mathrm{Me}_{2} \mathrm{NH}(\mathbf{5 a})$ & $15 \%(7 \mathbf{a a})$ & $17 \%(\mathbf{7 a b})$ & $0 \%(\mathbf{7 a c})$ \\
${ }^{\mathrm{n}} \mathrm{Bu}_{2} \mathrm{NH}(\mathbf{5 b})$ & $58 \%$ (7ba) & $71 \%(\mathbf{7 b b})$ & $57 \%(\mathbf{7 b c})$ \\
${ }^{\mathrm{n}} \mathrm{Hex}_{2} \mathrm{NH}(\mathbf{5 c})$ & $22 \%(\mathbf{7 c a})$ & $21 \%(\mathbf{7 c b})$ & $30 \%(\mathbf{7 c c})$ \\
${ }^{\mathrm{n}} \mathrm{Oc}_{2} \mathrm{NH}(\mathbf{5 d})$ & $70 \%(\mathbf{7 d a})$ & $36 \%(\mathbf{7 d b})$ & $51 \%(\mathbf{7 d c})$ \\
$\operatorname{piperidine~(5e)~}$ & $60 \%(\mathbf{7 e a})$ & $70 \%(\mathbf{7 e b})$ & $55 \%(\mathbf{7 e c})$ \\
\hline
\end{tabular}

[a] Isolated yields. [b] reaction conditions: $5 \% \mathrm{~mol}$ cat $\mathbf{1}, 5 \mathrm{~mL} \mathrm{CH}_{2} \mathrm{Cl}_{2}, 2 \mathrm{mmol}$ alkyne, $2 \mathrm{mmol}$ amine, $24 \mathrm{~h}, 50{ }^{\circ} \mathrm{C}$.

Besides, the nature of the alkyne exerts a critical influence over the general process, as depicted in equation 3. The reaction of $\mathrm{Me}_{3} \mathrm{SiC} \equiv \mathrm{CH}(\mathbf{6 d})$ with $\mathrm{R}_{2}{ }_{2} \mathrm{NH}(\mathbf{5 a - 5 e})$ in $\mathrm{DCM}$ under the same conditions gives two different propargylamines. The main product of the mixture is the DCM activation product (7ad-7ed), while the minor one (8ad-8ed) is the formal result of the coupling of one ${ }^{2}{ }_{2} \mathrm{~N}$ fragment, one $\mathrm{Me}_{3} \mathrm{SiC} \equiv \mathrm{C}$ unit and a $\mathrm{CH}(\mathrm{Me})$ group that comes from a second $\mathrm{Me}_{3} \mathrm{SiC} \equiv \mathrm{CH}$ alkyne molecule (vide infra). The nature of the silyl substituent is crucial for the synthesis of compound $\mathbf{8}$. For instance, the terminal alkyne $\mathrm{Me}_{3} \mathrm{CC} \equiv \mathrm{CH}(\mathbf{6 b})$ does not afford propargylamines of the type $\mathbf{8}$ with a $\mathrm{Me}_{3} \mathrm{CC} \equiv \mathrm{C}$ unit.

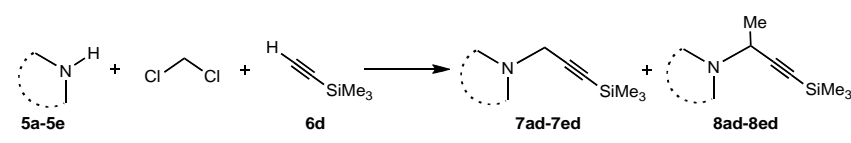

Equation 3. Two- $v s$ three-component synthesis in the case of trimethylsilylacetylene.

Table 3. Two vs three-component synthesis ${ }^{[\mathrm{a}],[\mathrm{b}]}$ of propargylamines in DCM with $\mathbf{1}$ as the catalyst (equation 3).

$\frac{\mathrm{Me}_{3} \mathrm{SiC} \equiv \mathrm{CH}(\mathbf{6 d})}{\mathrm{Me}_{2} \mathrm{NH}(\mathbf{5 a}) \quad 55 \%(\mathbf{7 a d} / \mathbf{8 a d}: 1 / 0.2)}$

\section{${ }^{\mathrm{n}} \mathrm{Bu}_{2} \mathrm{NH}(\mathbf{5 b}) \quad 95 \%(\mathbf{7 b d} / \mathbf{8 b d}: 1 / 0.5)$ \\ ${ }^{\mathrm{n}} \mathrm{Hex}_{2} \mathrm{NH}(\mathbf{5 c}) \quad 39 \%(\mathbf{7 c d} / \mathbf{8 c d}: 1 / 0.05)$ \\ ${ }^{\mathrm{n}} \mathrm{Oc}_{2} \mathrm{NH}(\mathbf{5 d}) \quad 40 \%(\mathbf{7 d d} / \mathbf{8 d d}: 1 / 0.3)$ \\ piperidine (5e) $\quad 65 \%($ (7ed/8ed: $1 / 0.0)$}

[a] Isolated yields. [b] reaction conditions: $5 \% \mathrm{~mol}$ cat $1,5 \mathrm{~mL} \mathrm{CH}_{2} \mathrm{Cl}_{2}, 2 \mathrm{mmol}$ alkyne, $2 \mathrm{mmol}$ amine, $24 \mathrm{~h}, 50^{\circ} \mathrm{C}$.

8ed is not formed under the reaction conditions. 8bd can be obtained as the exclusive product under similar reaction conditions in chlorinated solvents such as $\mathrm{CHCl}_{3}$ or $\mathrm{ClCH}_{2} \mathrm{CH}_{2} \mathrm{Cl}$ with yields of 90\%. A similar reaction between $\mathrm{Et}_{2} \mathrm{NH}$ and acetylene (13.6 atm) to afford 3-diethylaminobut-1-yne catalyzed by $\mathrm{CuBr}(20 \mathrm{~mol} \%)$ in $\mathrm{THF}$ at $100{ }^{\circ} \mathrm{C}$ was described as early as $1949 .{ }^{[23]}$

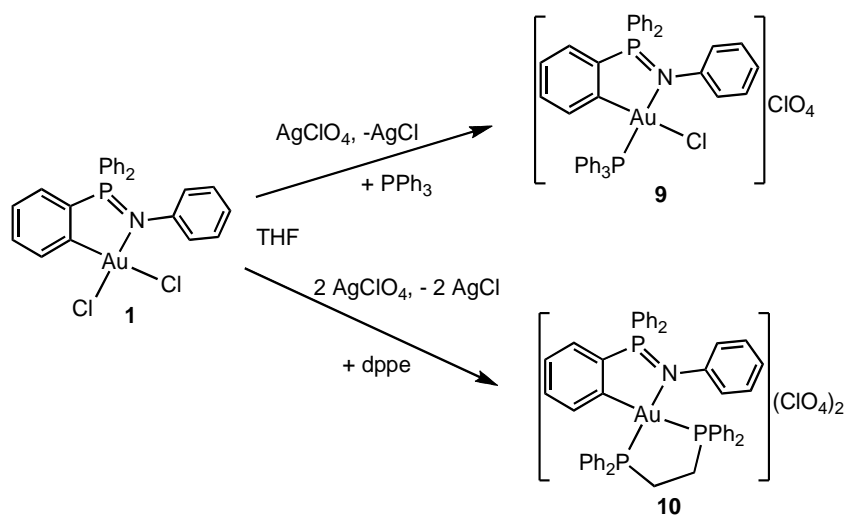

Scheme 2. Synthesis of new cationic cycloaurated endo derivatives 9 and 10 with phosphine ligands.

We tested other gold(III) derivatives with different charges such as the simple gold(III) salt $\mathrm{K}\left[\mathrm{AuCl}_{4}\right]$ (anionic) and new cationic cycloaurated phosphine-containing derivatives $\mathbf{9}$ and $\mathbf{1 0}$ (Scheme 2).

The synthesis and characterization of $\mathbf{9}$ and $\mathbf{1 0}$ are described in the experimental section. Mono- $\mathbf{9}$ and di-cationic $\mathbf{1 0}$ derivatives are cleanly obtained from the organometallic gold(III) endo derivative $\mathbf{1}^{[19 a]}$ by removal of one or two chloride ligands with a silver salt and addition of a mono $\left(\mathrm{PPh}_{3}\right)$ or bis-phosphine (dppe) respectively.

With the salt $\mathrm{K}\left[\mathrm{AuCl}_{4}\right]$ as catalyst we studied the addition reaction of the secondary amines $\mathbf{5 a - 5 e}$ to the terminal alkynes $\mathbf{6 a -}$ 6c in DCM (equation 2, table 4). The results were comparable to those obtained with the cycloaurated derivative 1 (slightly higher yields in this case). More basic amines gave better isolated yields. We also could reduce the catalyst load up to $1 \mathrm{~mol} \%$ without loss of conversion $(83 \%)$, but at longer reaction times $(72 \mathrm{~h})$ to obtain propargylamine $\mathbf{7 b a}$ (table 7).

Table 4. Three-component synthesis ${ }^{[\mathrm{a},[\mathrm{b}]}$ of propargylamines in DCM with $\mathrm{K}\left[\mathrm{AuCl}_{4}\right]$ as the catalyst (equation 2).

\begin{tabular}{cccc}
\hline & $\mathrm{PhC} \equiv \mathrm{CH}(\mathbf{6 a})$ & $\mathrm{Me}_{3} \mathrm{CC} \equiv \mathrm{CH}(\mathbf{6 b})$ & $\mathrm{Me}\left(\mathrm{CH}_{2}\right)_{7} \mathrm{C} \equiv \mathrm{CH}(\mathbf{6 c})$ \\
\hline $\mathrm{Me}_{2} \mathrm{NH}(\mathbf{5 a})$ & $35 \%(\mathbf{7 a a})$ & $30 \%(\mathbf{7 a b})$ & $0 \%(\mathbf{7 a c})$
\end{tabular}




\begin{tabular}{cccc}
${ }^{\mathrm{n}} \mathrm{Bu}_{2} \mathrm{NH}(\mathbf{5 b})$ & $76 \%(7 \mathbf{b a})$ & $80 \%(7 \mathbf{b b})$ & $60 \%(7 \mathbf{b c})$ \\
${ }^{\mathrm{n}} \mathrm{Hex}_{2} \mathrm{NH}(\mathbf{5 c})$ & $32 \%(7 \mathbf{c a})$ & $30 \%(7 \mathbf{7 b})$ & $35 \%(7 \mathbf{c c})$ \\
${ }^{\mathrm{n}} \mathrm{Oc}_{2} \mathrm{NH}(\mathbf{5 d})$ & $61 \%(7 \mathbf{d a})$ & $41 \%(\mathbf{7 d b})$ & $73 \%(\mathbf{7 d c})$ \\
piperidine (5e) & $78 \%(7 \mathbf{e a})$ & $80 \%(7 \mathbf{7 b})$ & $68 \%(7 \mathbf{e c})$ \\
\hline
\end{tabular}

[a] Isolated yields. [b] reaction conditions: $5 \%$ mol cat $\mathrm{K}\left[\mathrm{AuCl}_{4}\right.$ ], $5 \mathrm{~mL} \mathrm{CH}_{2} \mathrm{Cl}_{2}, 2 \mathrm{mmol}$ alkyne, $2 \mathrm{mmol}$ amine, $24 \mathrm{~h}, 50^{\circ} \mathrm{C}$.

Moreover, the catalytic activity and selectivity of $\mathrm{K}\left[\mathrm{AuCl}_{4}\right]$ is similar to that of $\mathbf{1}$ when amines are added to the terminal alkyne $\mathrm{Me}_{3} \mathrm{SiC} \equiv \mathrm{CH}$ (6d) (Table 5 and equation 3 ). With the more basic amines in this case the selectivity towards the DCM activation product is higher. Again 8ed (with piperidine) could not be obtained under reaction conditions.

Table 5. Two vs three-component synthesis ${ }^{[\mathrm{a}],[\mathrm{b}]}$ of propargylamines in DCM with $\mathrm{K}\left[\mathrm{AuCl}_{4}\right]$ as the catalyst (equation 3).

\begin{tabular}{cc}
\hline & $\mathbf{M e}_{3} \mathbf{S i C} \equiv \mathbf{C H}(6 \mathrm{~d})$ \\
\hline $\mathrm{Me}_{2} \mathrm{NH}(\mathbf{5 a})$ & $60 \%(\mathbf{7 a d} / \mathbf{8 a d}: 1 / 0.3)$ \\
${ }^{\mathrm{n}} \mathrm{Bu}_{2} \mathrm{NH}(\mathbf{5 b})$ & $90 \%(\mathbf{7 b d} / \mathbf{8 b d}: 1 / 0.1)$ \\
${ }^{\mathrm{n}} \mathrm{Hex}{ }_{2} \mathrm{NH}(\mathbf{5 c})$ & $46 \%(\mathbf{7 c d} / \mathbf{8 c d}: 1 / 0.05)$ \\
${ }^{\mathrm{n}} \mathrm{Oc}_{2} \mathrm{NH}(\mathbf{5 d})$ & $42 \%(\mathbf{7 d d} / \mathbf{8 d d}: 1 / 0.8)$ \\
piperidine (5e) & $73 \%(\mathbf{7 e d} / \mathbf{8 e d}: 1 / 0.0)$ \\
\hline
\end{tabular}

[a] Isolated yields. [b] reaction conditions: $5 \% \mathrm{~mol}$ cat $\mathrm{K}\left[\mathrm{AuCl}_{4}\right], 5 \mathrm{~mL} \mathrm{CH} \mathrm{Cl}_{2}, 2 \mathrm{mmol}$ alkyne, $2 \mathrm{mmol}$ amine, $24 \mathrm{~h}, 50^{\circ} \mathrm{C}$.

With $\mathrm{K}\left[\mathrm{AuCl}_{4}\right]$ we could reduce the catalyst load (table 7) to 1 mol\% (for amine $\mathbf{5 b}$ and alkyne $\mathbf{6 d}$ ) and we obtained the mixture of products in $91 \%$ yield and in a similar ratio $\mathbf{7 b d} / \mathbf{8 b d}(1 / 0.08)$ but at longer reaction times ( $72 \mathrm{~h} v s 24 \mathrm{~h}$ ). Exchanging DCM for other chlorinated solvents resulted in the clean synthesis of product $\mathbf{8 b d}$ and with $\mathrm{CHCl}_{3}$ or $\mathrm{ClCH}_{2} \mathrm{CH}_{2} \mathrm{Cl}$ the yields of isolated product were 90 and 93\% respectively. In the case of the reaction for amine $\mathbf{5 b}$ and alkyne $\mathbf{6 d}$ in non chlorinated solvents such as THF or $\mathrm{CH}_{3} \mathrm{CN}$ the $\mathrm{C}-\mathrm{Cl}$ activation product $\mathbf{7 b d}$ is obviously not observed and instead the chiral product $\mathbf{8 b d}$ is obtained in low yields (40 and 10\% respectively) together with mostly starting materials and some unidentified amine derivatives.

The results for the catalytic activity of the mono- and di-cationic cycloaurated derivatives $\mathbf{9}$ and $\mathbf{1 0}$ are collected in table 6 . We studied the standard reaction in DCM and the particular case of the $\mathrm{Me}_{3} \mathrm{SiC} \equiv \mathrm{CH}$ alkyne (6d) with ${ }^{\mathrm{n}} \mathrm{Bu}_{2} \mathrm{NH}(\mathbf{5 b})$. The catalytic activity is similar to that observed for $\mathbf{1}$ and $\mathrm{K}\left[\mathrm{AuCl}_{4}\right]$ for phenylacetylene (6a) but it decreases for the other alkynes. In the case of trimethylsilylacetylene (6d) the propargylamine obtained is exclusively that derived from the DCM activation (7ba).

Table 6. Three- and two- vs three-component synthesis ${ }^{[a],[b]}$ of propargylamines derived from ${ }^{\mathrm{n}} \mathrm{Bu}_{2} \mathrm{NH}(\mathbf{5 b})$ in DCM with cationic cyclourated gold(III) derivatives $\mathbf{9}$ and $\mathbf{1 0}$ as catalysts (equations 2 and 3).

\begin{tabular}{|c|c|c|c|c|}
\hline & $\mathrm{PhC} \equiv \mathrm{CH}(2 \mathrm{a})$ & $\mathrm{Me}_{3} \mathrm{CC} \equiv \mathrm{CH}(2 \mathrm{~b})$ & $\begin{array}{c}\mathrm{Me}\left(\mathrm{CH}_{2}\right)_{7} \mathrm{C} \equiv \\
\mathrm{CH}(2 \mathrm{c})\end{array}$ & $\mathrm{Me}_{3} \mathrm{SiC} \equiv \mathrm{CH}(2 \mathrm{~d})$ \\
\hline (9) & $80 \%$ (7ba) & $60 \%(7 \mathbf{b b})$ & $47 \%(7 \mathbf{b c})$ & $\begin{array}{c}34 \% \text { (7bd/8bd: } \\
1 / 0.0)\end{array}$ \\
\hline (10) & $75 \%$ (7ba) & $65 \%(7 \mathbf{b b})$ & $43 \%$ (7bc) & $\begin{array}{c}30 \%(7 \mathbf{b d} / \mathbf{8 b d}: \\
1 / 0.0)\end{array}$ \\
\hline
\end{tabular}

[a] Isolated yields. [b] reaction conditions: $5 \%$ mol cat (9) or (10), $5 \mathrm{~mL} \mathrm{CH}_{2} \mathrm{Cl}_{2}, 2$ mmol alkyne, $2 \mathrm{mmol}$ amine, $24 \mathrm{~h}, 50^{\circ} \mathrm{C}$.

In contrast to our previous studies with gold(III) complexes for which we demonstrated that the catalytically active species were discrete gold(III) derivatives, ${ }^{[19]}$ it seems that the real catalytically active species here are gold-nanoparticles generated in situ at the beginning of the reaction by reduction of the gold precursors with the amine. We always observed immediate change of the color of the gold(III)-containing solutions from yellow to deep-red by addition of the amine in all reactions. Au-NP have been reported to be formed by reduction of gold(III) salts with amines. ${ }^{[24]}$ Moreover, $\mathrm{Au}(\mathrm{I})$ halides, $\mathrm{AuCl}$ and $\mathrm{AuBr}$ can also generate $\mathrm{Au}-\mathrm{NP}$ with narrow size distribution in mild conditions $\left(60^{\circ} \mathrm{C}\right)^{[25]}$ similar to those used in our catalytic conditions $\left(50^{\circ} \mathrm{C}\right)$.

Thus we have been able to characterize these deep-red solutions to test for the presence of gold colloids in the case of the catalytic process to obtain $\mathbf{7 b a}$ with $\mathrm{K}\left[\mathrm{AuCl}_{4}\right]$ (nano-11). Indeed, TEM analysis these gold materials (aliquot of the solution deposited onto carbon coated copper grid and blotted) as well as X-ray diffraction studies (from the powdered sample by removal of all solvents) confirmed the formation of homogeneous nanoparticles with a $3 \mathrm{~nm}$ radius (SI). As expected, isolable gold nanoparticles prepared by literature methods (nano-12), ${ }^{[26]}$ were catalytically active in the reactions described here in DCM (table 7) and the yields obtained of products $\mathbf{7 b a}$ and $\mathbf{7 b d} / \mathbf{8 b d}$ were similar to those obtained with $\mathrm{K}\left[\mathrm{AuCl}_{4}\right]$.

Table 7. Synthesis of progargylamines $7 \mathbf{b a}, \mathbf{7 b d}$ and $\mathbf{8 b d}$ in DCM with isolated Au-NP (nano-12) synthesized via the Brust ${ }^{[26]}$ method. A comparison with $\mathrm{K}\left[\mathrm{AuCl}_{4}\right]$ is given in the table.

\begin{tabular}{|c|c|c|}
\hline & $7 \mathrm{bd}+8 \mathrm{bd}$ & $7 \mathbf{b a}$ \\
\hline Nano-12 ${ }^{[a]}$ & $94 \%$ (7bd/8bd: $1 / 0.5)$ & $75 \%$ \\
\hline $\mathrm{K}\left[\mathrm{AuCl}_{4}\right]^{[\mathrm{a}]}$ & 93\% (7bd/8bd: 1/0.5) & $75 \%$ \\
\hline Nano-12 ${ }^{[b]}$ & $90 \%$ (7bd/8bd: 1/0.05) & $76 \%$ \\
\hline $\mathrm{K}\left[\mathrm{AuCl}_{4}\right]^{[\mathrm{a}]}$ & $91 \%$ (7bd/8bd: 1/0.08) & $83 \%$ \\
\hline
\end{tabular}

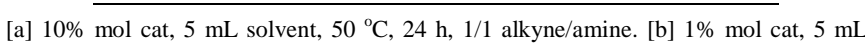
solvent, $50{ }^{\circ} \mathrm{C}, 72 \mathrm{~h}, 1 / 1.2$ alkyne/amine.

\section{2.- Study of the reaction mechanism of these reactions}

We have elucidated the origin of the $\mathrm{CH}_{2}$ (in propargylamines of type 7) and $\mathrm{C}(\mathrm{H}) \mathrm{Me}$ (in propargylamines of type 8) fragments. NMR experiments proved that the $\mathrm{CH}_{2}$ fragment in 7 ba comes from the DCM solvent. When the $\mathrm{K}\left[\mathrm{AuCl}_{4}\right]$-catalyzed reaction of 
$\mathrm{PhC} \equiv \mathrm{CH}(\mathbf{6 a})$ and $\mathrm{Bu}_{2} \mathrm{NH}(\mathbf{5 b})$ was run in $\mathrm{CD}_{2} \mathrm{Cl}_{2}$ the signal in the ${ }^{1} \mathrm{H}$ NMR corresponding to the $\mathrm{CH}_{2}$ fragment at $3.63 \mathrm{ppm}$ in the final product (7ba-d $\mathbf{d}_{\mathbf{2}}$ ) disappeared (Figure 2). The nature of the new isolated compound incorporating deuterium $\left(\mathrm{CD}_{2}\right.$ fragment) was further confirmed by ${ }^{2} \mathrm{H}$ NMR and mass spectrometry (SI).

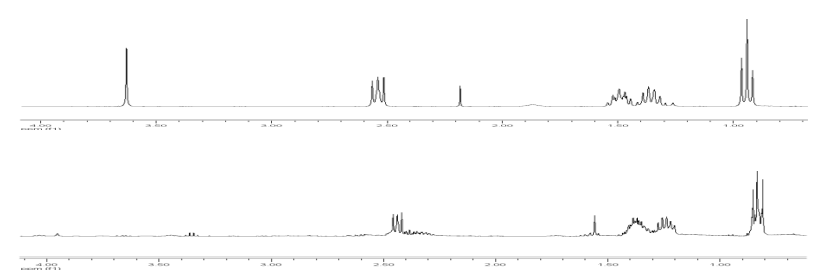

Figure $2 .{ }^{1} \mathrm{H}$ NMR spectra of $\mathbf{7 b a}(\mathrm{a})$ and $\mathbf{7} \mathbf{b a}-\mathbf{d}_{\mathbf{2}}$ (b)

In the case of the $\mathrm{C}(\mathrm{H}) \mathrm{Me}$ fragment we have excluded the participation of the solvent running an experiment between $\mathrm{Me}_{3} \mathrm{SiC} \equiv \mathrm{CH}(\mathbf{6 d})$ and $\mathrm{Bu}_{2} \mathrm{NH}(\mathbf{5 b})$ in $\mathrm{CDCl}_{3}$; as expected, $8 \mathbf{b d}$ did not show incorporation of ${ }^{2} \mathrm{H}$ at the $\mathrm{C}(\mathrm{H}) \mathrm{Me}$ unit. The generation of the $\mathrm{C}(\mathrm{H}) \mathrm{Me}$ unit can be explained by a desilylation reaction of the starting alkyne. The reaction of an equimolar mixture of $\mathrm{Me}_{3} \mathrm{SiC} \equiv \mathrm{CH}(\mathbf{6 d})$ and $\mathrm{PhC} \equiv \mathrm{CH}(\mathbf{6 a})$ with 2 eqs. of $\mathrm{Bu}_{2} \mathrm{NH}(\mathbf{5 b})$ in $\mathrm{DCM}$ as solvent gives the cross-coupling product $\mathrm{PhC} \equiv \mathrm{C}-\mathrm{C}(\mathrm{H}) \mathrm{Me}-$ $\mathrm{NBu}_{2}(\mathbf{1 3})$ in $15 \%$ yield, together with the expected products $7 \mathbf{b a}$ (4\%), 7bd (41\%) and 8bd (40\%) (Equation 4, SI). This shows clearly that the incorporation of the $\mathrm{C}(\mathrm{H}) \mathrm{Me}$ unit is related to the presence of the silyl-alkyne in the starting mixture, since the reaction of $\mathrm{PhC} \equiv \mathrm{CH}(\mathbf{6 a})$ with $\mathrm{Bu}_{2} \mathrm{NH}(\mathbf{5 b})$ gives only $\mathbf{7 b a}$.

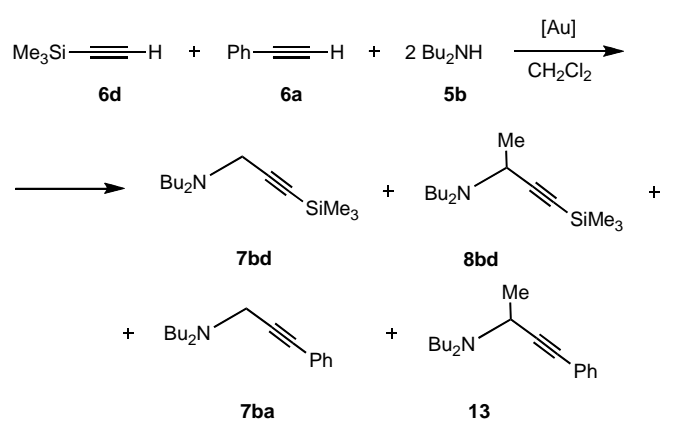

Equation 4. Gold-catalyzed cross-coupling reaction of $\mathrm{Bu}_{2} \mathrm{NH}(5 \mathrm{~b})$ with two different alkynes (trimethylsilylacetylene 6d and phenylacetylene 6a) in DCM.

The definitive proof of the origin of the $\mathrm{C}(\mathrm{H}) \mathrm{Me}$ fragment comes from the reaction of enriched alkyne $\mathrm{Me}_{3} \mathrm{Si}^{13} \mathrm{C} \equiv{ }^{13} \mathrm{CH}\left({ }^{13} \mathrm{C}\right.$ 6d) with $\mathrm{Bu}_{2} \mathrm{NH}(\mathbf{5 b})\left(\mathrm{CH}_{2} \mathrm{Cl}_{2}, 24 \mathrm{~h}, 50{ }^{\circ} \mathrm{C}\right)$. The ${ }^{13} \mathrm{C}\left\{{ }^{1} \mathrm{H}\right\} \mathrm{NMR}$ spectrum of the resulting mixture shows unambiguously the presence of a spin system due to the ${ }^{13} \mathrm{C} \equiv{ }^{13} \mathrm{C}-{ }^{13} \mathrm{C}(\mathrm{H})-\left({ }^{13} \mathrm{CH}_{3}\right)$ skeleton: the signal at about $50 \mathrm{ppm}$, assigned to the ${ }^{13} \mathrm{CH}$ carbon, appears as a ddd by coupling with the other three ${ }^{13} \mathrm{C}$ nuclei $\left({ }^{13} \mathrm{C}\right.$ 8bd), Fig 3 and detailed assignation of signals in SI). A proposal to account for the formation of propargylamines of the type $\mathbf{8}$ is outlined in equation 5 .

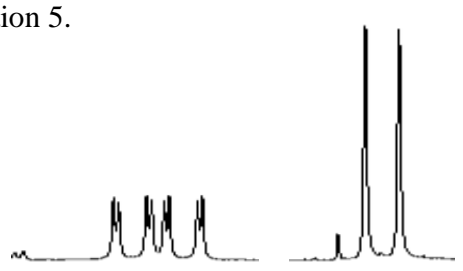

Figure 3. ${ }^{13} \mathrm{C}$ NMR spectrum of ${ }^{13} \mathrm{C}$-8bd showing the ${ }^{13} \mathrm{C} \equiv{ }^{13} \mathrm{C}^{13} \mathrm{CH}^{13} \mathrm{CH}_{3}$ spin system ( $\mathrm{CH}$ and $\mathrm{CH}_{3}$ signals).

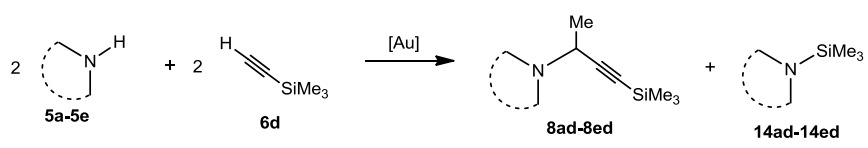

Equation 5. Formation of propargylamines of type 8 from trimethylsilylacetylene (6d).

We wondered at this point what could be the role of the gold nanoparticles (Au-NP) in the catalytic process. One important consideration is to know the oxidation state of the gold-containing species (mainly nanoparticles) generated in situ by reduction of the gold(III) complexes by the secondary amine before the addition of the terminal alkyne and the subsequent catalytic reaction which takes place. In order to get an idea we run an X-ray photoelectron spectroscopy (XPS) experiment (see explanations in the experimental section) of the solution generated by the reduction of $\mathrm{K}\left[\mathrm{AuCl}_{4}\right]$ with $\mathrm{Bu}_{2} \mathrm{NH}(\mathbf{5 b})$ in DCM (nano-14). In figure 4 we can see the deconvolution spectra for Au4f. The subsequent assignment of oxidation states in these colloids is shown in table 8 .

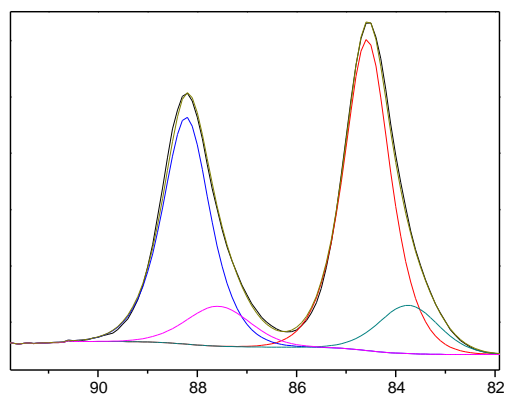

Figure 4. XPS deconvolution spectra from nano-14 generated by reduction of $\mathrm{K}\left[\mathrm{AuCl}_{4}\right]$ by amine (equation 2 , table 4 , table 8 ).

Table 8. Assignation of oxidation states in the XPS deconvolution experiment from nano-14 (Fig. 5).

\begin{tabular}{cccc}
\hline & \multicolumn{2}{c}{ Binding Energy $(\mathrm{eV})$} & \\
\cline { 2 - 3 } Assignation & $4 \mathrm{f} 7 / 2$ & \% area \\
& 83.8 & $4 \mathrm{f} 5 / 2$ & \\
$\mathrm{Au}(0)$ & 87.7 & $16 \%$ \\
$\mathrm{Au}(\mathrm{I})$ & 84.6 & 88.3 & $84 \%$
\end{tabular}

[a] Isolated yields. [b] reaction conditions: $5 \%$ mol cat (9) or (10), $5 \mathrm{~mL} \mathrm{CH}_{2} \mathrm{Cl}_{2}, 2$ mmol alkyne, $2 \mathrm{mmol}$ amine, $24 \mathrm{~h}, 50^{\circ} \mathrm{C}$. 
Most of the gold species (84\%) are in the oxidation state +1 and $16 \%$ in the oxidation state 0 . The XPS technique can measure the composition of the examined surface up to $10 \mathrm{~nm}$ in depth. We can assume that in a homogeneous sample (like this one, see fig. SI 1 in SI) the composition in the surface is representative for the whole sample. Thus no gold(III) was found in these solutions or in the nanoparticles. In the three-component coupling of aldehydes, terminal alkyne and amine catalyzed by supported $\mathrm{Au}-\mathrm{NP}$ on $\mathrm{CeO}_{2}$ or $\mathrm{ZrO}_{2}$ it was demonstrated that the catalytic activity was directly related to the content of $\mathrm{Au}(\mathrm{III})$ in these nanoparticles. ${ }^{[5 \mathrm{a}]}$ The authors claimed that the support allowed for the stabilization of the gold(III) species to reduction to $\mathrm{Au}(\mathrm{I})$ or metallic gold and a higher catalytic activity. However gold(III) and gold(I) derivatives and unsupported Au-NP had resulted catalytically active in these couplings as well. ${ }^{[4],[5 b-c],[6]}$ In scheme 2 we propose a plausible reaction mechanism for the formation of propargylamines of type 7 (equation 2) in DCM.

The first step of the proposed catalytic cycle is the reduction of all gold(III) complexes and salts by the amine to Au-NP in the oxidation states $\mathrm{Au}(\mathrm{I})-\mathrm{Au}(0)$. The working hypothesis here is that $\mathrm{Au}(\mathrm{I})$ fragments are the catalytically active species in this process. The next step is the addition of the terminal alkynes and the formation of alkynyl-gold(I) species. The synthesis of ethynyl(arene)gold compounds from gold(I) derivatives like $\left[\mathrm{AuCl}\left(\mathrm{SMe}_{2}\right)\right]$ with terminal alkynes and $\mathrm{NEt}_{3}$ as a base has been previously reported. ${ }^{[27]}$ Moreover, the formation of alkynyl-gold(I) and (III) species has been proposed as the first step in the $\mathrm{A}^{3}$ coupling reaction of terminal alkynes, amines and aldehydes to afford propargylamines. ${ }^{[4],[5]}$ The alkynyl-gold(I) species $\mathbf{1 6}$ should react with the DCM and give a $\mathrm{Au}(\mathrm{III})$ species, 17, by oxidative addition of the DCM via activation of one $\mathrm{C}-\mathrm{Cl}$ bond. Such an oxidative addition has been reported for dinuclear gold(I)-ylide derivatives with the formation of dinuclear gold(II) complexes with the methylene group as a bridge ligand. ${ }^{[13]}$ The addition of $\mathrm{CH}_{2} \mathrm{X}_{2}$ with $\mathrm{X}=\mathrm{Br}$, I to dinuclear gold(I) derivatives is also known ${ }^{[28],[29]}$ affording dinuclear gold(II) complexes with the methylene bridging the gold centers ${ }^{[28]}$ or mononuclear gold(III) derivatives. ${ }^{[29]}$ Subsequent reductive elimination of highly reactive 17 would afford the corresponding propargylchloride 19 and gold(I) species 18. Reductive eliminations on alkynyl-gold(III) derivatives have been described before to afford $\mathrm{RC} \equiv \mathrm{C}$-containing products and gold(I) complexes. ${ }^{[30]}$ The reaction of propargylchloride with amine may render the final product 7 . The catalytic cycle can close since $\mathrm{Au}(\mathrm{I})$ species 18 could further react with more alkyne to give $\mathbf{1 6}$. Alternatively, the cycle could be closed by further oxidative addition of propargylchloride to the gold(I) species $\mathbf{1 8}$ to afford gold(III) species 20. By reaction with quaternary ammonium salts, 20 would generate a gold(III) intermediate $\mathbf{2 1}$ containing the propargylic fragment and the amine which by reductive elimination would afford propargylamines 7ae-7de and gold(I) species susceptible to re-start the catalytic cycle.

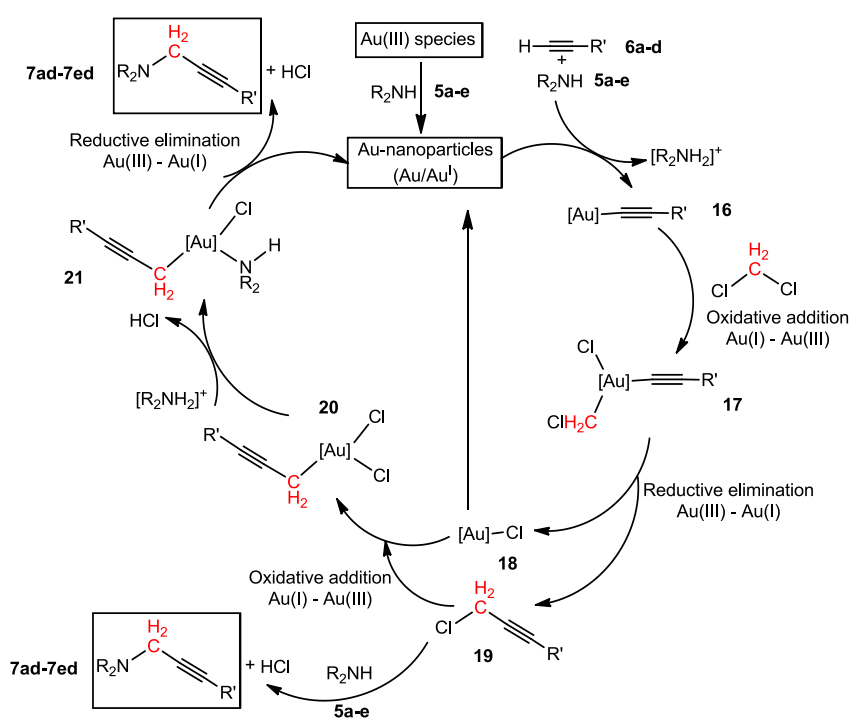

Scheme 3. Proposed reaction mechanism for the gold-catalyzed synthesis of propargylamines of the type 7 in DCM.

We have performed some experiments in order to prove some steps of this proposed mechanism. We tested the catalytic activity of gold(I) derivatives such as $[\mathrm{AuCl}(\mathrm{tht})]$ and $\left[\mathrm{AuCl}\left(\mathrm{PPh}_{3}\right)\right]$ in the formation of propargylamines $\mathbf{7 b a}$ and $\mathbf{7 b d}-\mathbf{8 b d}$ in DCM under standard reaction conditions $(2 \mathrm{mmol}$ alkyne, $2 \mathrm{mmol}$ amine, 5 mol\% cat, $24 \mathrm{~h}, 50{ }^{\circ} \mathrm{C}$ ). Both compounds were able to catalyze the reactions, although slightly lower yields were obtained: a $40-65 \%$ yield of $7 \mathbf{b a}$, compared with an average value of $75 \%$ using gold(III) precursors; and a 52-60\% yield of the mixture 7bd-8bd compared with and average value of $90 \%$ using neutral or anionic gold(III) compounds. In the case of trimethylsilylacetylene, using $\left[\mathrm{AuCl}\left(\mathrm{PPh}_{3}\right)\right]$ as the catalyst, there is complete selectivity towards the DCM activation product $7 \mathbf{b d}$. Interestingly, the catalytic reactions performed with $\mathrm{Au}(\mathrm{I})$ complexes did not develop the deep red color observed in catalysis using $\mathrm{Au}$ (III) complexes. Since we have shown that gold(I) catalyzes efficiently the formation of propargylamines, we wondered about the presence of NP in these reaction mixtures. The TEM analysis of the mixture of $\mathrm{ClAu}($ tht $)$ and $\mathrm{HNBu}_{2}(\mathbf{5 b})$ shows a very small amount (almost zero) of very small NP (about 2-3 nm, see TEM 22 in SI). The influence on stability of the $\mathrm{Au}(\mathrm{I})$ compound of the ligand coordinated to the $\mathrm{Au}(\mathrm{I})-\mathrm{Cl}$ either tht (tetrahydrothiophene) or $\mathrm{PPh}_{3}$ must be strong. $\mathrm{Au}(\mathrm{I})$ halides without other stabilizing ligands are able to afford stable nanoparticles of $12 \mathrm{~nm}$ size radius by reduction with alkylamines ${ }^{[25]}$ In our case it seems that the $\mathrm{Au}(\mathrm{I})$ derivatives with other stabilizing ligands do not produce Au-NP under reaction conditions $\left(50^{\circ} \mathrm{C}\right)$ and in the presence of alkylamines.

The interaction of the AuNP with the alkyne should result in a plausible alkynyl-Au(I) compound, which could also be catalytically active. We have checked this possibility, and we have found that the complex $\left[\mathrm{Ph}_{3} \mathrm{PAuC} \equiv \mathrm{CPh}\right]^{31}$ catalyzes efficiently the coupling between $\mathrm{Bu}_{2} \mathrm{NH}(\mathbf{5 b})$ and $\mathrm{PhCCH}(\mathbf{6 a})$, giving the propargylamine $7 \mathbf{b a}$ in $61 \%$ yield, and giving proof that alkynyl species could be involved in the catalytic cycle.

Table 7. Synthesis of progargylamines $7 \mathbf{b a}, 7 \mathbf{b d}$ and $\mathbf{8 b d}$ in DCM with gold(I) compounds. ${ }^{[a]}$ 


\begin{tabular}{lll}
\hline ClAutht $^{[\mathrm{b}]}$ & $52 \%(\mathbf{7 b d} / \mathbf{8 b d}: 0.7 / 1)$ & $65 \%$ \\
ClAuPPh $_{3}{ }^{[\mathrm{b}]}$ & $60 \%(\mathbf{7 b d} / \mathbf{8 b d}: 1 / 0.0)$ & $40 \%$ \\
\hline
\end{tabular}

[a] Isolated yields. [b] $1 \%$ mol cat, $5 \mathrm{~mL}$ solvent, $50{ }^{\circ} \mathrm{C}, 72 \mathrm{~h}, 1 / 1.2$ alkyne/amine.

The next step is the oxidative addition of the DCM to the alkynyl-Au(I) complex formed. In this respect, we have performed a comparative study of the reaction of $\mathrm{PhC} \equiv \mathrm{CH} \mathbf{6 a}$ with $\mathrm{Bu}_{2} \mathrm{NH} \mathbf{5 b}$ in $\mathrm{CH}_{2} \mathrm{Cl}_{2}$ or $\mathrm{CH}_{2} \mathrm{Br}_{2}$. NMR monitoring of the reaction to give $7 \mathbf{b a}$ shows a faster process for $\mathrm{CH}_{2} \mathrm{Br}_{2}$ (SI). This fact strongly suggests that the incorporation of the solvent to the gold catalyst could proceed through an oxidative addition reaction. At this point we can consider two ways to close the catalytic cycle, as proposed before. In the first one, a reductive elimination in $\mathbf{1 7}$ gives propargyl chloride and a $\mathrm{Au}(\mathrm{I})$ species $\mathbf{1 8}$, which could re-start the catalytic cycle. We tested that the reaction between propargylchloride (from Aldrich) and $\mathrm{Bu}_{2} \mathrm{NH}(\mathbf{5 b})$ to afford propargylamine $7 \mathbf{b a}$ proceeds cleanly in DCM without the assistance of a catalyst (with a slight excess of amine, mol ratio 1 propargylchloride: 1.2 alkylamine). This indicates that the key step of the catalytic process may be indeed the activation of DCM by alkynyl-gold(I) species (mono or polynuclear) formed in situ by reduction of gold(III) complexes by the amine and subsequent reaction of the gold(I) species with terminal alkynes in basic media. An alternative way to close the catalytic cycle implies an oxidative addition of propargylchloride to $\mathrm{Au}(\mathrm{I})$ species $\mathbf{1 8}$, amine coordination and further $\mathrm{C}-\mathrm{N}$ coupling and reductive elimination. With the data obtained we can not discriminate between both pathways.

The fact that the more basic amines give better yields in the processes confirms our hypothesis that gold(III) has to be reduced to lower oxidation states to have a higher catalytic activity. $\mathrm{K}\left[\mathrm{AuCl}_{4}\right]$ and cyclometalated $\mathbf{1}$ give similar yields while the more cationic species with phosphine derivatives give lower yields of product. This may be the combination of factors such as the higher stability of the cationic pincer derivatives towards reduction and/or the ease of formation/stability of the alkynyl-gold derivatives formed in situ. The nano-particle size may play an important role. It has been demonstrated that in the $\mathrm{A}^{3}$ coupling of aldehyde, terminal alkyne and aldehyde by recyclable gold-nanoparticles a size of $20 \mathrm{~nm}$ was the optimum size to afford high yields of products at $75-80{ }^{\circ} \mathrm{C}$ in 12 $\mathrm{h}$ and with a catalyst load of $10 \mathrm{~mol} \%$ Au-NP. ${ }^{[6]}$ We think that cationic derivatives may afford Au-NP with a lesser content of $\mathrm{Au}(\mathrm{I})$ and/or a different size and that this may be the reason for a lower yield. We have already seen that although gold (I) compounds have proven to be catalytically active in the formation of propargylamine $\mathbf{7 b a}$, the yields of isolated product are lower and this could be correlated to the fact that they did not produce considerable amounts of NP under reaction conditions (see TEM for 22 in SI). What it seems clear is that the key steps in the catalytic process are the reduction of gold(III) complexes to gold(I)-containing nanoparticles and the production of catalytically active species able to activate $\mathrm{C}$ $\mathrm{Cl}$ bonds from the DCM.

\section{Conclusion}

In summary, in situ reduction of gold(III) compounds and salts generate gold(I)-containing NP that are efficient catalysts in the onepot synthesis of propargylamines from alkynes and amines in chlorinated solvents in mild conditions. More importantly, we have shown that DCM can be activated by these and some other gold(I) species to serve as a $\mathrm{CH}_{2}$ partner which could lead to potentially relevant gold-catalysed chemical processes.

\section{Experimental Section}

General Methods. Solvents and amines were dried and distilled under argon using standard procedures before use. Elemental analyses were carried out on a Perkin-Elmer 2400-B microanalyser. Infrared spectra $\left(4000-200 \mathrm{~cm}^{-1}\right)$ were recorded on a Perkin-Elmer Spectrum One IR spectrophotometer from nujol mulls between polyethylene sheets. The ${ }^{1} \mathrm{H},{ }^{2} \mathrm{H},{ }^{13} \mathrm{C}\left\{{ }^{1} \mathrm{H}\right\}$ and ${ }^{31} \mathrm{P}\left\{{ }^{1} \mathrm{H}\right\}$ NMR spectra were recorded in $\mathrm{CDCl}_{3}, \mathrm{CD}_{2} \mathrm{Cl}_{2}$ or $\mathrm{CH}_{2} \mathrm{Cl}_{2}\left(7 \mathrm{ba}-\mathrm{d}_{2}\right)$ solutions at 25 ${ }^{\circ} \mathrm{C}$ on Bruker ARX-300, AvanceII-300, Avance-400 and Avance500 spectrometers $(\delta$, ppm; $\mathrm{J}, \mathrm{Hz}) ;{ }^{1} \mathrm{H}$ and ${ }^{13} \mathrm{C}\left\{{ }^{1} \mathrm{H}\right\}$ were referenced using the solvent signal as internal standard while ${ }^{31} \mathrm{P}\left\{{ }^{1} \mathrm{H}\right\}$ was externally referenced to $\mathrm{H}_{3} \mathrm{PO}_{4}(85 \%)$. The mass spectra (MALDI+) and (ESI+) were recorded from $\mathrm{CH}_{2} \mathrm{Cl}_{2}$ or $\mathrm{MeOH}$ solutions on a MALDI-TOF MICROFLEX (Bruker) spectrometer (DCTB as matrix). $\quad 1,^{[18 \mathrm{a}]} \quad 3,^{[20]} \quad \mathrm{Nano}-12,^{[26]} \quad\left[\mathrm{Au}(\mathrm{C} \equiv \mathrm{CPh})\left(\mathrm{PPh}_{3}\right)\right],{ }^{[31]}$ $[\mathrm{AuCl}(\mathrm{tht})],{ }^{[32]}$ and $\left[\mathrm{AuCl}\left(\mathrm{PPh}_{3}\right)\right]^{[33]}$ were synthesized as reported before. All other chemicals and reagents were commercially available and used without further purification.

Typical optimized procedure for the obtention of propargylamines 7 and 8 . To a solution of $2 \mathrm{mmol}$ of amines $5 \mathbf{a}-5 \mathbf{e}$ in $5 \mathrm{~mL}$ of $\mathrm{CH}_{2} \mathrm{Cl}_{2}$, the gold catalyst $\left(\mathbf{1}, \mathrm{K}\left[\mathrm{AuCl}_{4}\right], \mathbf{9}, \mathbf{1 0}\right.$, nano-12, [AuCl(tht)], $\left[\mathrm{AuCl}\left(\mathrm{PPh}_{3}\right)\right]$ or $\left.\left[\mathrm{Au}(\mathrm{C} \equiv \mathrm{CPh})\left(\mathrm{PPh}_{3}\right)\right], 5 \mathrm{~mol} \%\right)$ is added The corresponding alkyne (6a-d, $2 \mathrm{mmol})$ is subsequently added to the resulting mixture. The mixture is allowed to stir at $50^{\circ} \mathrm{C}$ during $24 \mathrm{~h}$. Subsequent filtration through celite and complete removal of the solvent gives crude mixtures that afford the final products after purification by column chromatography on silica gel. Details of the purifications for the different propargylamines as well as spectroscopic data and selected spectra are provided in the supporting material section.

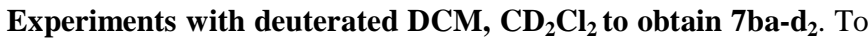
a solution of $2 \mathrm{mmol}$ of $\mathrm{Bu}_{2} \mathrm{NH}(\mathbf{5 a})$ in $5 \mathrm{~mL}$ of $\mathrm{CDCl}_{2}, \mathrm{~K}\left[\mathrm{AuCl}_{4}\right]$ is added ( $5 \mathrm{~mol} \%)$. Then phenylacetylene $(\mathbf{6} \mathbf{b}, 2 \mathrm{mmol})$ is added to the resulting mixture which is allowed to stir at $50^{\circ} \mathrm{C}$ during $24 \mathrm{~h}$. Subsequent filtration through celite and complete removal of the solvent gave a crude mixture that affords pure $\mathbf{7 b a - \mathbf { d } _ { 2 }}$ after purification by column chromatography on silica gel. Eluents nhexane/AcOEt (95:5). Yield: $60 \% \cdot \mathrm{C}_{17} \mathrm{H}_{23} \mathrm{D}_{2} \mathrm{~N}$ (245.44). MS(ESI +): $246(100 \%)[\mathrm{M}]^{+}$. Spectra in figure 3 and SI.

Reaction with $\mathrm{CH}_{2} \mathrm{Br}_{2}$ to obtain $7 \mathrm{ba}$. To a solution of $2.4 \mathrm{mmol}$ of $\mathrm{Bu}_{2} \mathrm{NH}(\mathbf{5 a})$ in $5 \mathrm{~mL}$ of $\mathrm{CH}_{2} \mathrm{Br}_{2}, \mathrm{~K}\left[\mathrm{AuCl}_{4}\right](5 \mathrm{~mol} \%)$ is added and then phenylacetylene $(\mathbf{6} \mathbf{b}, 2 \mathrm{mmol})$ is added. The resulting mixture 
is allowed to stir at $50^{\circ} \mathrm{C}$ during $24 \mathrm{~h}$. Subsequent filtration through celite and complete removal of the solvent gives a crude mixture that affords final product $7 \mathrm{ba}$ after purification by column chromatography on silica gel. Eluents n-hexane/AcOEt (95:5). Yield: $73 \%$. NMR spectra in SI.

\section{Gold-catalyzed cross-coupling reaction of $\mathrm{Bu}_{2} \mathrm{NH}(5 \mathrm{~b})$ with two} different alkynes (trimethylsilylacetylene $6 \mathrm{~d}$ and phenylacetylene 6a) in DCM. To a solution of $3.1 \mathrm{mmol}$ of $\mathrm{Bu}_{2} \mathrm{NH}$ (5a) in $5 \mathrm{~mL}$ of $\mathrm{CH}_{2} \mathrm{Br}_{2}, \mathrm{~K}\left[\mathrm{AuCl}_{4}\right](5 \mathrm{~mol} \%)$ is added and then phenylacetylene $(6 \mathbf{6}, 1.6 \mathrm{mmol})$ and trimethylsilylacetylene (6d, $1.6 \mathrm{mmol}$ ) are added as well. The resulting mixture is allowed to stir at $50^{\circ} \mathrm{C}$ during $24 \mathrm{~h}$. Subsequent filtration through celite and complete removal of the solvent gives a crude mixture that affords products $7 \mathbf{b a}, \mathbf{7 b d}, \mathbf{8 b d}$ and $\mathbf{1 3}$ after purification by column chromatography on silica gel. Eluents n-hexane/AcOEt (80:20).

Experiments with ${ }^{13} \mathrm{C}$ enriched trimethylsilylacetylene ${ }^{13} \mathrm{C}-6 \mathrm{~d}$ to obtain ${ }^{13} \mathbf{C - 8 b d}$. To a solution of $1 \mathrm{mmol}$ of $\mathrm{Bu}_{2} \mathrm{NH}(\mathbf{5 a})$ in $5 \mathrm{~mL}$ of $\mathrm{CH}_{2} \mathrm{Br}_{2}, \mathrm{~K}\left[\mathrm{AuCl}_{4}\right](5 \mathrm{~mol} \%)$ is added and then $1 \mathrm{mmol}$ of ${ }^{13} \mathrm{C}$ enriched trimethylsilylacetylene is added. The resulting mixture is allowed to stir at $50^{\circ} \mathrm{C}$ during $24 \mathrm{~h}$. Subsequent filtration through celite and complete removal of the solvent gives a crude mixture of products ${ }^{13} \mathbf{C}-7 \mathbf{b d}$ and ${ }^{13} \mathbf{C - 8 b d}$.

Synthesis of $\left[\mathrm{Au}\left(\mathrm{C}_{6} \mathrm{H}_{4}\left(\mathrm{PPh}_{2}=\mathrm{NPh}\right)-2\right) \mathrm{Cl}\left(\mathrm{PPh}_{3}\right)\right] \mathrm{ClO}_{4}$ (9). To a solution of orthoaurated complex $\mathbf{1}(0.201 \mathrm{~g}, 0.32 \mathrm{mmol})$ in dry THF $(20 \mathrm{~mL}) \mathrm{AgClO}_{4}(0.074 \mathrm{~g}, 0.36 \mathrm{mmol})$ is added. The resulting suspension is stirred for $30 \mathrm{~min}$ at room temperature with exclusion of light, and then filtered through a Celite pad to remove the insoluble $\mathrm{AgCl}$ formed. The freshly prepared solution is treated with $\mathrm{PPh}_{3}(0.085 \mathrm{~g}, 0.32 \mathrm{mmol})$ and stirred for $2 \mathrm{~h}$ at room temperature. The solvent is subsequently evaporated to a small volume and the residue treated with $\mathrm{Et}_{2} \mathrm{O}(20 \mathrm{~mL})$. Further stirring precipitates 9 as an orange solid that is filtered and vacuum-dried. Obtained: $0.193 \mathrm{~g}$ (63.1\% yield). Anal. Calc. for $\left[\mathrm{C}_{42} \mathrm{H}_{34} \mathrm{AuCl}_{2} \mathrm{NO}_{4} \mathrm{P}_{2}\right]$ (946.54): $\mathrm{C}$, 53.29; H, 3.62; N, 1.48. Found: C, 53.09; H, 3.45; N, 1.21. IR: 1277 $\left(v_{\mathrm{P}=\mathrm{N}}\right) \mathrm{cm}^{-1}$. MS (MALDI +): $846(100 \%)\left[\mathrm{M}-\mathrm{ClO}_{4}\right]^{+} .{ }^{31} \mathrm{P}\left\{{ }^{1} \mathrm{H}\right\}$ NMR $\left(\mathrm{CDCl}_{3}\right): \delta=40.46\left(\mathrm{PPh}_{3}\right), 60.09\left(\mathrm{PPh}_{2}\right) .{ }^{1} \mathrm{H} \mathrm{NMR}\left(\mathrm{CDCl}_{3}\right): \delta$ $=6.91-7.00\left(\mathrm{~m}, 5 \mathrm{H}, \mathrm{H}_{\mathrm{o}}+\mathrm{H}_{\mathrm{p}}, \mathrm{NPh} \mathrm{H}_{5}+\mathrm{H}_{6}, \mathrm{C}_{6} \mathrm{H}_{4}\right), 7.09\left(\mathrm{t}, 2 \mathrm{H}, \mathrm{H}_{\mathrm{m}}\right.$, $\left.\mathrm{NPh},{ }^{3} \mathrm{~J}_{\mathrm{HH}}=7.1\right)$, 7.29-7.34 (m, $\left.2 \mathrm{H}, \mathrm{H}_{3}+\mathrm{H}_{4}, \mathrm{C}_{6} \mathrm{H}_{4}\right), 7.54(\mathrm{~m}, 6 \mathrm{H}$, $\left.\mathrm{H}_{\mathrm{m}}, \mathrm{PPh}_{3}\right), 7.60-7.70\left(\mathrm{~m}, 13 \mathrm{H}, \mathrm{H}_{\mathrm{m}}, \mathrm{PPh}_{2}+\mathrm{H}_{\mathrm{p}}+\mathrm{H}_{\mathrm{o}}, \mathrm{PPh}_{3}\right), 7.77-7.85$ $\left(\mathrm{m}, 6 \mathrm{H}, \mathrm{H}_{\mathrm{p}}+\mathrm{H}_{\mathrm{o}}, \mathrm{PPh}_{2}\right) \cdot{ }^{13} \mathrm{C}\left\{{ }^{1} \mathrm{H}\right\} \mathrm{NMR}\left(\mathrm{CDCl}_{3}\right): \delta=123.94\left(\mathrm{~d}, \mathrm{C}_{\mathrm{i}}\right.$, $\left.\mathrm{PPh}_{3},{ }^{1} \mathrm{~J}_{\mathrm{PC}}=67.7\right), 124.41\left(\mathrm{~d}, \mathrm{C}_{\mathrm{i}}, \mathrm{PPh}_{2},{ }^{1} \mathrm{~J}_{\mathrm{PC}}=93.3\right), 125.86\left(\mathrm{~s}, \mathrm{C}_{\mathrm{p}}\right.$, $\mathrm{NPh}), 128.43\left(\mathrm{~s}, \mathrm{C}_{\mathrm{m}}, \mathrm{NPh}\right), 129.02\left(\mathrm{C}_{\mathrm{o}}, \mathrm{NPh}+\mathrm{C}_{4}+\mathrm{C}_{5}, \mathrm{C}_{6} \mathrm{H}_{4}\right.$ overlapped), $129.58\left(\mathrm{~d}, \mathrm{C}_{\mathrm{m}}, \mathrm{PPh}_{3},{ }^{3} \mathrm{~J}_{\mathrm{PC}}=12.6\right), 130.01\left(\mathrm{~d}, \mathrm{C}_{\mathrm{m}}, \mathrm{PPh}_{2}\right.$, $\left.{ }^{3} \mathrm{~J}_{\mathrm{PC}}=12.7\right), 131.46\left(\mathrm{~d}, \mathrm{C}_{3}, \mathrm{C}_{6} \mathrm{H}_{4},{ }^{2} \mathrm{~J}_{\mathrm{PC}}=17.6\right), 133.55\left(\mathrm{~d}, \mathrm{C}_{\mathrm{o}}, \mathrm{PPh}_{2}\right.$, $\left.{ }^{2} \mathrm{~J}_{\mathrm{PC}}=10.7\right), 133.88\left(\mathrm{~d}, \mathrm{C}_{\mathrm{p}}, \mathrm{PPh}_{3}, \mathrm{~J}_{\mathrm{PC}}=3.1+\mathrm{C}_{6}, \mathrm{C}_{6} \mathrm{H}_{4}\right.$ overlapped $)$, $134.97\left(\mathrm{~d}, \mathrm{C}_{\mathrm{p}}, \mathrm{PPh}_{2},{ }^{4} \mathrm{~J}_{\mathrm{PC}}=2.8\right), 135.13\left(\mathrm{~d}, \mathrm{C}_{\mathrm{o}}, \mathrm{PPh}_{3},{ }^{4} \mathrm{~J}_{\mathrm{PC}}=10.8\right)$, $136.08\left(\mathrm{~d}, \mathrm{C}_{2}, \mathrm{C}_{6} \mathrm{H}_{4},{ }^{1} \mathrm{~J}_{\mathrm{PC}}=126.1\right), 143.15\left(\mathrm{~d}, \mathrm{C}_{1}, \mathrm{NPh},{ }^{2} \mathrm{~J}_{\mathrm{PC}}=2.2\right)$, $151.57\left(\mathrm{~d}, \mathrm{C}_{1}, \mathrm{C}_{6} \mathrm{H}_{4},{ }^{2} \mathrm{~J}_{\mathrm{PC}}=14.8\right)$.

Synthesis of $\left[\mathrm{Au}\left(\mathrm{C}_{6} \mathrm{H}_{4}-\left(\mathrm{PPh}_{2}=\mathrm{NPh}\right)-2\right)(\right.$ dppe-P,P') $]\left(\mathrm{ClO}_{4}\right)_{2}$ (10). To a solution of $1(0.184 \mathrm{~g}, 0.30 \mathrm{mmol})$ in dry THF $(20 \mathrm{~mL})$ $\mathrm{AgClO}_{4}(0.135 \mathrm{~g}, 0.65 \mathrm{mmol})$ is added. The resulting suspension is stirred for $30 \mathrm{~min}$ with exclusion of light, and then filtered through a Celite pad to remove the insoluble $\mathrm{AgCl}$ formed. To the freshly prepared solution dppe $(0.118 \mathrm{~g}, 0.30 \mathrm{mmol})$ is added, and the resulting pale yellow solution is stirred at room temperature for $2 \mathrm{~h}$. After the reaction time the solvent is evaporated to small volume $(\approx$ $1 \mathrm{~mL})$ and $\mathrm{Et}_{2} \mathrm{O}(30 \mathrm{~mL})$ is added. By continuous stirring $\mathbf{1 0}$ is obtained as a yellow solid that is filtered and vacuum-dried. Obtained: $\quad 0.133$ g $\quad(39.2 \%$ yield). Anal. Calc. for $\left[\mathrm{C}_{50} \mathrm{H}_{43} \mathrm{AuCl}_{2} \mathrm{NO}_{8} \mathrm{P}_{3}\right]$ (1146.67): C, 52.37; H, 3.78; N, 1.22. Found: C, 51.91; H, 3.50; N, 1.05. IR: $1284\left(v_{\mathrm{P}=\mathrm{N}}\right) \mathrm{cm}^{-1}$. MS (MALDI +): $1046(95 \%)\left[\mathrm{M}_{-} \mathrm{ClO}_{4}\right]^{+} .{ }^{31} \mathrm{P}\left\{{ }^{1} \mathrm{H}\right\} \mathrm{NMR}\left(\mathrm{CDCl}_{3}\right): \delta=61.01\left(\mathrm{~d}, \mathrm{PPh}_{2}\right.$, $\left.{ }^{4} \mathrm{~J}_{\mathrm{PP}}=2.4\right), 64.75\left(\mathrm{~d}\right.$, dppe, $\left.{ }^{3} \mathrm{~J}_{\mathrm{PP}}=14.8\right), 72.38\left(\mathrm{dd}, \mathrm{dppe},{ }^{3} \mathrm{~J}_{\mathrm{PP}}=14.8\right.$, $\left.{ }^{4} \mathrm{~J}_{\mathrm{PP}}=2.4\right) .{ }^{1} \mathrm{H} \mathrm{NMR}\left(\mathrm{CDCl}_{3}\right): \delta=6.41\left(\mathrm{t}, 2 \mathrm{H}, \mathrm{H}_{\mathrm{m}}, \mathrm{NPh},{ }^{3} \mathrm{~J}_{\mathrm{HH}}=7.6\right)$, $6.55\left(\mathrm{t}, 1 \mathrm{H}, \mathrm{H}_{\mathrm{p}}, \mathrm{NPh},{ }^{3} \mathrm{~J}_{\mathrm{HH}}=7.3\right), 6.62\left(\mathrm{~d}, 2 \mathrm{H}, \mathrm{H}_{\mathrm{o}}, \mathrm{NPh},{ }^{3} \mathrm{~J}_{\mathrm{HH}}=7.6\right)$, $7.04\left(\mathrm{td}, 1 \mathrm{H}, \mathrm{H}_{4}, \mathrm{C}_{6} \mathrm{H}_{4},{ }^{4} \mathrm{~J}_{\mathrm{HP}}=3.0,{ }^{3} \mathrm{~J}_{\mathrm{HH}}=7.3\right), 7.23-7.31\left(\mathrm{~m}, 3 \mathrm{H}, \mathrm{H}_{3}\right.$ $\left.+\mathrm{H}_{5}+\mathrm{H}_{6}, \mathrm{C}_{6} \mathrm{H}_{4}\right), 7.46-7.52\left(\mathrm{~m}, 10 \mathrm{H}, \mathrm{H}_{\mathrm{m}}+\mathrm{H}_{\mathrm{p}}+\mathrm{H}_{\mathrm{o}}, \mathrm{Ph}_{2}\right.$-dppe), 7.59-7.63 (m, $4 \mathrm{H}, \mathrm{H}_{\mathrm{m}}, \mathrm{PPh}_{2}-\mathrm{C}_{6} \mathrm{H}_{4}$ ), 7.67-7.75 (m, $12 \mathrm{H}, \mathrm{H}_{\mathrm{m}}+\mathrm{H}_{\mathrm{p}}$, $\mathrm{Ph}_{2}$-dppe $+\mathrm{H}_{\mathrm{p}}+\mathrm{H}_{\mathrm{o}}, \mathrm{PPh}_{2}-\mathrm{C}_{6} \mathrm{H}_{4}$ ), 7.99-8.05 (m, 4H, $\mathrm{H}_{\mathrm{o}}, \mathrm{Ph}_{2}$-dppe). ${ }^{13} \mathrm{C}\left\{{ }^{1} \mathrm{H}\right\} \operatorname{NMR}\left(\mathrm{CDCl}_{3}\right): \delta=28.89\left(\mathrm{~d}, \mathrm{CH}_{2}\right.$, dppe, $\left.{ }^{1} \mathrm{~J}_{\mathrm{PC}}=36.8\right), 30.55$ (d, $\mathrm{CH}_{2}$, dppe, $\left.{ }^{1} \mathrm{~J}_{\mathrm{PC}}=41.6\right), 120.70\left(\mathrm{~d}, \mathrm{C}_{\mathrm{i}}, \mathrm{PPh}_{2}\right.$-dppe, $\left.{ }^{1} \mathrm{~J}_{\mathrm{PC}}=63.8\right)$, $121.77\left(\mathrm{~d}, \mathrm{C}_{\mathrm{i}}, \mathrm{PPh}_{2}\right.$-dppe, $\left.{ }^{1} \mathrm{~J}_{\mathrm{PC}}=54.0\right), 123.84\left(\mathrm{~d}, \mathrm{C}_{\mathrm{i}}, \mathrm{PPh}_{2}-\mathrm{C}_{6} \mathrm{H}_{4}\right.$, $\left.{ }^{1} \mathrm{~J}_{\mathrm{PC}}=94.0\right), 126.04\left(\mathrm{~s}, \mathrm{C}_{\mathrm{p}}, \mathrm{NPh}\right), 128.56\left(\mathrm{~s}, \mathrm{C}_{\mathrm{m}}, \mathrm{NPh}\right), 128.88\left(\mathrm{~d}, \mathrm{C}_{\mathrm{o}}\right.$, $\left.\mathrm{NPh},{ }^{3} \mathrm{~J}_{\mathrm{PC}}=4.5\right), 129.91\left(\mathrm{~d}, \mathrm{C}_{\mathrm{m}}, \mathrm{PPh}_{2}\right.$-dppe, $\left.{ }^{3} \mathrm{~J}_{\mathrm{PC}}=12.7\right), 130.27(\mathrm{~d}$, $\left.\mathrm{C}_{\mathrm{m}}, \mathrm{PPh}_{2}-\mathrm{C}_{6} \mathrm{H}_{4},{ }^{3} \mathrm{~J}_{\mathrm{PC}}=11.9\right), 130.99\left(\mathrm{~d}, \mathrm{C}_{\mathrm{m}}, \mathrm{PPh}_{2}\right.$-dppe, $\left.{ }^{3} \mathrm{~J}_{\mathrm{PC}}=12.6\right)$, $131.26\left(\mathrm{~s}, \mathrm{C}_{6} \mathrm{H}_{4}\right), 133.45-133.83\left(\mathrm{C}_{\mathrm{p}}, \mathrm{PPh}_{2}\right.$-dppe $+\mathrm{C}_{\mathrm{p}}, \mathrm{PPh}_{2}-\mathrm{C}_{6} \mathrm{H}_{4}+$ $\mathrm{C}_{\mathrm{p}}, \mathrm{PPh}_{2}$-dppe $+\mathrm{C}_{\mathrm{o}}, \mathrm{PPh}_{2}$-dppe overlapped $), 134.21\left(\mathrm{~d}, \mathrm{C}_{\mathrm{o}}, \mathrm{PPh}_{2}\right.$ dppe, $\left.{ }^{2} \mathrm{~J}_{\mathrm{PC}}=11.4\right), 134.75\left(\mathrm{~d}, \mathrm{C}_{\mathrm{o}}, \mathrm{PPh}_{2}-\mathrm{C}_{6} \mathrm{H}_{4},{ }^{2} \mathrm{~J}_{\mathrm{PC}}=28.4+\mathrm{C}_{4}, \mathrm{C}_{6} \mathrm{H}_{4}\right.$ overlapped), $136.97\left(\mathrm{C}_{6} \mathrm{H}_{4}\right), 137.19\left(\mathrm{C}_{6} \mathrm{H}_{4}\right)$. Signals due to $\mathrm{C}_{1}$, $(\mathrm{NPh})$ and $\mathrm{C}_{1}, \mathrm{C}_{2}\left(\mathrm{C}_{6} \mathrm{H}_{4}\right)$ were not observed, in spite of long time accumulation trials.

Preparation, X-ray and TEM Characterization of gold nanoparticles nano-11. A $1 \mathrm{~mL}$ aliquot of nano-11, generated from a solution of ${ }^{\mathrm{n}} \mathrm{Bu}_{2} \mathrm{NH}(2 \mathrm{mmol})$ in $5 \mathrm{~mL}$ of $\mathrm{CH}_{2} \mathrm{Cl}$ with $\mathrm{K}\left[\mathrm{AuCl}_{4}\right]$ (5 $\mathrm{mol} \%$ ), (after stirring for $5 \mathrm{~min}$ at r.t.) was applied onto a glow discharged carbon coated copper grid and blotted. The specimen was imaged with a JEOL-2000FXII high-resolution transmission electron microscope (point to point resolution $0.28 \mathrm{~nm}$ ) and images were recorded on a Gatan MSC-794 camera, using the Digital Micrograph software (from Gatan). Step-scanned powder diffraction pattern of nano-11 was collected at room temperature using a Siemens D500/501 diffractometer with a $\mathrm{Cu}$ X-ray tube. The 
diffractometer was operated at $30 \mathrm{~mA}$ and $35 \mathrm{kV}$ and a graphite monochromator was used to select the $\mathrm{Cu}$ Ka1,2 radiation. Data were collected from $5^{\circ}$ up $80^{\circ}$ with a stepsize of $0.03^{\circ}$ and a counting rate of $2 \mathrm{~s} / \mathrm{step}$.

Preparation and TEM Characterization of gold nanoparticles 22. A $1 \mathrm{~mL}$ aliquot of $\mathbf{2 2}$ generated from a solution of ${ }^{\mathrm{n}} \mathrm{Bu}_{2} \mathrm{NH}$ (2 mmol) in $5 \mathrm{~mL}$ of $\mathrm{CH}_{2} \mathrm{Cl}$ with [ $\left.\mathrm{AuCl}(\mathrm{tht})\right]$ ( $5 \mathrm{~mol} \%$ ) (after stirring for 5 min at r.t.) was applied onto a glow discharged carbon coated copper grid and blotted. The specimen was imaged with a JEOL2000FXII high-resolution transmission electron microscope (point to point resolution $0.28 \mathrm{~nm}$ ) and images were recorded on a Gatan MSC-794 camera, using the Digital Micrograph software (from Gatan).

X-ray Photoelectron Spectroscopy. XPS measurements of nano-14 prepared by reduction with $\mathrm{Bu}_{2} \mathrm{NH}(5 \mathrm{~b})$ of $\mathrm{K}\left[\mathrm{AuCl}_{4}\right]$, were taken using a Kratos AXIS Ultra DLD (Kratos Tech.) spectrometer. Samples were prepared under the cover of Ar gas and placed in a vacuum before measurement. While collecting the survey scans the following parameters were used: $\mathrm{AlK} \alpha$ monochromatic excitation source $(1486.6 \mathrm{eV})$ working at $15 \mathrm{KV}$ and $10 \mathrm{~mA}$, pass energy $=120$ $\mathrm{eV}$. To confirm the oxidation state of the various gold species, highresolution scans were also taken using a pass energy of $20 \mathrm{eV}$.

\section{Acknowledgements}

Funding from MICINN (CTQ2008-01784, Spain) and Brooklyn College (US) is gratefully acknowledged. D. A. thanks DGA (Spain) for a Ph. D. grant. The authors also thank Prof. Fernando López Ortiz (Universidad de Almeria, Spain) for his stimulating and constructive comments and Prof. Jesús Santamaría and Dr. Silvia Irusta (INA, Universidad de Zaragoza) for facilitating the XPS measurements.

[1] Two relevant examples: a) Y. Yamamoto, H. Hayashi, T. Saigoku, T.; H. Nishiyama, J. Am. Chem. Soc. 2005, 127, 10804-10805. b) B. Jiang, M. Xu, Angew. Chem., Int. Ed. 2004, 43, 2543-2546.

[2] Z. Li, C.-J. Li. J. Am. Chem. Soc. 2004, 126, 11810-11811.

[3] Copper: a) M. Miura, M. Enna, K. Okuro, M. Nomura. J. Org. Chem. 1995, 60, 4999-5004. b) R. Fassler, D.E. Frantz, E.M. Carreira. J. Am. Chem. Soc. 1999 121, 11245-11246. c) C. Fischer, E.M. Carreira. Org. Lett. 2001, 3, 4319-4321. d) C. Koradin, N. Gommermann, K. Polborn, P. Knochel. Chem. Eur. J. 2003, 9 , 2797-2811. e) C. Koradin, K, Polborn, P. Knochel. Angew. Chem. Int. Ed. 2002, 41, 2535-2538. f) R. Fassler, D.E. Frantz, J. Oetiker, E.M. Carreira. Angew. Chem. Int. Ed. 2002, 41, 3054-3056. g) C.J. Li, C.M. Wei. Chem. Commun 2002, 268-269. h) C. Wei, C.-J. Li. J. Am. Chem. Soc. 2002, 124, 5638-5639. i) C.M. Wei, C.J. Li. Green Chem. 2002, 4, 39-41. j) L. Shei, Y.-Q. Tu, M. Wang, F.-M. Zhang, C.-A. Fan. Org. Lett. 2004, 6, 1001-1003. k) B.M. Choudary, C. Sridhar, M.L. Kantam, B. Sreedhar. Tetrahedron Lett. 2004, 45, 7319-7321. 1) L.W. Bieber, M.F. da Silva. Tetrahedron Lett. 2004, 45, 8281-8283. m) N Gommermann, P. Knochel. Chem. Commun. 2004, 2324-2325.

[4] Silver and gold: a) C. Wei, C.-J. Li. J. Am. Chem. Soc. 2003, 125, 9584-9585. b) C. Wei, Z. Li, C.-J. Li. Org. Lett. 2003, 5, 4473-4476. c) Z. Li, C. Wei, L. Chen, R.S. Varma, C.-J. Li. Tetrahedron Lett. 2004, 45, 2443-2446. d) M.L. Kantam, B.V. Prakash, C.R.V. Reddy, B. Sreedhar. Synlett, 2005, 2329-2332. e) V.K.-Y. Lo, Y. Liu, M.-K. Wong, C.-M. Che. Org. Lett. 2006, 8, 1529-1532. f) F. Xiao,
Y. Chen, Y. Liu, J. Wang. Tetrahedron, 2008, 64, 2755-2761. g) P. Oña-Burgos, I. Fernández, L. Roces, L. Torre Fernández, S. García-Granda, F. López Ortiz. Organometallics, 2009, 28, 1739-1747.

[5] a) X. Zhang, A. Corma, Angew. Chem. Int. Ed. 2008, 47, 4358-4361; b) V. K.-Y. Lo, K. K.-Y. Kung, M.-K. Wong, C.-M. Che, J. Organomet. Chem. 2009, 694 , 583-591. c) B. Ellie, C. Levine, I. Belandia-Ubarretxena, A. Varela-Ramírez, R. J. Aguilera, R. Ovalle, M. Contel, Eur. J. Inorg. Chem. 2009, 3421-3430.

[6] M. Kidwai, V. Bansal, A. Kumar, S. Mozumdar, Green Chem. 2007, 9, 742-745.

[7] X. Bei, A. Hagemeyer, A. Volpe, R. Saxton, H. Turner, A. S. Guram, J. Org. Chem. 2004, 69, 8626-8632 and references cited therein.

[8] P. Suisse, S. Pellegrini, Y. Castanet, A. Mortreux, S. Lecoulier, J. Chem. Soc., Chem. Commun. 1995, 847-848.

[9] Selected examples: a) T. B. Marder, W. C. Fultz, J. C. Calabrese, R. L. Harlow, D. Milstein, J. Chem. Soc., Chem. Commun. 1987, 1543-1545. b) J.-J. Bruner, X. Couillens, J. C. Daran, O. Diallo, C. Lepetit, D. Neibecker, Eur. J. Inorg. Chem. 1998, 349-353 and references cited therein.

[10] C. Hunt, F. R. Fronczek, D. R. Billodeaux, G. G. Stanley, Inorg. Chem. 2001, 40, 5192-5198.

[11] D. Rondon, J. Delbeau, X.-D. He, S. Sabo-Etienne, B. Chaudret, J. Chem. Soc., Dalton Trans. 1994, 1895-1901.

[12] H. Suzuki, T. Kakigano, M. Igarashi, M. Tanaka, Y. Moro-oka, J. Chem. Soc., Chem. Commun. 1991, 283-285 and references cited therein.

[13] P. Jandik, U. Schubert, H. Schmidbaur, Angew. Chem..1982, 94, 74-75.

[14] K.-I. Sugawara, S. Hikichi, M. Akita, Chem. Lett. 2001, 1094-1095.

[15] T.-H. Yan, C.-C. Tsai, C.-T. Chien, C.-C. Cho, P.-C. Huang, Org. Lett. 2004, 6 , 4961-4963.

[16] K. J. Doyle, H. Tran, M. Baldoni-Olivencia, M. Karabulut, P. E. Hoggard, Inorg. Chem. 2008, 47, 7029-7034 and references cited therein.

[17] a) M. Contel, S. Sanz, R. Casado, M. Laguna, P. Romero, Chemiedozententagung 2004; Dortmund, Germany; Talk A23. b) M. Contel, S. Sanz, M Laguna, P. Romero, XXII Reunión GEQO 2004 Ciudad Real (Spain). Pannel PC17. c) S. Sanz, PhD, University of Zaragoza, 2007.

[18] Some representative recent reviews on gold catalysis: a) A.S.K. Hashmi, G.J. Hutchings, Angew. Chem. 2006, 118, 8064-8105; Angew. Chem. Int, Ed. 2006, 45, 7896-7936; b) A. Furstner, P.W. Davis, Angew. Chem. 2007, 119, 34783519; Angew. Chem. Int. Ed. 2007, 46, 3410-3449; c) D.J. Gorin, F.D. Toste, Nature 2007, 107, 3180-3211; e) A. Arcadi, Chem. Rev. 2008, 108, 3266-3325; f) E. Jiménez-Núñez, A.M. Echavarren, Chem. Rev. 2008, 108, 3326-3350; g) Z.G. Li, C. Brouwer, C. He, Chem. Rev. 2008, 108, 3239-3265.

[19] a) D. Aguilar, M. Contel, R. Navarro, E. P. Urriolabeitia, Organometallics 2007, 26, 4604-4611. b) D. Aguilar, M. Contel, R. Navarro, T. Soler, E. P. Urriolabeitia, J. Organomet. Chem. 2009, 694, 486-493. c) N. Shaik, A. Martínez, I. Augustin, H. Giovinazzo, A. Varela-Ramírez, M. Sanaú, R. J. Aguilera, M. Contel, M. Inorg. Chem. 2009, 48, 1577-1587.

[20] a) H. Staudinger, J. J. Meyer, Helv. Chim. Acta 1919, 2, 635-646. b) S. Bittner, M. Pomerantz, Y. Assaf, P. Krief, S. Xi, M. K. Witczak, J. Org. Chem 1988, 53, 1-5 and refs. therein.

[21] L. Yangu, F. Peng-Fei, J. M. Tobin, Organometallics 1994, 13, 439-440.

[22] a) Y. Fukuda, K. Utimoto, Synth. 1991, 975-978. b) Y. Fukuda, K. Utimoto, H. Nozaki, Heterocycles, 1987, 25, 297-300.

[23] J. D. Rose, B. C. L. Weedon, J. Chem. Soc. 1949, 780-782.

[24] a) D.V. Leff, L. Brandt, J.R. Health, Langmuir 1996, 12, 4723-4730; b) H. Hiramatsu, F.E. Osterloch, Chem. Mat. 2004, 16, 2509-2511: c) C. Subramaniam, R.T. Tom, T. Pradeep, J. Nanopart. Res. 2005, 7, 209-217. d) M. Aslam, L. Fu, M. Su, K. Vijayamohanan, V.P. Dravid, J, Mat. Chem. 2004, 14, 1795-1797.

[25] X. Lu; H.-Y. Tuan, B.A. Korgel, Y. Xia. Chem. A Eur. J.., 2008, 14, 1584-1591.

[26] M. Brust, M. Walker, D. J. Bethell, D. J. Schiffrin, R. Whyman. Chem. Commun. 1994, 801-802.

[27] J. Vicente, M.-T. Chicote, M. M. Alvarez-Falco, Organometallics, 2005, 24, 5956-5963.

[28] H. H. Murray, J. P. Fackler Jr. A. M. Mazany, Organometallics, 1984, 3, 13101311.

[29] M. Contel, D. Nobel, G. van Koten, A. L. Spek, Organometallics, 2000, 19, 3288-3295.

[30] a) S. Komiys, S. Ozaki, A. Shibue. J. Chem. Soc., Chem. Commun. 1986, $1555-$ 1556. b) O. Schuster, H. Schmidbaur. Organometallics, 2005, 24, 2289-2296.

[31] R. J. Cross, M. F. Davidson, J. Chem. Soc., Dalton Trans. 1986, 411-415.

[32] R. Usón, A. Laguna, M. Laguna, Inorg. Synth., 1989, 26, 85-91.

[33] R. Usón, A. Laguna, J. Vicente, J. Organomet. Chem. 1977, 131, 471-475. 


\section{Entry for the Table of Contents}

\section{Layout 2:}

Propargylamines by double C-Cl activation

David Aguilar, Maria Contel, * and Esteban P. Urriolabeitia* Page - Page

Mechanistic Insights into the One-Pot Synthesis of Propargylamines from Terminal Alkynes and Amines in Chlorinated Solvents Catalyzed by Gold Compounds and Nanoparticles

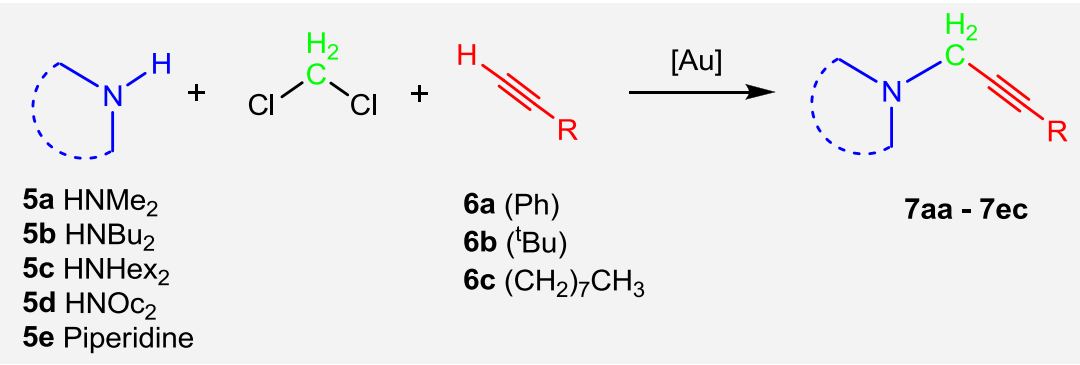

Propargylamines can be obtained The use of dichloromethane from amines and terminal alkynes in allows for the activation of two Cchlorinated solvents by catalysis $\mathrm{Cl}$ bonds and a clean transfer of with gold compounds and the methylene fragment to the nanoparticles under mild reaction final product. conditions. 


\title{
Mechanistic Insights into the One-Pot Synthesis of Propargylamines from Terminal Alkynes and Amines in Chlorinated Solvents Catalyzed by Gold Compounds and Nanoparticles
}

\author{
David Aguilar, ${ }^{\mathrm{a}}$ María Contel, ${ }^{\mathrm{b}^{*}}$ and Esteban P. Urriolabeitia ${ }^{\mathrm{a}^{*}}$
}

${ }^{a}$ Departamento de Compuestos Organometálicos, Instituto de Ciencia de Materiales de Aragón (CSIC-UZ), Pedro Cerbuna 12, 50009 Zaragoza (Spain). ${ }^{\mathrm{b}}$ Chemistry Department, Brooklyn College and the Graduate Center, The City University of New York, New York 11210,

*Email: esteban@unizar.es; mariacontel@brooklyn.cuny.edu

\section{SUPPORTING INFORMATION}

\section{Intramolecular Hydroamination Reactions}

All the reactions were carried out at $50{ }^{\circ} \mathrm{C}$ in a Kontex tube. To a solution of alkenylamine $3(0.66 \mathrm{mmol})$ in $15 \mathrm{~mL}$ of dry $\mathrm{CH}_{3} \mathrm{CN}$ the catalyst $(5 \mathrm{~mol} \%)$ is added $\left(\mathrm{Na}\left[\mathrm{AuCl}_{4}\right], \mathbf{1}\right.$, or $\mathbf{2}$, see table 1 in manuscript). The reaction mixture is refluxed during 2 hours and then the solvent is completely removed. The obtained residue is dissolved in $20 \mathrm{~mL}$ of $\mathrm{Et}_{2} \mathrm{O}$ and extracted with a saturated solution of $\mathrm{NH}_{4} \mathrm{Cl}(3 \times 15 \mathrm{~mL})$. The organic phase is dried with anhydrous $\mathrm{MgSO}_{4}$ and dried under vacuum. Conversions shown in table 1 were obtained by ${ }^{1} \mathrm{H}$ NMR analysis of isolated product 4 . 
$\mathrm{C}_{8} \mathrm{H}_{17} \mathrm{NSi}$. Anal. Calc. for $\mathrm{C}_{8} \mathrm{H}_{17} \mathrm{NSi}$ (155.31) C, 61.87; H, 11.03; N, 9.02; Found: $\mathrm{C}, 60.98 ; \mathrm{H}, 10.57$; N, 8.75. MS(ESI +): $155(75 \%)[M]^{+} .{ }^{1} \mathrm{H}$ NMR (400 MHz, $\left.\mathrm{CDCl}_{3}\right):$ ä = $0.08\left(\mathrm{~s}, 9 \mathrm{H}, \mathrm{SiMe}_{3}\right), 1.41(\mathrm{~s}$, 2H, $\left.\mathrm{CH}_{2}\right)$, 1.67-1.74 (m, 2H, $\left.\mathrm{CH}_{2}\right), 2.29\left(\mathrm{t}, 2 \mathrm{H}, \mathrm{CH}_{2},{ }^{3} \mathrm{~J}_{\mathrm{HH}}=6.9\right), 3.69\left(\mathrm{t}, 2 \mathrm{H}, \mathrm{CH}_{2},{ }^{3} \mathrm{~J}_{\mathrm{HH}}=6.1\right) .{ }^{13} \mathrm{C}\left\{{ }^{1} \mathrm{H}\right\}$ NMR (400 MHz, $\left.\mathrm{CDCl}_{3}\right)$ : $0.02\left(\mathrm{~s}, \mathrm{SiMe}_{3}\right), 16.10\left(\mathrm{~s}, \mathrm{CH}_{2}\right), 28.41\left(\mathrm{~s}, \mathrm{CH}_{2}\right), 30.16\left(\mathrm{~s}, \mathrm{CH}_{2}\right), 60.92$ (s, $\left.\mathrm{CH}_{2}\right)$.

\section{NMR ${ }^{1} \mathbf{H} 4$}

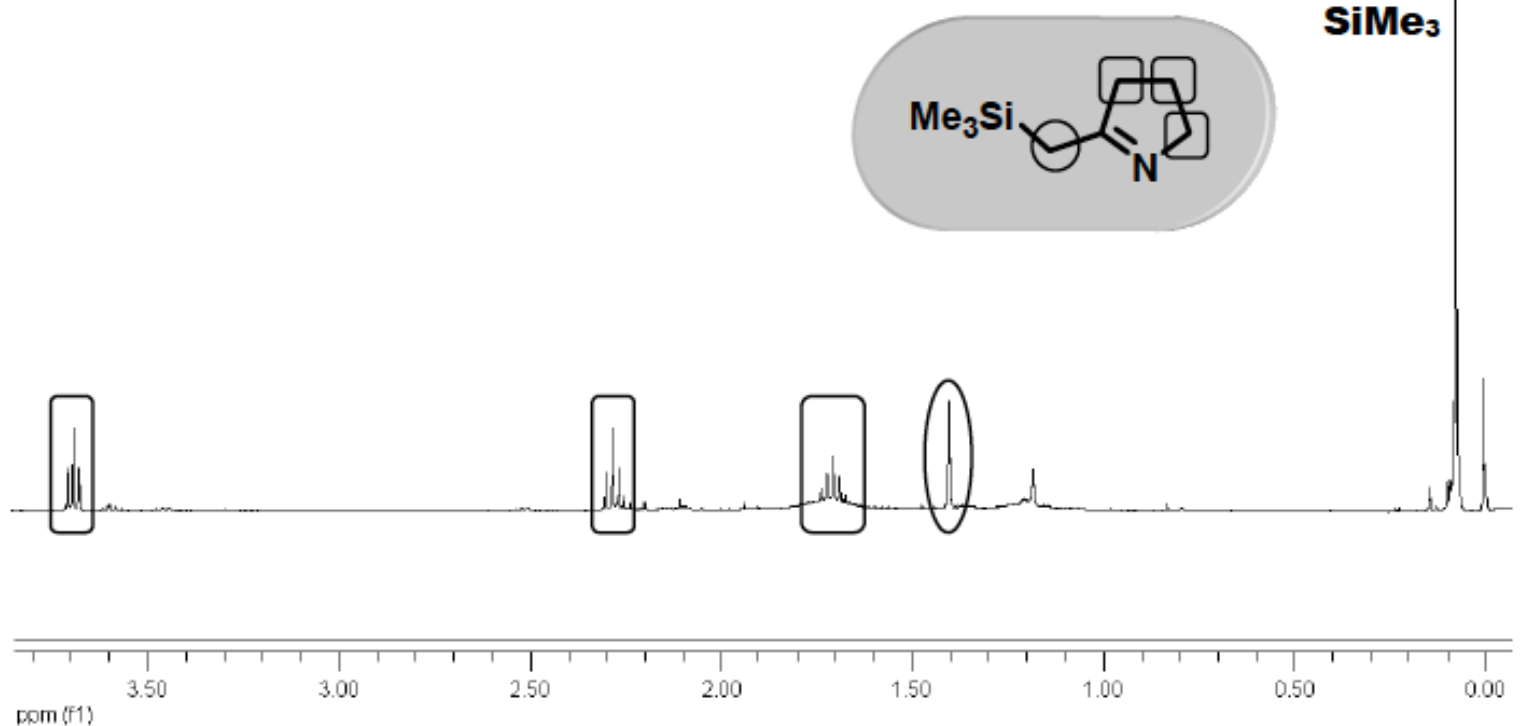

\section{$\mathrm{SiMe}_{3}$}

\section{Preparation and characterization of propargylamines 7 and 8 , selected ${ }^{1} \mathrm{H}$ and ${ }^{13} \mathrm{C}$ NMR spectra}

Typical optimized procedure for the obtention of propargylamines 7 and 8 :

To a solution of $2 \mathrm{mmol}$ of amines $\mathbf{5 a - 5 e}$ in $5 \mathrm{~mL}$ of $\mathrm{CH}_{2} \mathrm{Cl}_{2}$, the gold catalyst $\left(\mathbf{1}, \mathrm{K}\left[\mathrm{AuCl}_{4}\right], \mathbf{9}, \mathbf{1 0}\right.$, nano12, $[\mathrm{AuCl}(\mathrm{tht})],\left[\mathrm{AuCl}\left(\mathrm{PPh}_{3}\right)\right]$ or $\left.\left[\mathrm{Au}(\mathrm{C} \equiv \mathrm{CPh})\left(\mathrm{PPh}_{3}\right)\right], 5 \mathrm{~mol} \%\right)$ is added. The corresponding alkyne (6ad, $2 \mathrm{mmol}$ ) is subsequently added to the resulting mixture. The mixture is allowed to stir at $50^{\circ} \mathrm{C}$ during $24 \mathrm{~h}$. Subsequent filtration through celite and complete removal of the solvent gives crude mixtures that afford the final products after purification by column chromatography on silica gel. Details of the purifications for the different propargylamines as well as spectroscopic data and selected spectra are provided below. 
${ }_{7 \mathbf{a a}}^{\mathrm{Me}_{2} \mathrm{~N}} \overbrace{\mathrm{Ph}}$

$\mathrm{C}_{11} \mathrm{H}_{13} \mathrm{~N}(159.23)$; MS(ESI +): $160(55 \%)[\mathrm{M}]^{+} .{ }^{1} \mathrm{H}$ NMR $\left(400 \mathrm{MHz}, \mathrm{CDCl}_{3}\right): \delta=2.28\left(\mathrm{~s}, 6 \mathrm{H}, \mathrm{NCH}_{3}\right)$, 3.38 (s, 2H, $\left.\mathrm{CH}_{2}-\mathrm{C} \equiv \mathrm{C}\right)$, 7.20-7.28 (m, 3H, $\left.\mathrm{H}_{\mathrm{p}}+\mathrm{H}_{\mathrm{m}}, \mathrm{Ph}\right)$, 7.34-7.44 (m, 2H, $\left.\mathrm{H}_{\mathrm{o}}, \mathrm{Ph}\right) .{ }^{13} \mathrm{C}\left\{{ }^{1} \mathrm{H}\right\}$ NMR (400

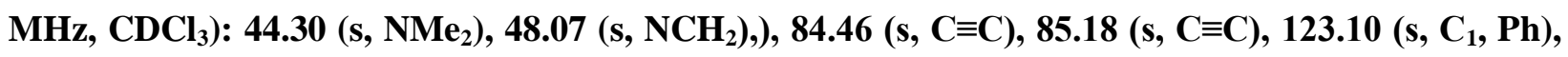
128.01 (s, $\left.\mathrm{C}_{\mathrm{p}}, \mathrm{Ph}\right), \mathbf{1 2 8 . 2 7}\left(\mathrm{s}, \mathrm{C}_{\mathrm{m}}, \mathrm{Ph}\right), \mathbf{1 3 1 . 7 1}\left(\mathrm{s}, \mathrm{C}_{\mathrm{o}}, \mathrm{Ph}\right)$.

NMR ${ }^{1}$ H 7aa

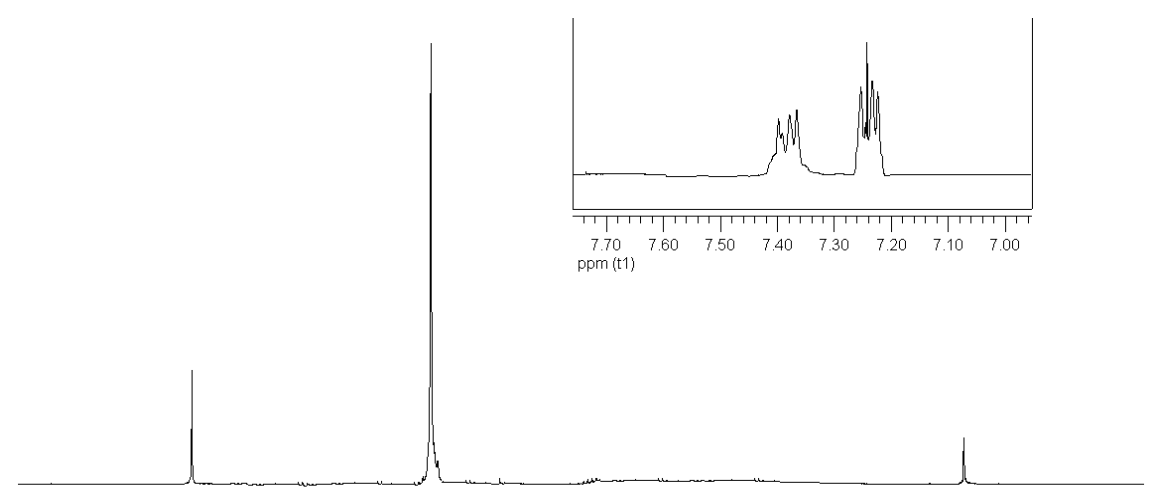

$\mathrm{NMR}{ }^{13} \mathrm{C}\left\{{ }^{1} \mathrm{H}\right\} \mathbf{7 a a}$

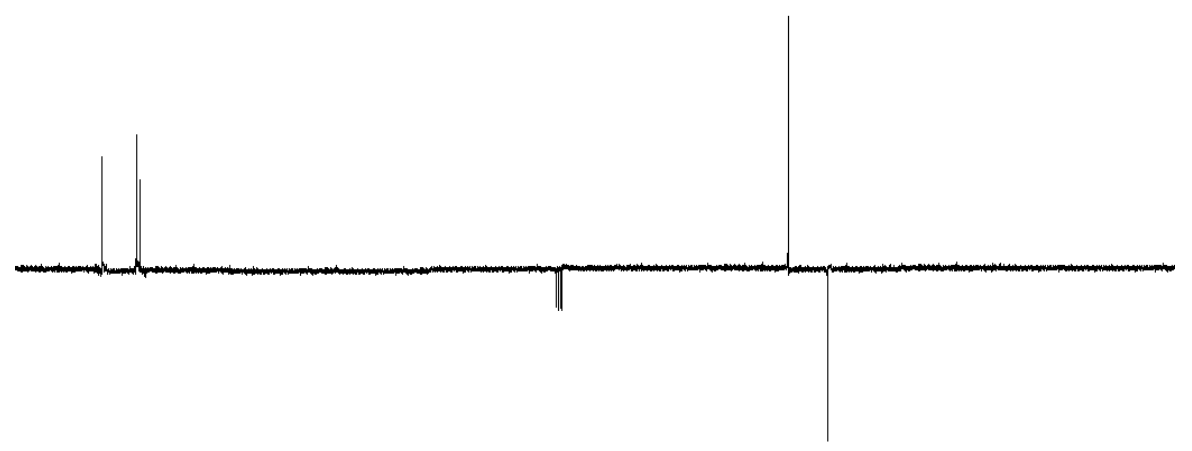


${ }_{7 a b} \mathrm{Me}_{2} \mathrm{~N} \curvearrowright\left(\mathrm{CH}_{3}\right)_{3}$

$\mathrm{C}_{8} \mathrm{H}_{17} \mathrm{~N}(127.23)$; MS(ESI +): $128(60 \%)[\mathrm{M}]^{+} .{ }^{1} \mathrm{H}$ NMR $\left(400 \mathrm{MHz}, \mathrm{CDCl}_{3}\right): \delta=1.28\left(\mathrm{~s}, 9 \mathrm{H},\left(\mathrm{CH}_{3}\right)_{3}\right)$, $2.28\left(\mathrm{~s}, 6 \mathrm{H}, \mathrm{NCH}_{3}\right), 3.40\left(\mathrm{~s}, 2 \mathrm{H}, \mathrm{CH}_{2}-\mathrm{C} \equiv \mathrm{C}\right) .{ }^{13} \mathrm{C}\left\{{ }^{1} \mathrm{H}\right\} \mathrm{NMR}\left(400 \mathrm{MHz}, \mathrm{CDCl}_{3}\right): 32.00\left(\mathrm{~s},\left(\mathrm{CH}_{3}\right)_{3}\right), 43.80$ $\left(\mathrm{s}, \mathrm{NMe}_{2}\right), 48.70\left(\mathrm{~s}, \mathrm{NCH}_{2}\right)(\mathrm{C} \equiv \mathrm{C}$ signal was not observed $)$.

\section{NMR ${ }^{1} \mathbf{H} 7 \mathbf{a b}$}

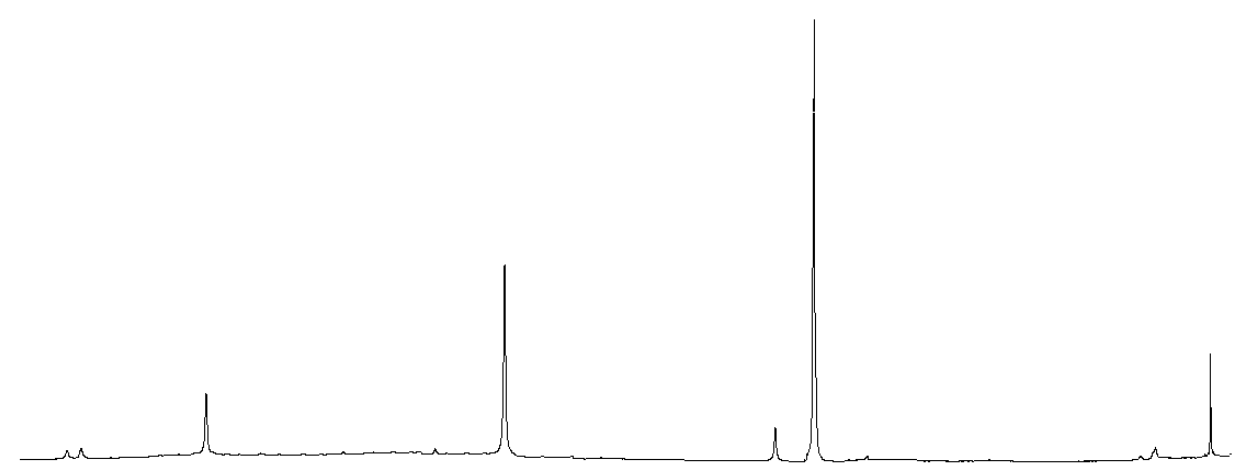

ppm (f1)

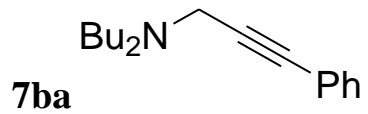

Eluents n-hexane/AcOEt (95:5). Anal. Calc. for $\mathrm{C}_{17} \mathrm{H}_{25} \mathrm{~N}$ (243.39) C, 83.99; H, 10.35; N, 5.75; Found: C, 83.07; H, 9.85; N, 5.37. MS(ESI +): $244(100 \%)[\mathrm{M}]^{+} .{ }^{1} \mathrm{H}$ NMR $\left(400 \mathrm{MHz}, \mathrm{CDCl}_{3}\right): \delta=0.940(\mathrm{t}, 6 \mathrm{H}$, $\left.\mathrm{CH}_{3},{ }^{3} \mathrm{~J}_{\mathrm{HH}}=7.2\right), 1.29-1.41\left(\mathrm{~m}, 4 \mathrm{H}, \mathrm{CH}_{2}\right), 1.44-1.54\left(\mathrm{~m}, 4 \mathrm{H}, \mathrm{CH}_{2}\right), 2.53-2.60\left(\mathrm{~m}, 4 \mathrm{H}, \mathrm{CH}_{2}\right), 3.63(\mathrm{~s}, 2 \mathrm{H}$, $\left.\mathrm{CH}_{2}-\mathrm{C} \equiv \mathrm{C}\right), 7.29-7.32\left(\mathrm{~m}, 3 \mathrm{H}, \mathrm{H}_{\mathrm{p}}+\mathrm{H}_{\mathrm{m}}, \mathrm{Ph}\right), 7.42-7.45\left(\mathrm{~m}, 2 \mathrm{H}, \mathrm{H}_{\mathrm{o}}, \mathrm{Ph}\right) .{ }^{13} \mathrm{C}\left\{{ }^{1} \mathrm{H}\right\} \mathrm{NMR}(400 \mathrm{MHz}$, $\left.\mathrm{CDCl}_{3}\right): \delta=14.12\left(\mathrm{~s}, \mathrm{CH}_{3},{ }^{n} \mathrm{Bu}\right), 26.75\left(\mathrm{~s}, \mathrm{CH}_{2},{ }^{n} \mathrm{Bu}\right), 29.74\left(\mathrm{~s}, \mathrm{CH}_{2},{ }^{n} \mathrm{Bu}\right), 42.67\left(\mathrm{~s}, \mathrm{NCH}_{2}\right), 53.65\left(\mathrm{~s}, \mathrm{CH}_{2}\right.$,

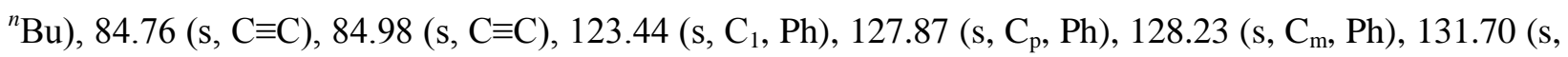
$\left.\mathrm{C}_{\mathrm{o}}, \mathrm{Ph}\right)$. 


\section{NMR ${ }^{1} \mathrm{H} 7 \mathrm{ba}$}

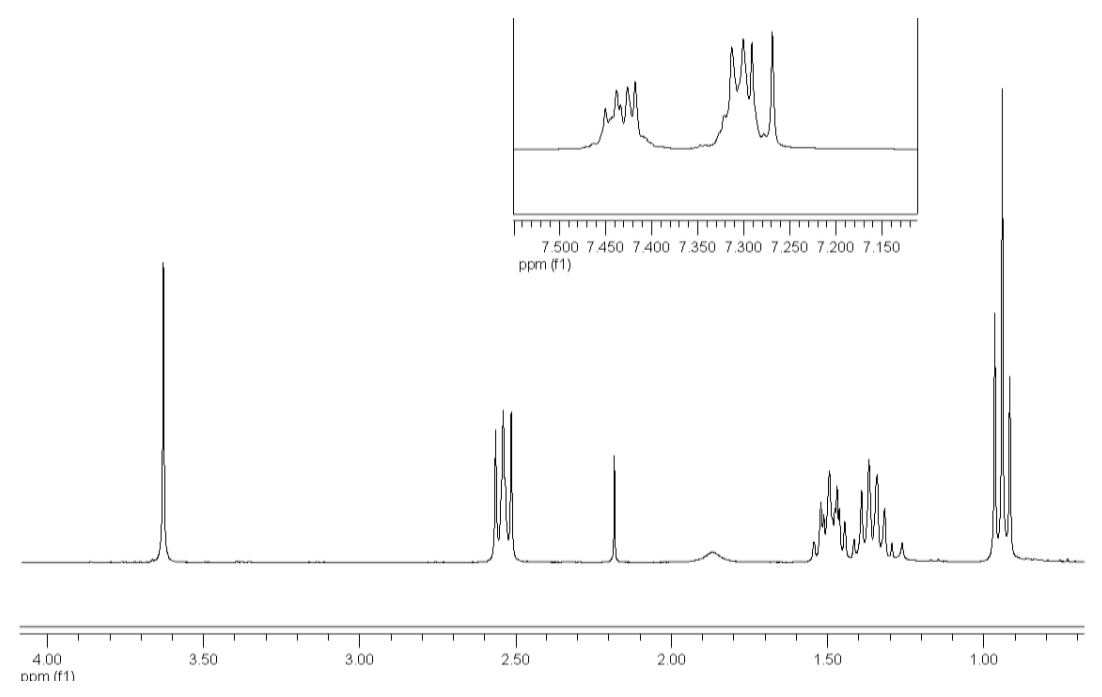

$\mathrm{NMR}{ }^{13} \mathrm{C}\left\{{ }^{1} \mathrm{H}\right\} \mathbf{7 b a}$

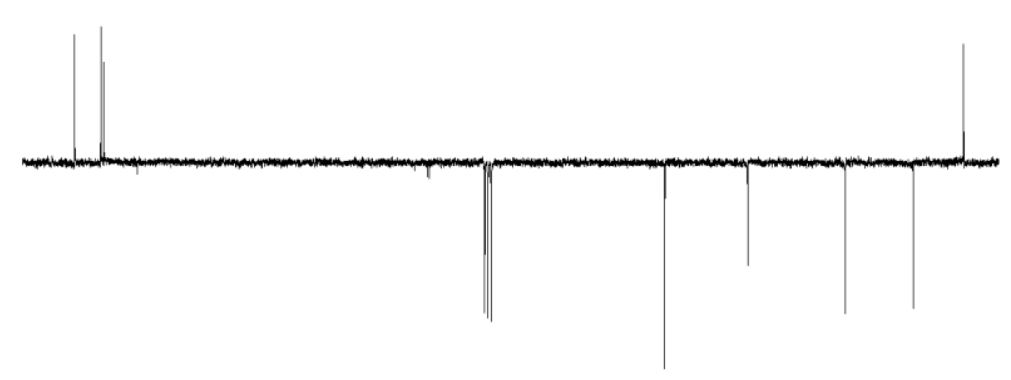

$7 \mathbf{b b}$

$\mathrm{C}_{15} \mathrm{H}_{29} \mathrm{~N}(223.39)$; MS(ESI +): $224(80 \%)[\mathrm{M}]^{+}{ }^{1} \mathrm{H}$ NMR $\left(400 \mathrm{MHz}, \mathrm{CDCl}_{3}\right): \delta=0.94\left(\mathrm{t}, 6 \mathrm{H}, \mathrm{CH}_{3}\right.$, $\left.{ }^{n} \mathrm{Bu},{ }^{3} \mathrm{~J}_{\mathrm{HH}}=7.2\right), 1.23\left(\mathrm{~s}, 9 \mathrm{H},\left(\mathrm{CH}_{3}\right)_{3}\right)$, 1.29-1.47 (m, 8H, $\left.4 \mathrm{CH}_{2},{ }^{n} \mathrm{Bu}\right), 2.43-2.47\left(\mathrm{~m}, 4 \mathrm{H}, 2 \mathrm{CH}_{2},{ }^{n} \mathrm{Bu}\right)$, 3.36 (s, 2H, $\left.\mathrm{CH}_{2}-\mathrm{C} \equiv \mathrm{C}\right) .{ }^{13} \mathrm{C}\left\{{ }^{1} \mathrm{H}\right\}$ NMR (400 $\left.\mathrm{MHz} \mathrm{CDCl}_{3}\right): 14.04\left(\mathrm{~s}, \mathrm{CH}_{3},{ }^{n} \mathrm{Bu}\right), 19.92\left(\mathrm{~s}, \mathrm{CH}_{2},{ }^{n} \mathrm{Bu}\right)$, $29.58\left(\mathrm{~s}, \mathrm{CH}_{2},{ }^{n} \mathrm{Bu}\right), 31.48\left(\mathrm{~s},\left(\mathrm{CH}_{3}\right)_{3}\right), 42.17\left(\mathrm{~s}, \mathrm{NCH}_{2}\right), 53.43\left(\mathrm{~s}, \mathrm{CH}_{2},{ }^{n} \mathrm{Bu}\right), 68.15(\mathrm{~s}, \mathrm{C} \equiv \mathrm{C}), 72.88(\mathrm{~s}$, $\mathrm{C} \equiv \mathrm{C})$. 


\section{NMR ${ }^{1} \mathbf{H}$ 7bb}

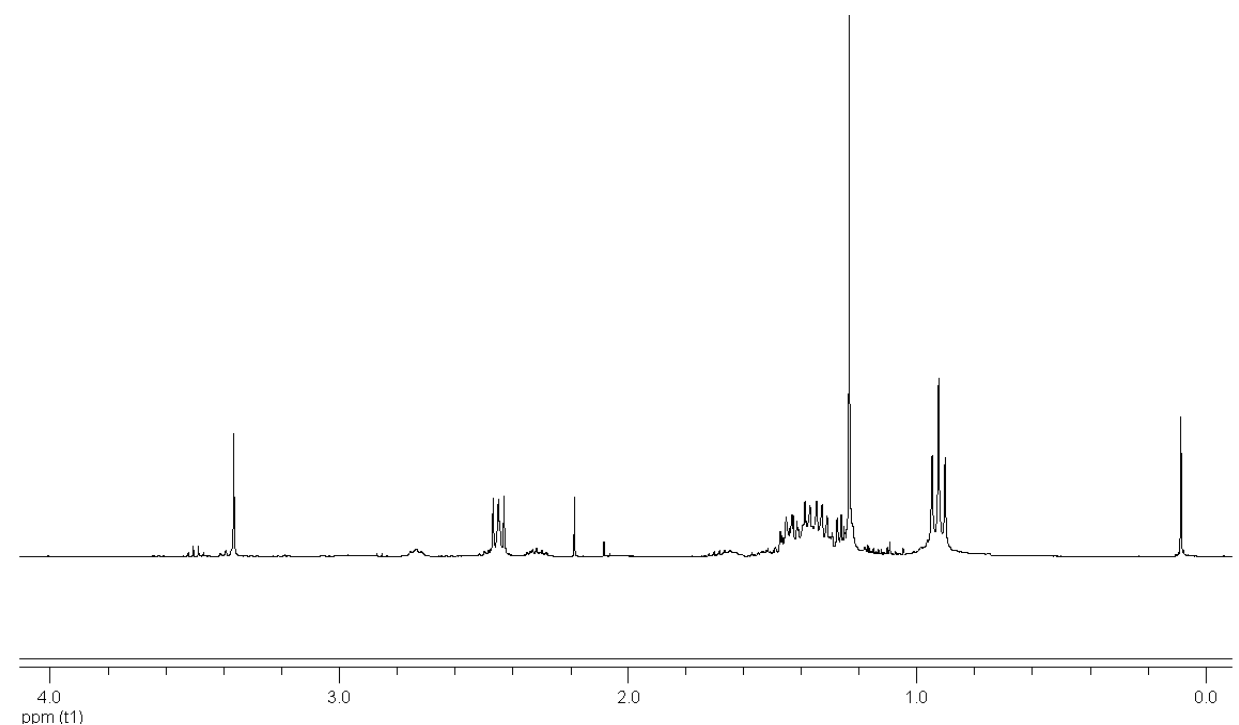

$\mathrm{NMR}{ }^{13} \mathrm{C}\left\{{ }^{1} \mathrm{H}\right\} \mathbf{7 b b}$

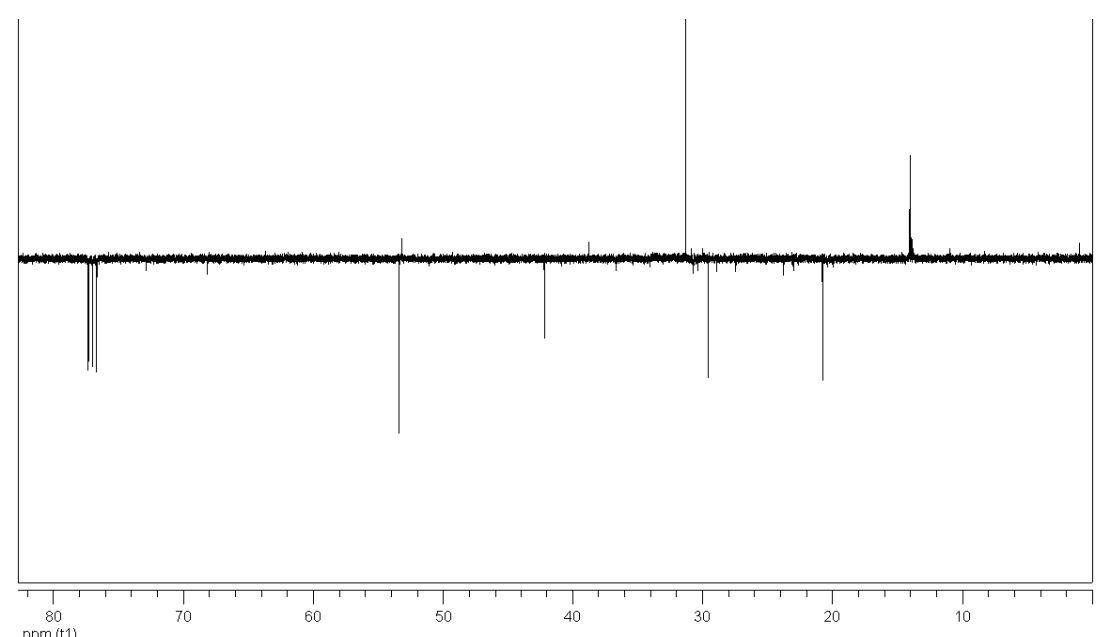

${ }_{7 \mathbf{b c}} \mathrm{Bu}_{2} \mathrm{~N}\left(\mathrm{CH}_{2}\right)_{7}-\mathrm{CH}_{3}$

Eluents n-hexane/AcOEt (80:20). $\mathrm{C}_{19} \mathrm{H}_{37} \mathrm{~N}$ (279.50); MS(ESI +): 28 (45 \%) [M] ${ }^{+} .{ }^{1} \mathrm{H}$ NMR (400 MHz, $\left.\mathrm{CDCl}_{3}\right): \delta=0.88-0.93\left(\mathrm{~m}, 6 \mathrm{H}, \mathrm{CH}_{3},{ }^{n} \mathrm{Bu}+\mathrm{CH}_{3}, \mathrm{C}_{8} \mathrm{H}_{17}\right)$, 1.24-1.58 (m, 20H, 8H, $\mathrm{CH}_{2},{ }^{n} \mathrm{Bu}+12 \mathrm{H}, \mathrm{CH}_{2}$, $\left.\mathrm{C}_{8} \mathrm{H}_{17}\right), 2.38\left(\mathrm{t}, 2 \mathrm{H}, \mathrm{CH}_{2}, \mathrm{C}_{8} \mathrm{H}_{17},{ }^{2} \mathrm{~J}_{\mathrm{HH}}=7.0\right), 2.42-2.47\left(\mathrm{~m}, 4 \mathrm{H}, 2 \mathrm{CH}_{2},{ }^{n} \mathrm{Bu}\right), 3.38\left(\mathrm{~s}, 2 \mathrm{H}, \mathrm{CH}_{2}-\mathrm{C} \equiv \mathrm{C}\right)$. ${ }^{13} \mathrm{C}\left\{{ }^{1} \mathrm{H}\right\}$ NMR (400 MHz, $\mathrm{CDCl}_{3}$ ): 14.09 (overlapped, $\left.\mathrm{CH}_{3},{ }^{n} \mathrm{Bu}+\mathrm{CH}_{3}, \mathrm{C}_{8} \mathrm{H}_{17}\right), 18.70\left(\mathrm{~s}, \mathrm{CH}_{2}, \mathrm{C}_{8} \mathrm{H}_{17}\right)$, $20.64\left(\mathrm{~s}, \mathrm{CH}_{2},{ }^{n} \mathrm{Bu}\right), 23.88\left(\mathrm{~s}, \mathrm{CH}_{2}, \mathrm{C}_{8} \mathrm{H}_{17}\right), 28.92\left(\mathrm{~s}, \mathrm{CH}_{2}, \mathrm{C}_{8} \mathrm{H}_{17}\right), 29.00\left(\mathrm{~s}, \mathrm{CH}_{2}, \mathrm{C}_{8} \mathrm{H}_{17}\right), 29.17\left(\mathrm{~s}, \mathrm{CH}_{2}\right.$, 
$\left.\mathrm{C}_{8} \mathrm{H}_{17}\right), 29.69\left(\mathrm{~s}, \mathrm{CH}_{2}, \mathrm{C}_{8} \mathrm{H}_{17}\right), 29.78\left(\mathrm{~s}, \mathrm{CH}_{2},{ }^{n} \mathrm{Bu}\right), 32.05\left(\mathrm{~s}, \mathrm{CH}_{2}, \mathrm{C}_{8} \mathrm{H}_{17}\right), 43.83\left(\mathrm{~s}, \mathrm{NCH}_{2}\right), 53.49$ (s, $\left.\mathrm{CH}_{2},{ }^{n} \mathrm{Bu}\right) .(\mathrm{C} \equiv \mathrm{C}$ signal was not observed $)$.<smiles>Cl[Ge]</smiles>

Eluents n-hexane/ $\mathrm{Et}_{2} \mathrm{O}$ (90:20). $\mathrm{C}_{21} \mathrm{H}_{33} \mathrm{~N}$ (299.49). ${ }^{1} \mathrm{H}$ NMR (400 MHz, $\left.\mathrm{CDCl}_{3}\right): \delta=0.80\left(\mathrm{t}, 6 \mathrm{H}, \mathrm{CH}_{3}, \mathrm{n}\right.$ hexyl, $\left.{ }^{3} \mathrm{~J}_{\mathrm{HH}}=7.1\right), 1.18-1.26\left(\mathrm{~m}, 16 \mathrm{H}, \mathrm{CH}_{2}\right.$, n-hexyl), 2.42-2.45 (m, 4H, $2 \mathrm{NCH}_{2}, \mathrm{n}$-hexyl), 3.52 (s, $2 \mathrm{H}$, $\left.\mathrm{NCH}_{2}-\mathrm{C} \equiv \mathrm{C}\right), 7.18-7.23\left(\mathrm{~m}, 3 \mathrm{H}, \mathrm{H}_{\mathrm{p}}+\mathrm{H}_{\mathrm{m}}, \mathrm{Ph}\right), 7.38-7.41\left(\mathrm{~m}, 2 \mathrm{H}, \mathrm{H}_{\mathrm{o}}, \mathrm{Ph}\right) .{ }^{13} \mathrm{C}\left\{{ }^{1} \mathrm{H}\right\} \mathrm{NMR}(100 \mathrm{MHz}$, $\left.\mathrm{CDCl}_{3}\right): \delta=13.10$ (s, $\mathrm{CH}_{3}, \mathrm{n}$-hexyl), 21.67, 26.25, 26.56, 30.84 (s, $\mathrm{CH}_{2}$, n-hexyl), $41.67\left(\mathrm{~s}, \mathrm{NCH}_{2}\right), 50.84$

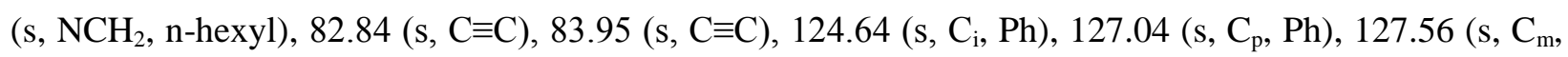
$\mathrm{Ph}), 128.54$ (s, $\left.\mathrm{C}_{\mathrm{o}}, \mathrm{Ph}\right)$.

\section{$7 \mathbf{c b}$}

$\mathrm{C}_{19} \mathrm{H}_{37} \mathrm{~N}$ (279.50). ${ }^{1} \mathrm{H}$ NMR (400 MHz, $\mathrm{CDCl}_{3}$ ): $\delta=0.87\left(\mathrm{t}, 6 \mathrm{H}, \mathrm{CH}_{3}\right.$, n-hexyl, ${ }^{3} \mathrm{~J}_{\mathrm{HH}}=7.2$ ), 1.18 (s, 9H, $\left.\left(\mathrm{CH}_{3}\right)_{3}\right), 1.19-1.30$ (m, $16 \mathrm{H}, \mathrm{CH}_{2}$, n-hexyl), 2.33-2.36 (m, 4H, $2 \mathrm{NCH}_{2}$, n-hexyl), 3.28 (s, $\left.2 \mathrm{H}, \mathrm{NCH}_{2}-\mathrm{C} \equiv \mathrm{C}\right) .{ }^{13} \mathrm{C}\left\{{ }^{1} \mathrm{H}\right\} \mathrm{NMR}\left(100 \mathrm{MHz}, \mathrm{CDCl}_{3}\right): \delta=13.09\left(\mathrm{~s}, \mathrm{CH}_{3}, \mathrm{n}\right.$-hexyl), 21.71, 26.31, 26.66 (s, $\mathrm{CH}_{2}$, n-hexyl), 30.48 (s, $\left.\left(\mathrm{CH}_{3}\right)_{3}\right), 30.82$ (s, $\mathrm{CH}_{2}, \mathrm{n}$-hexyl), 41.13 (s, $\mathrm{NCH}_{2}$ ), 51.38 (s, $\mathrm{NCH}_{2}$, n-hexyl), 87.56 (s, C $\left.\equiv \mathrm{C}\right), 91.96$ (s, C $\equiv \mathrm{C}$ ). (Quaternary $\mathrm{C}$ atom of ${ }^{\mathrm{t}} \mathrm{Bu}$ not observed).

\section{NMR ${ }^{1} \mathbf{H} 7 \mathbf{c b}$}
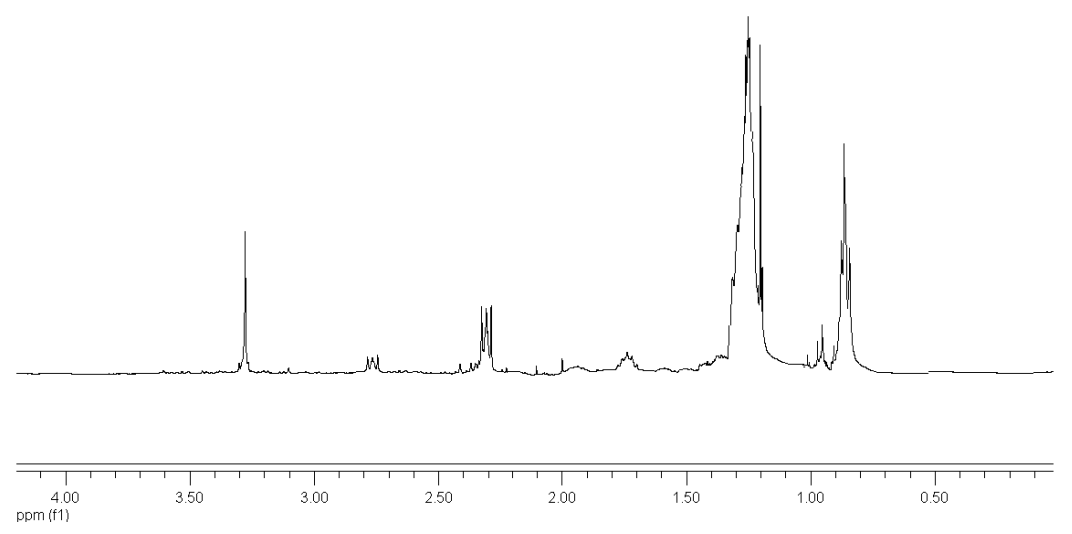

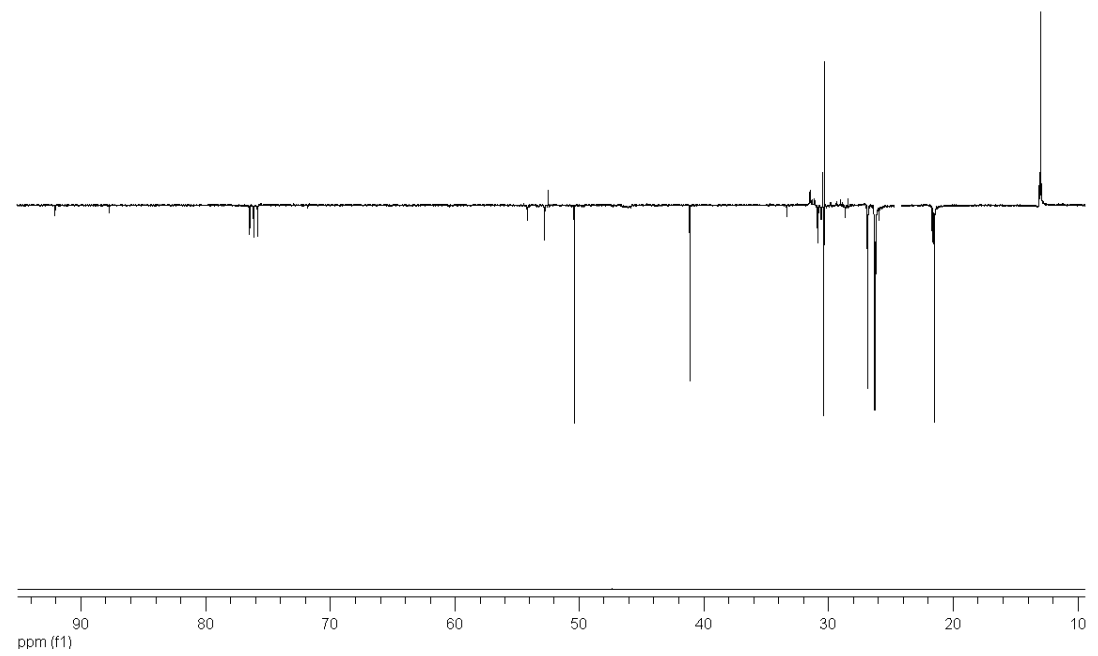

${ }_{7 \mathrm{cc}}$

Eluents n-hexane/AcOEt (95:5). $\mathrm{C}_{23} \mathrm{H}_{45} \mathrm{~N}$ (335.61). ${ }^{1} \mathrm{H} \mathrm{NMR}\left(400 \mathrm{MHz}, \mathrm{CDCl}_{3}\right): \delta=0.84-0.89(\mathrm{~m}, 9 \mathrm{H}$, $\mathrm{CH}_{3}$, n-hexyl $\left.+\mathrm{CH}_{3}, \mathrm{C}_{8} \mathrm{H}_{17}\right), 1.27-1.55\left(\mathrm{~m}, 30 \mathrm{H}, 6 \mathrm{H}, \mathrm{CH}_{2}, \mathrm{C}_{8} \mathrm{H}_{17}, 12 \mathrm{H}, \mathrm{CH}_{2}\right.$, n-hexyl), 2.40 (t, 2H, $\mathrm{CH}_{2}$, $\mathrm{C}_{8} \mathrm{H}_{17},{ }^{2} \mathrm{~J}_{\mathrm{HH}}=7.5$ ), 2.48-2.49 (m, 4H, $2 \mathrm{NCH}_{2}, \mathrm{n}$-hexyl), 3.39 (s, $\left.2 \mathrm{H}, \mathrm{NCH}_{2}-\mathrm{C} \equiv \mathrm{C}\right) .{ }^{13} \mathrm{C}\left\{{ }^{1} \mathrm{H}\right\} \mathrm{NMR}(400$ $\mathrm{MHz}, \mathrm{CDCl}_{3}$ ): $\delta=13.91$ (overlapped, $\mathrm{CH}_{3}$, n-hexyl $+\mathrm{CH}_{3}, \mathrm{C}_{8} \mathrm{H}_{17}$ ), 18.10, 22.76, 22.95, 27.10, 27.69, 28.47, 28.68, 29.01, 29.57, 30.84, 31.79 (s, $\left.\mathrm{CH}_{2}\right), 43.27$ (s, $\left.\mathrm{NCH}_{2}\right), 51.45$ (s, $\mathrm{NCH}_{2}$, n-hexyl). (C $\equiv \mathrm{C}$ signal was not observed).

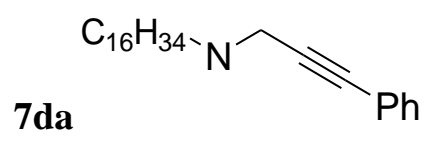

Eluents n-hexane/ $\mathrm{Et}_{2} \mathrm{O}$ (90:20). $\mathrm{C}_{25} \mathrm{H}_{41} \mathrm{~N}$ (355.60). ${ }^{1} \mathrm{H}$ NMR (400 MHz, $\mathrm{CDCl}_{3}$ ): $\delta=0.81$ (t, 6H, $\mathrm{CH}_{3}, \mathrm{n}$ octyl, ${ }^{3} \mathrm{~J}_{\mathrm{HH}}=7.3$ ), 1.18-1.22 (m, $24 \mathrm{H}, \mathrm{CH}_{2}$, n-octyl), 2.42-2.46 (m, 4H, $2 \mathrm{NCH}_{2}$, n-octyl), 3.53 (s, $2 \mathrm{H}$, $\left.\mathrm{NCH}_{2}-\mathrm{C} \equiv \mathrm{C}\right), 7.19-7.22\left(\mathrm{~m}, 3 \mathrm{H}, \mathrm{H}_{\mathrm{p}}+\mathrm{H}_{\mathrm{m}}, \mathrm{Ph}\right), 7.41-7.43\left(\mathrm{~m}, 2 \mathrm{H}, \mathrm{H}_{\mathrm{o}}, \mathrm{Ph}\right) .{ }^{13} \mathrm{C}\left\{{ }^{1} \mathrm{H}\right\} \mathrm{NMR}(100 \mathrm{MHz}$, $\mathrm{CDCl}_{3}$ ): $\delta=14.09$ (s, $\mathrm{CH}_{3}$, n-octyl), 22.66, 27.55, 29.29, 29.55, 31.86, 32.80 (s, $\mathrm{CH}_{2}, \mathrm{n}$-octyl), 42.65 (s,

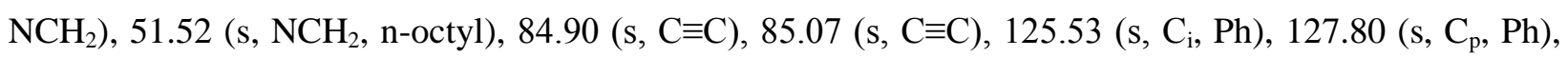
$128.27\left(\mathrm{~s}, \mathrm{C}_{\mathrm{m}}, \mathrm{Ph}\right), 128.73\left(\mathrm{~s}, \mathrm{C}_{\mathrm{o}}, \mathrm{Ph}\right)$. 


\section{NMR ${ }^{1} \mathbf{H} 7 \mathbf{d a}$}
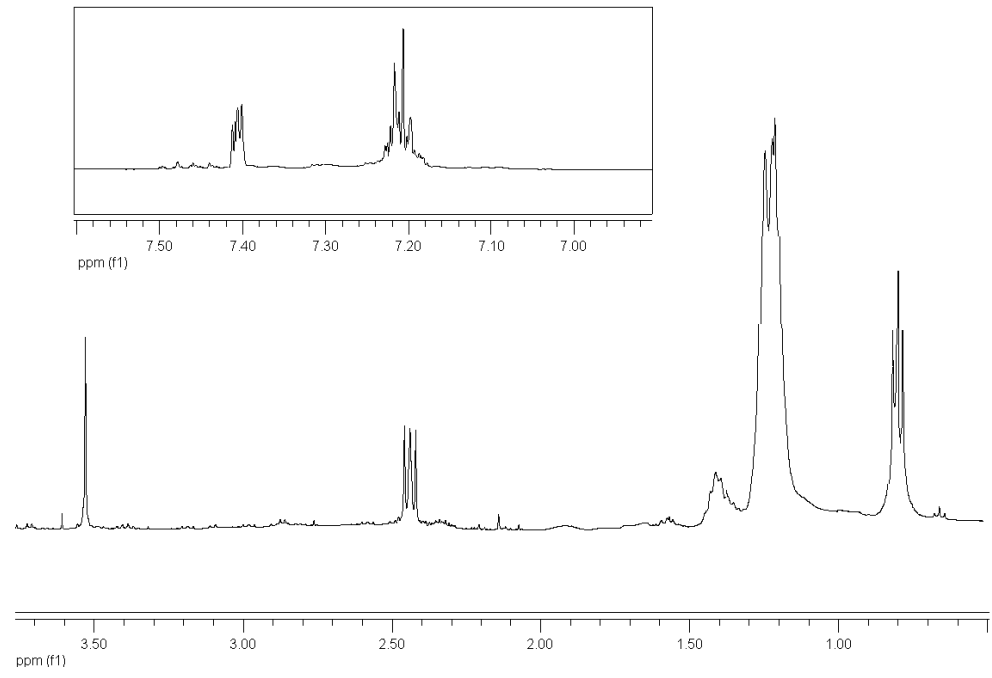

$\mathrm{NMR}{ }^{13} \mathrm{C}\left\{{ }^{1} \mathrm{H}\right\} \mathbf{7 d a}$

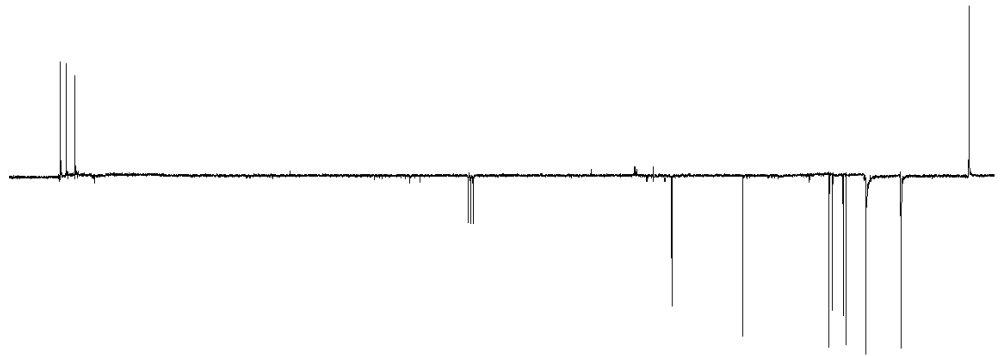

ppm (11)

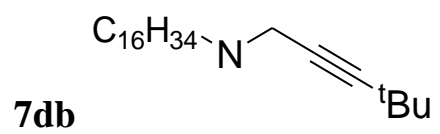

$\mathrm{C}_{23} \mathrm{H}_{45} \mathrm{~N}$ (335.61). ${ }^{1} \mathrm{H}$ NMR (400 MHz, $\left.\mathrm{CDCl}_{3}\right): \delta=0.80\left(\mathrm{t}, 6 \mathrm{H}, \mathrm{CH}_{3}, \mathrm{n}\right.$-octyl, $\left.{ }^{3} \mathrm{~J}_{\mathrm{HH}}=7.1\right), 1.13-1.35(\mathrm{~m}$, $33 \mathrm{H}, 9 \mathrm{H},\left(\mathrm{CH}_{3}\right)_{3}, 24 \mathrm{H}, \mathrm{CH}_{2}$, n-octyl), 2.33-2.36 (m, 4H, $2 \mathrm{NCH}_{2}$, n-octyl), 3.27 (s, 2H, $\mathrm{NCH}_{2}-\mathrm{C} \equiv \mathrm{C}$ ). 
${ }^{13} \mathrm{C}\left\{{ }^{1} \mathrm{H}\right\}$ NMR (100 MHz, $\left.\mathrm{CDCl}_{3}\right): \delta=13.14$ (s, $\mathrm{CH}_{3}$, n-octyl), 21.72, 26.44, 26.65, 28.35, (s, $\mathrm{CH}_{2}, \mathrm{n}$ octyl), 30.51(s, $\left(\mathrm{CH}_{3}\right)_{3}$ ), 30.92 (br, 2 $\mathrm{CH}_{2}$, n-octyl), 41.14 (s, $\mathrm{NCH}_{2}$ ), 50.37 (s, $\mathrm{NCH}_{2}$, n-octyl), 88.69 (s, $\mathrm{C} \equiv \mathrm{C}), 91.99$ ( $\mathrm{s}, \mathrm{C} \equiv \mathrm{C}$ ) (quaternary $\mathrm{C}$ atom of ${ }^{\mathrm{t}} \mathrm{Bu}$ not observed).

$\left.{ }_{7 d c} \mathrm{C}_{16} \mathrm{H}_{34-}-\mathrm{CH}_{2}\right)_{7} \mathrm{CH}_{3}$

Eluents n-hexane/AcOEt (95:5). $\mathrm{C}_{27} \mathrm{H}_{53} \mathrm{~N}$ (391.72). ${ }^{1} \mathrm{H} \mathrm{NMR}\left(400 \mathrm{MHz}, \mathrm{CDCl}_{3}\right): \delta=0.78-0.81(\mathrm{~m}, 9 \mathrm{H}$, $\mathrm{CH}_{3}$, n-octyl $\left.+\mathrm{CH}_{3}, \mathrm{C}_{8} \mathrm{H}_{17}\right), 1.20-1.48\left(\mathrm{~m}, 30 \mathrm{H}, 6 \mathrm{H}, \mathrm{CH}_{2}, \mathrm{C}_{8} \mathrm{H}_{17}+24 \mathrm{H}, \mathrm{CH}_{2}\right.$, n-octyl), 2.34 (t, $2 \mathrm{H}, \mathrm{CH}_{2}$, $\mathrm{C}_{8} \mathrm{H}_{17},{ }^{2} \mathrm{~J}_{\mathrm{HH}}=7.3$ ), 2.42-2.45 (m, 4H, $2 \mathrm{NCH}_{2}$, n-octyl), 3.27 (s, $\left.2 \mathrm{H}, \mathrm{NCH}_{2}-\mathrm{C} \equiv \mathrm{C}\right) .{ }^{13} \mathrm{C}\left\{{ }^{1} \mathrm{H}\right\} \mathrm{NMR}(100$ $\mathrm{MHz}, \mathrm{CDCl}_{3}$ ): $\delta=13.08,13.11$ (s, $\mathrm{CH}_{3}, \mathrm{C}_{8} \mathrm{H}_{17}$, n-octyl), 17.69, 17.72, 21.64, 21.66, 22.90, 25.81, 26.11, 27.90, 27.94, 28.39, 28.44, 29.57, 30.79 (s, $\left.\mathrm{CH}_{2}\right), 42.82$ (s, $\left.\mathrm{NCH}_{2}\right), 50.55$ (s, $\mathrm{NCH}_{2}$, n-octyl). ( $\mathrm{C} \equiv \mathrm{C}$ signal was not observed).

7ea<smiles>C(#Cc1ccccc1)CN1CCCCC1</smiles>

Eluents n-hexane/AcOEt (90:10). $\mathrm{C}_{14} \mathrm{H}_{17} \mathrm{~N}$ (199.29). ${ }^{1} \mathrm{H} \mathrm{NMR}\left(400 \mathrm{MHz}, \mathrm{CDCl}_{3}\right): \delta=1.49-1.59(\mathrm{~m}$, 6H, $\mathrm{CH}_{2}$, piperidine), 2.30-2.37 (m, 4H, $\mathrm{NCH}_{2}$, piperidine), $4.06\left(\mathrm{~s}, 2 \mathrm{H}, \mathrm{NCH}_{2}-\mathrm{C} \equiv \mathrm{C}\right)$, 7.22-7.28 (m, 3H, $\left.\mathrm{H}_{\mathrm{p}}+\mathrm{H}_{\mathrm{m}}, \mathrm{Ph}\right)$, 7.44-7.47 (m, 2H, $\left.\mathrm{H}_{\mathrm{o}}, \mathrm{Ph}\right) .{ }^{13} \mathrm{C}\left\{{ }^{1} \mathrm{H}\right\} \mathrm{NMR}\left(400 \mathrm{MHz}, \mathrm{CDCl}_{3}\right): \delta=22.93\left(\mathrm{~s}, \mathrm{CH}_{2}\right.$, piperidine), 25.85 (s, $\mathrm{CH}_{2}$, piperidine), 45.97 (s, $\mathrm{NCH}_{2}$ ), 50.84 (s, $\mathrm{NCH}_{2}$, piperidine), 80.94 (s, $\mathrm{C} \equiv \mathrm{C}$ ), 82.63 (s, C $\equiv C), 121.07\left(s, C_{1}, P h\right), 127.55\left(s, C_{p}, P h\right), 128.00$ (s, $\left.C_{m}, P h\right), 131.30\left(s, C_{0}, P h\right)$.<smiles>CC(C)(C)C#CCN1CCCCC1</smiles>

$\mathrm{C}_{12} \mathrm{H}_{21} \mathrm{~N}$ (179.30). ${ }^{1} \mathrm{H}$ NMR (400 $\left.\mathrm{MHz} \mathrm{CDCl}_{3}\right): \delta=1.16\left(\mathrm{~s}, 9 \mathrm{H},\left(\mathrm{CH}_{3}\right)_{3}\right), 1.53-1.60\left(\mathrm{~m}, 6 \mathrm{H}, \mathrm{CH}_{2}\right.$, piperidine), 2.39-2.42 (m, 4H, $\mathrm{NCH}_{2}$, piperidine), 3.16 (s, $\left.2 \mathrm{H}, \mathrm{NCH}_{2}-\mathrm{C} \equiv \mathrm{C}\right) .{ }^{13} \mathrm{C}\left\{{ }^{1} \mathrm{H}\right\} \mathrm{NMR}(100 \mathrm{MHz}$, $\left.\mathrm{CDCl}_{3}\right): \delta=21.50$ (s, $\mathrm{CH}_{2}$, piperidine), $24.78\left(\mathrm{~s}, \mathrm{CH}_{2}\right.$, piperidine), $30.20\left(\mathrm{~s},\left(\mathrm{CH}_{3}\right)_{3}\right), 43.54\left(\mathrm{~s}, \mathrm{NCH}_{2}\right)$, 52.18 ( $\mathrm{s}, \mathrm{NCH}_{2}$, piperidine), 85.24 (s, C $\equiv \mathrm{C}$ ), 92.96 (s, C $\equiv \mathrm{C}$ ). (Quaternary $\mathrm{C}$ atom of ${ }^{\mathrm{t}} \mathrm{Bu}$ not observed). 
NMR ${ }^{1}$ H 7eb

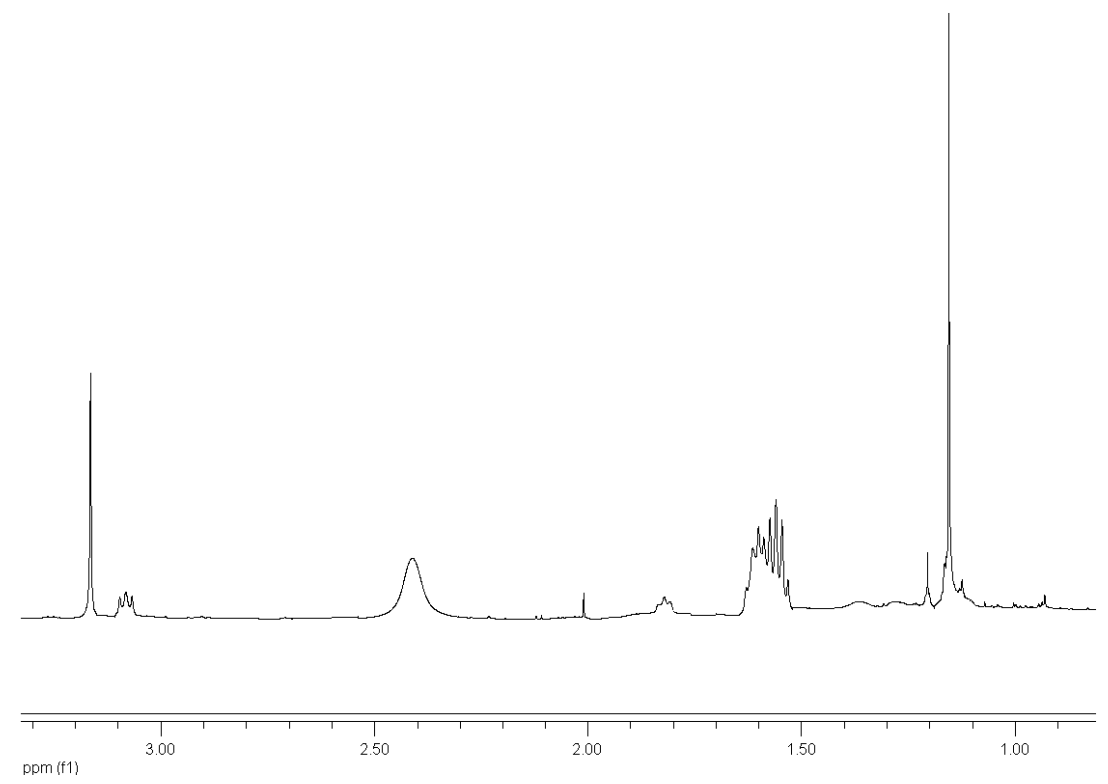

NMR ${ }^{13} \mathrm{C}\left\{{ }^{1} \mathrm{H}\right\}$ 7eb
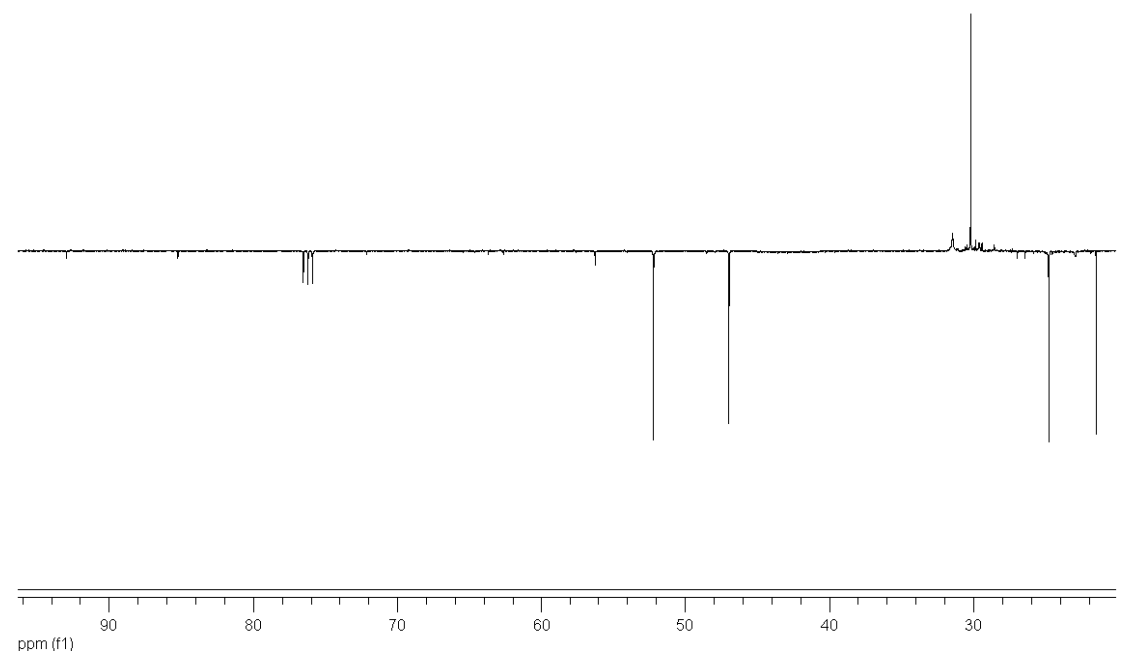
$\overbrace{7 \mathrm{ec}} \mathrm{CH}_{2})_{7} \mathrm{CH}_{3}$

Eluents n-hexane/AcOEt (95:5). $\mathrm{C}_{16} \mathrm{H}_{29} \mathrm{~N}$ (235.41). ${ }^{1} \mathrm{H} \mathrm{NMR}\left(400 \mathrm{MHz}, \mathrm{CDCl}_{3}\right): \delta=0.90\left(\mathrm{t}, 6 \mathrm{H}, \mathrm{CH}_{3}, \mathrm{n}-\right.$ hexyl, $\left.{ }^{3} \mathrm{~J}_{\mathrm{HH}}=7.1\right), 1.24-1.50\left(\mathrm{~m}, 24 \mathrm{H}, 6 \mathrm{H}, \mathrm{CH}_{2}, \mathrm{C}_{8} \mathrm{H}_{17}+6 \mathrm{H}, \mathrm{CH}_{2}\right.$, piperidine), 2.05-2.10 (m, $2 \mathrm{H}, \mathrm{CH}_{2}$, $\mathrm{C}_{8} \mathrm{H}_{17}$ ), 2.25-2.27 (m, 4H, $\mathrm{NCH}_{2}$, piperidine), 3.25 (s, $\left.2 \mathrm{H}, \mathrm{CH}_{2}-\mathrm{C} \equiv \mathrm{C}\right) .{ }^{13} \mathrm{C}\left\{{ }^{1} \mathrm{H}\right\} \mathrm{NMR}\left(400 \mathrm{MHz}, \mathrm{CDCl}_{3}\right.$ ): $\delta=13.90\left(\mathrm{~s}, \mathrm{CH}_{3}, \mathrm{C}_{8} \mathrm{H}_{17},\right), 18.91,21.51,23.04,25.61,28.42,28.71,29.15,29.68,31.51\left(\mathrm{~s}, \mathrm{CH}_{2}\right), 43.12(\mathrm{~s}$, $\left.\mathrm{NCH}_{2}\right), 52.31\left(\mathrm{~s}, \mathrm{NCH}_{2},{ }^{n} \mathrm{Bu}\right) .(\mathrm{C} \equiv \mathrm{C}$ signal was not observed).<smiles>CN(C)CC#C[SiH3]</smiles>

$\mathrm{C}_{8} \mathrm{H}_{17} \mathrm{NSi}(155.31)$; MS(ESI +): $156(80 \%)[\mathrm{M}]^{+}{ }^{+} \mathrm{H}$ NMR $\left(400 \mathrm{MHz}, \mathrm{CDCl}_{3}\right): \delta=0.10\left(\mathrm{~s}, 9 \mathrm{H}, \mathrm{SiMe}_{3}\right)$, 2.29 (s, 6H, $\left.\mathrm{NCH}_{3}\right), 3.27\left(\mathrm{~s}, 2 \mathrm{H}, \mathrm{CH}_{2}-\mathrm{C} \equiv \mathrm{C}\right) .{ }^{13} \mathrm{C}\left\{{ }^{1} \mathrm{H}\right\} \mathrm{NMR}\left(400 \mathrm{MHz}, \mathrm{CDCl}_{3}\right): 0.15$ (s, $\left.\mathrm{SiMe}_{3}\right), 43.44(\mathrm{~s}$, $\left.\mathrm{NMe}_{2}\right), 48.24$ (s, $\left.\mathrm{NCH}_{2}\right)$. See spectrum 8ad below.

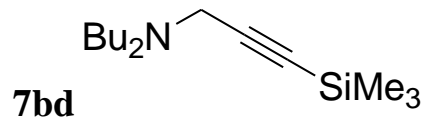

Eluents n-hexane/Et $t_{2} \mathrm{O}$ (90:10). Anal. Calc. for $\mathrm{C}_{14} \mathrm{H}_{29} \mathrm{NSi}(239.47) \mathrm{C}, 70.22 ; \mathrm{H}, 12.21 ; \mathrm{N}, 5.85$; Found: C, 69.88; H, 11.83; N, 5.46. MS(ESI +): 240 (100\%) [M] $]^{+} .{ }^{1} \mathrm{H}$ NMR (400 MHz, $\left.\mathrm{CDCl}_{3}\right)$ : $\delta=0.00\left(\mathrm{~s}, 9 \mathrm{H}, \mathrm{SiMe}_{3}\right), 0.75\left(\mathrm{t}, 6 \mathrm{H}, \mathrm{CH}_{3},{ }^{n} \mathrm{Bu},{ }^{3} \mathrm{~J}_{\mathrm{HH}}=7.2\right), 1.13-1.30\left(\mathrm{~m}, 8 \mathrm{H}, 4 \mathrm{CH}_{2},{ }^{n} \mathrm{Bu}\right), 2.26-$ $2.30\left(\mathrm{~m}, 4 \mathrm{H}, 2 \mathrm{CH}_{2},{ }^{n} \mathrm{Bu}\right), 3.23\left(\mathrm{~s}, 2 \mathrm{H}, \mathrm{CH}_{2}-\mathrm{C} \equiv \mathrm{C}\right) \cdot{ }^{13} \mathrm{C}\left\{{ }^{1} \mathrm{H}\right\} \mathrm{NMR}\left(400 \mathrm{MHz}, \mathrm{CDCl}_{3}\right): \delta=0.02(\mathrm{~s}$, $\mathrm{SiMe}_{3}$ ), 13.95 (s, $\mathrm{CH}_{3},{ }^{n} \mathrm{Bu}$ ), 20.59 (s, $\mathrm{CH}_{2},{ }^{n} \mathrm{Bu}$ ), 29.49 (s, $\mathrm{CH}_{2},{ }^{n} \mathrm{Bu}$ ), 42.85 (s, $\mathrm{NCH}_{2}$ ), 53.37 (s, $\left.\mathrm{CH}_{2},{ }^{n} \mathrm{Bu}\right), 89.30(\mathrm{~s}, \mathrm{C} \equiv \mathrm{C}), 101.30(\mathrm{~s}, \mathrm{C} \equiv \mathrm{C})$.

\section{NMR ${ }^{1}$ H 7bd}




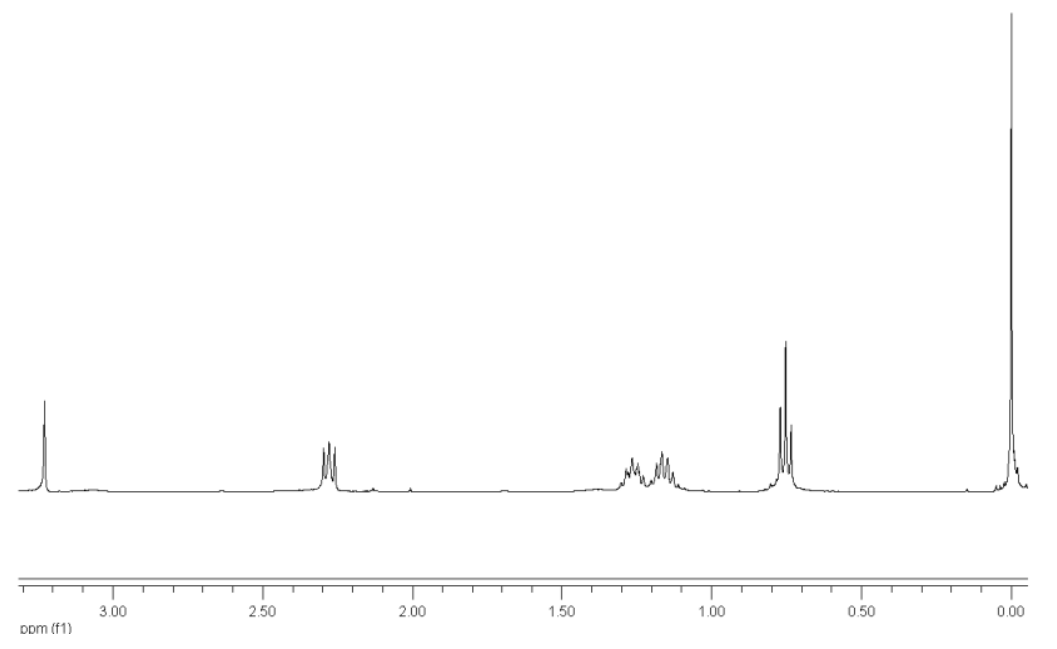

$\mathrm{NMR}{ }^{13} \mathrm{C}\left\{{ }^{1} \mathrm{H}\right\} \mathbf{7 b d}$
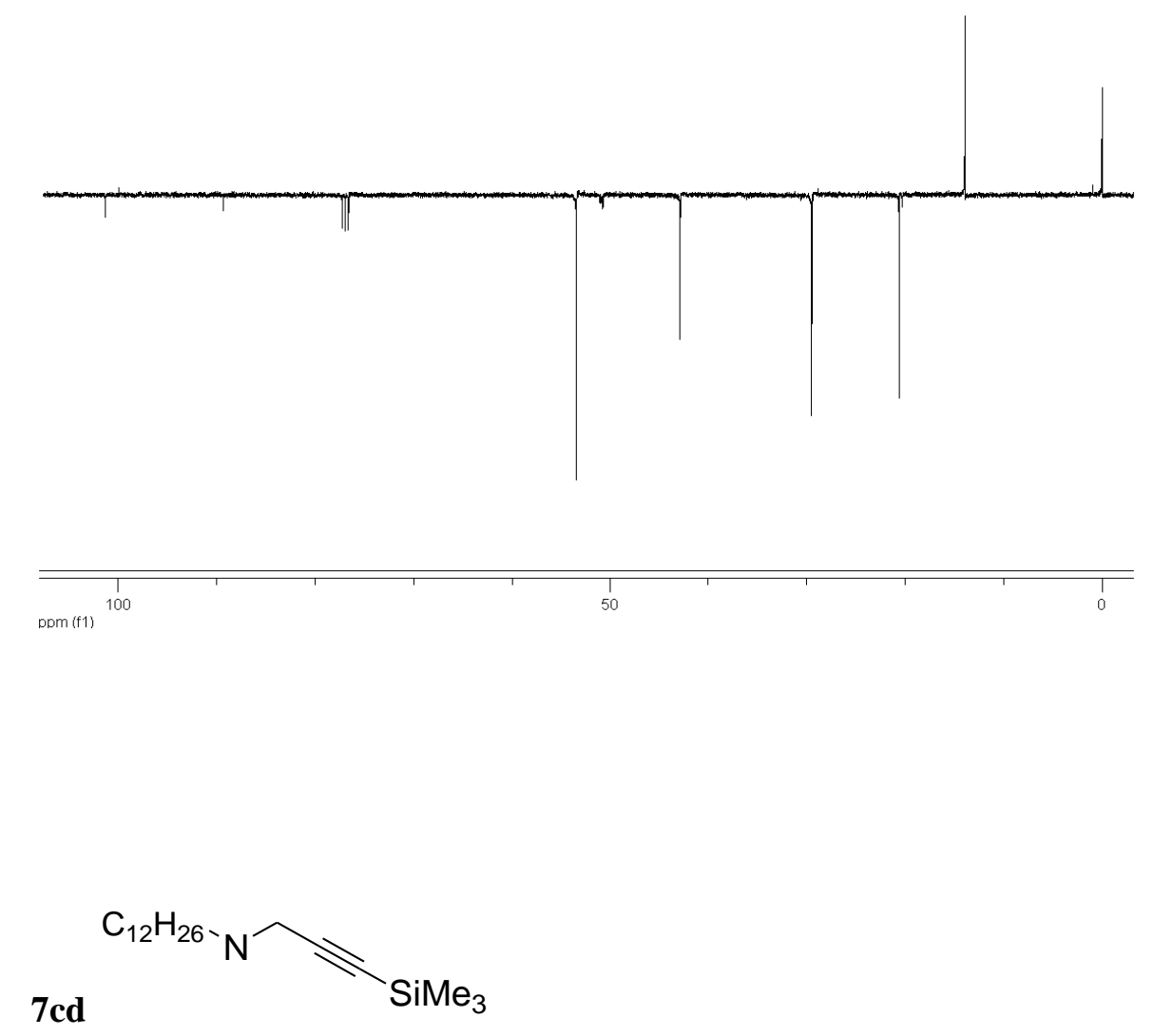

Eluents n-hexane/AcOEt (90:10). $\mathrm{C}_{18} \mathrm{H}_{37} \mathrm{NSi}$ (295.58). ${ }^{1} \mathrm{H} \mathrm{NMR}\left(400 \mathrm{MHz}, \mathrm{CDCl}_{3}\right): \delta=0.08$ (s, 9H, $\mathrm{SiMe}_{3}$ ), 0.87 (t, 6H, $\mathrm{CH}_{3}$, n-hexyl, $\left.{ }^{3} \mathrm{~J}_{\mathrm{HH}}=7.2\right), 1.22-1.28$ (m, $16 \mathrm{H}, \mathrm{CH}_{2}$, n-hexyl), 2.25-2.29 (m, 4H, 2 $\mathrm{NCH}_{2}, \mathrm{n}$-hexyl), 3.34 (s, 2H, $\left.\mathrm{NCH}_{2}-\mathrm{C} \equiv \mathrm{C}\right) .{ }^{13} \mathrm{C}\left\{{ }^{1} \mathrm{H}\right\} \mathrm{NMR}\left(100 \mathrm{MHz}, \mathrm{CDCl}_{3}\right): \delta=0.08\left(\mathrm{~s}, \mathrm{SiMe}_{3}\right), 13.74$ (s, $\mathrm{CH}_{3}$, n-hexyl), 21.40, 27.09, 27.95, 30.51 (s, $\mathrm{CH}_{2}$, n-hexyl), 42.40 (s, $\left.\mathrm{NCH}_{2}\right), 51.86$ (s, $\mathrm{NCH}_{2}$, n-hexyl) $(\mathrm{C} \equiv \mathrm{C}$ signal was not observed). 
Eluents n-hexane/AcOEt (90:10). $\mathrm{C}_{22} \mathrm{H}_{45} \mathrm{NSi}$ (351.68). ${ }^{1} \mathrm{H}$ NMR (400 MHz, $\mathrm{CDCl}_{3}$ ): $\delta=0.12$ (s, 9H, $\mathrm{SiMe}_{3}$ ), 0.83 (t, 6H, $\mathrm{CH}_{3}, \mathrm{n}$-octyl, ${ }^{3} \mathrm{~J}_{\mathrm{HH}}=7.2$ ), 1.23-1.29 (m, $24 \mathrm{H}, \mathrm{CH}_{2}$, n-octyl), 2.37-2.41 (m, 4H, 2 $\mathrm{NCH}_{2}, \mathrm{n}$-octyl), 3.34 (s, 2H, NCH $\left.2-\mathrm{C} \equiv \mathrm{C}\right) .{ }^{13} \mathrm{C}\left\{{ }^{1} \mathrm{H}\right\} \mathrm{NMR}\left(100 \mathrm{MHz}, \mathrm{CDCl}_{3}\right): \delta=0.08$ (s, $\left.\mathrm{SiMe}_{3}\right), 13.50$ (s, $\mathrm{CH}_{3}$, n-octyl), 22.08, 26.75, 27.03, 27.52, 29.40, 31.46 (s, $\mathrm{CH}_{2}$, n-octyl), 42.50 (s, $\mathrm{NCH}_{2}$ ), 51.48 (s, $\mathrm{NCH}_{2}$, n-octyl), $(\mathrm{C} \equiv \mathrm{C}$ not observed $)$.

7ed<smiles>C[SiH2]C#CCN1CCCCC1</smiles>

Eluents n-hexane/AcOEt (90:10). $\mathrm{C}_{11} \mathrm{H}_{21} \mathrm{NSi}(195.38) .{ }^{1} \mathrm{H} \mathrm{NMR}\left(400 \mathrm{MHz}, \mathrm{CDCl}_{3}\right): \delta=0.09$ (s, 9H, $\mathrm{SiMe}_{3}$ ), 1.60-1.67 (m, 6H, $\mathrm{CH}_{2}$, piperidine), 2.38-2.42 (m, 4H, $\mathrm{NCH}_{2}$, piperidine), 3.30 (s, 2H, $\mathrm{NCH}_{2}-$ $\mathrm{C} \equiv \mathrm{C}) .{ }^{13} \mathrm{C}\left\{{ }^{1} \mathrm{H}\right\} \mathrm{NMR}\left(100 \mathrm{MHz}, \mathrm{CDCl}_{3}\right): \delta=1.02\left(\mathrm{~s}, \mathrm{SiMe}_{3}\right), 21.30\left(\mathrm{~s}, \mathrm{CH}_{2}\right.$, piperidine), 25.84 (s, $\mathrm{CH}_{2}$, piperidine), 42.80 (s, $\mathrm{NCH}_{2}$ ), 51.33 ( $\mathrm{s}, \mathrm{NCH}_{2}$, piperidine), ( $\mathrm{C} \equiv \mathrm{C}$ not observed).

NMR ${ }^{1}$ H 7ed

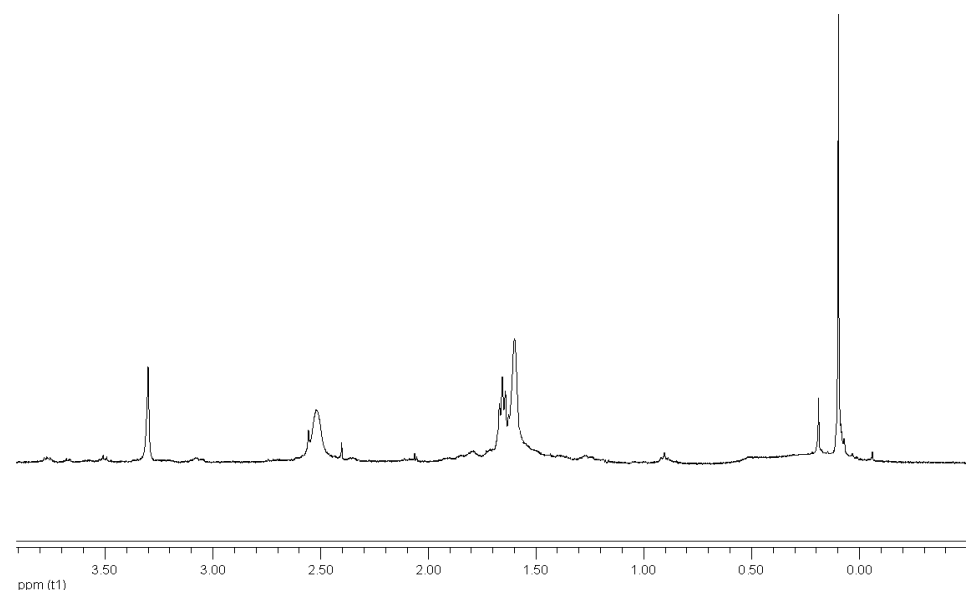

NMR ${ }^{13} \mathbf{C}\left\{{ }^{1} H\right\}: 7 e d$ 

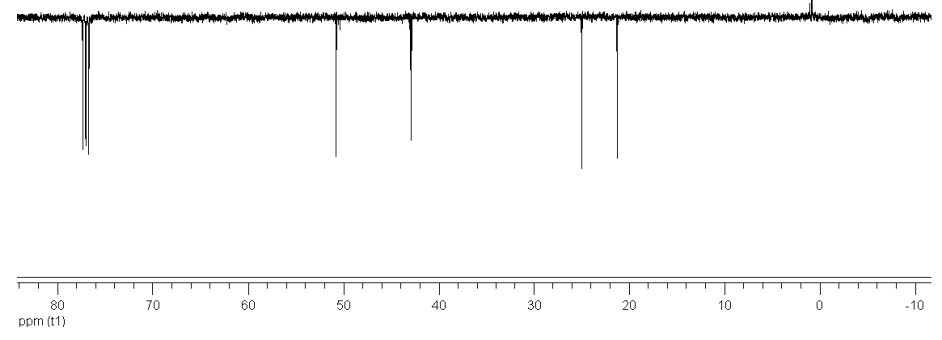

${ }_{8 a d} \overbrace{\mathrm{Me}_{2} \mathrm{NiMe}}$

$\mathrm{C}_{9} \mathrm{H}_{19} \mathrm{NSi}$ (169.34); MS(ESI +): $170(70 \%)[\mathrm{M}]^{+} .{ }^{1} \mathrm{H}$ NMR (400 MHz, $\left.\mathrm{CDCl}_{3}\right): \delta=0.01\left(\mathrm{~s}, 9 \mathrm{H}, \mathrm{SiMe}_{3}\right)$, 1.35 (d, 3H, $\left.\mathrm{CH}_{3}-\mathrm{CH},{ }^{3} \mathrm{~J}_{\mathrm{HH}}=7.0\right), 2.37\left(\mathrm{~s}, 6 \mathrm{H}, \mathrm{NCH}_{3}\right), 3.66\left(\mathrm{q}, 1 \mathrm{H}, \mathrm{CH}_{3}-\mathrm{CH},{ }^{3} \mathrm{~J}_{\mathrm{HH}}=7.0\right) .{ }^{13} \mathrm{C}\left\{{ }^{1} \mathrm{H}\right\}$ NMR (400 MHz, $\left.\mathrm{CDCl}_{3}\right): \delta=0.02\left(\mathrm{~s}, \mathrm{SiMe}_{3}\right), 18.86\left(\mathrm{~s}, \mathrm{CH}_{3}\right), 40.22\left(\mathrm{~s}, \mathrm{NMe}_{2}\right), 53.06(\mathrm{~s}, \mathrm{CH})$.

NMR ${ }^{1} \mathrm{H}: 7 \mathbf{a d}+\mathbf{8 a d}$
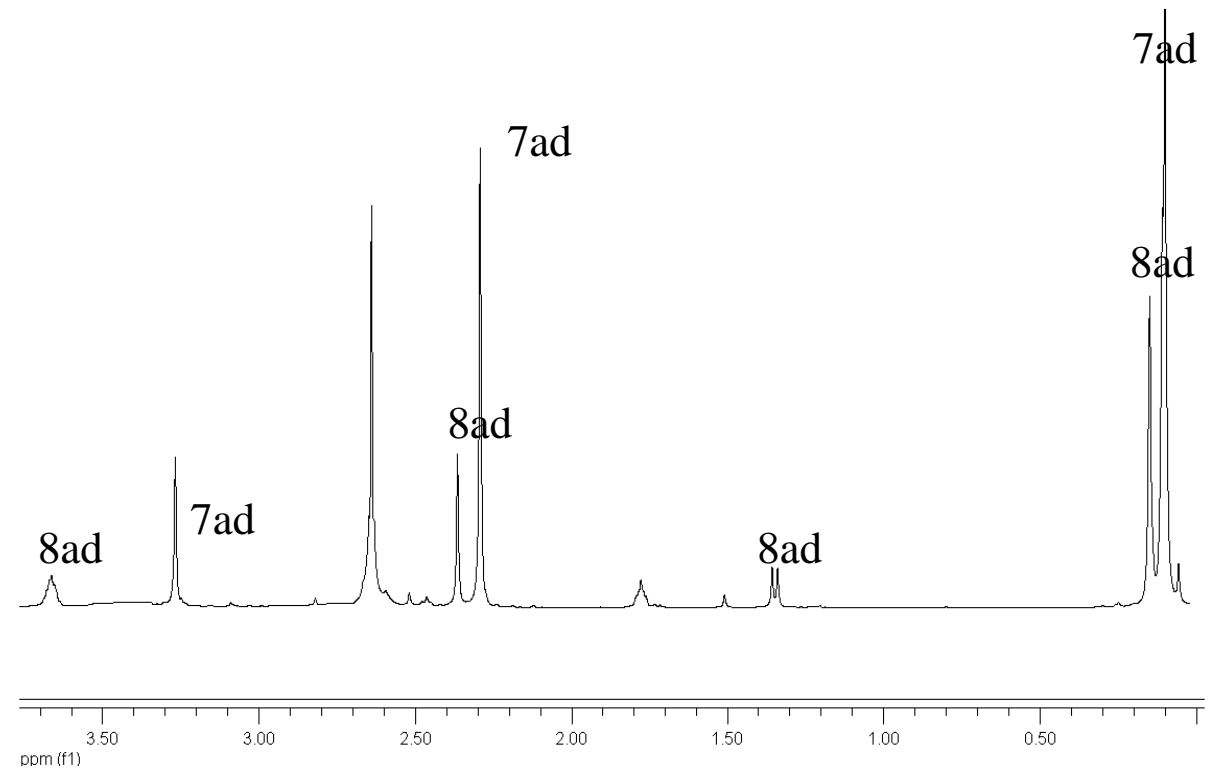

NMR ${ }^{13} \mathbf{C}\left\{{ }^{1} \mathbf{H}\right\}: 7 \mathbf{a d}+\mathbf{8 a d}$ 


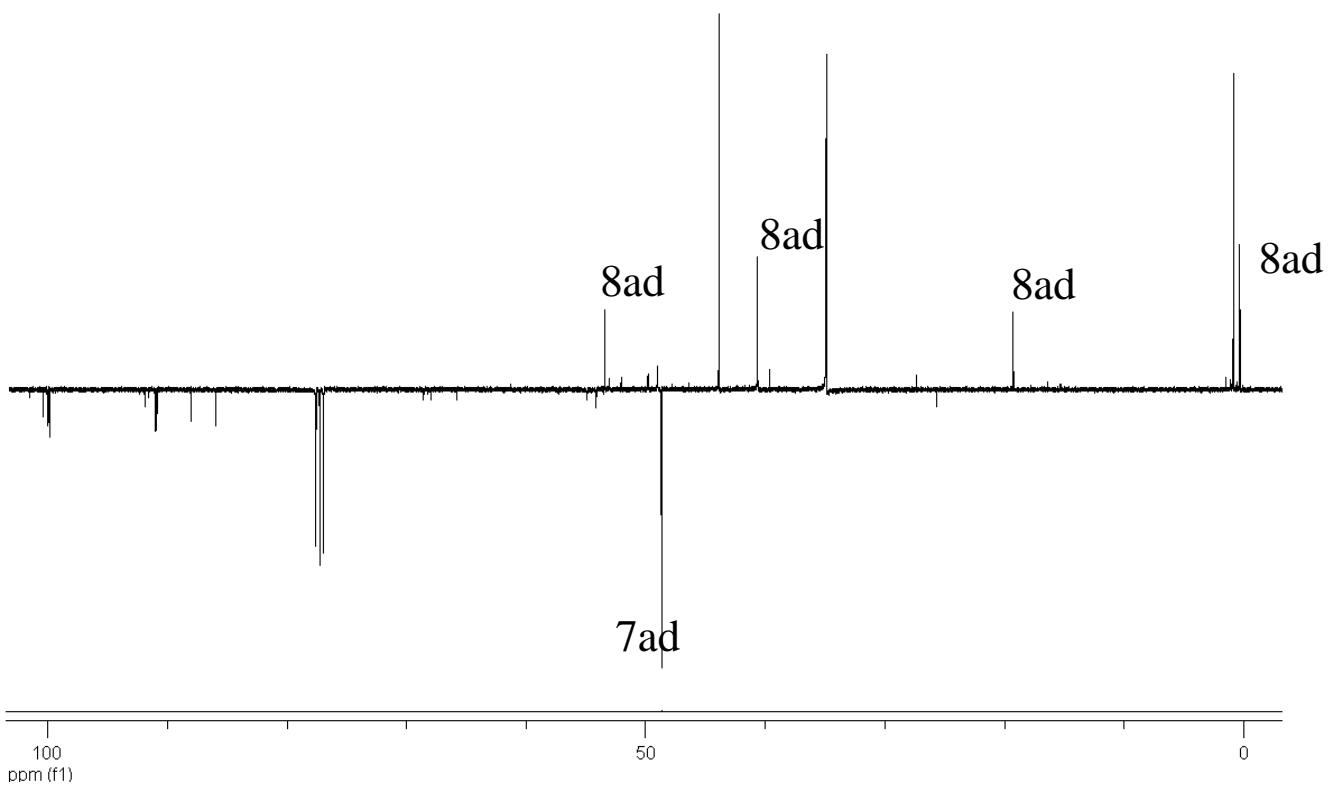

${ }_{\text {bd }}$

Eluents: n-hexane/ $\mathrm{Et}_{2} \mathrm{O}$ (90:10). Anal. Calc. para $\mathrm{C}_{15} \mathrm{H}_{31} \mathrm{NSi}$ (253.5): C, 71.07; H, 12.33; N, 5.53; Encontrado: C, 70.78; H, 11.94; N, 5.01. MS(ESI +): $254(100 \%)[\mathrm{M}]^{+} .{ }^{1} \mathrm{H}$ NMR $\left(400 \mathrm{MHz}, \mathrm{CDCl}_{3}\right): \delta=$ 0.15 (s, 9H, $\left.\mathrm{SiMe}_{3}\right), 0.91$ (t, 6H, $\left.\mathrm{CH}_{3},{ }^{n} \mathrm{Bu},{ }^{3} \mathrm{~J}_{\mathrm{HH}}=7.2\right), 1.27$ (d, 3H, $\left.\mathrm{CH}_{3}-\mathrm{CH},{ }^{3} \mathrm{~J}_{\mathrm{HH}}=7.1\right), 1.31-1.47(\mathrm{~m}$, $\left.8 \mathrm{H}, \mathrm{CH}_{2},{ }^{n} \mathrm{Bu}\right), 2.28-2.36\left(\mathrm{~m}, 2 \mathrm{H}, \mathrm{CH}_{2},{ }^{n} \mathrm{Bu}\right), 2.44-2.54\left(\mathrm{~m}, 2 \mathrm{H}, \mathrm{CH}_{2},{ }^{n} \mathrm{Bu}\right), 3.61\left(\mathrm{q}, 1 \mathrm{H}, \mathrm{CH}_{3}-\mathrm{CH},{ }^{3} \mathrm{~J}_{\mathrm{HH}}=\right.$ 7.0). ${ }^{13} \mathrm{C}\left\{{ }^{1} \mathrm{H}\right\} \operatorname{NMR}\left(400 \mathrm{MHz}, \mathrm{CDCl}_{3}\right): \delta=0.24\left(\mathrm{~s}, \mathrm{SiMe}_{3}\right), 14.10\left(\mathrm{~s}, \mathrm{CH}_{3},{ }^{n} \mathrm{Bu}\right), 20.05\left(\mathrm{~s}, \mathrm{CH}_{3}\right), 20.69$ (s, $\left.\mathrm{CH}_{2},{ }^{n} \mathrm{Bu}\right), 30.70$ (s, $\left.\mathrm{CH}_{2},{ }^{n} \mathrm{Bu}\right), 48.80$ (s, $\left.\mathrm{CH}\right), 50.95$ (s, $\left.\mathrm{CH}_{2},{ }^{n} \mathrm{Bu}\right), 87.51$ (s, $\left.\mathrm{C} \equiv \mathrm{C}\right), 106.52$ (s, $\left.\mathrm{C} \equiv \mathrm{C}\right)$.

\section{NMR ${ }^{1} \mathbf{H} 8 b d$}

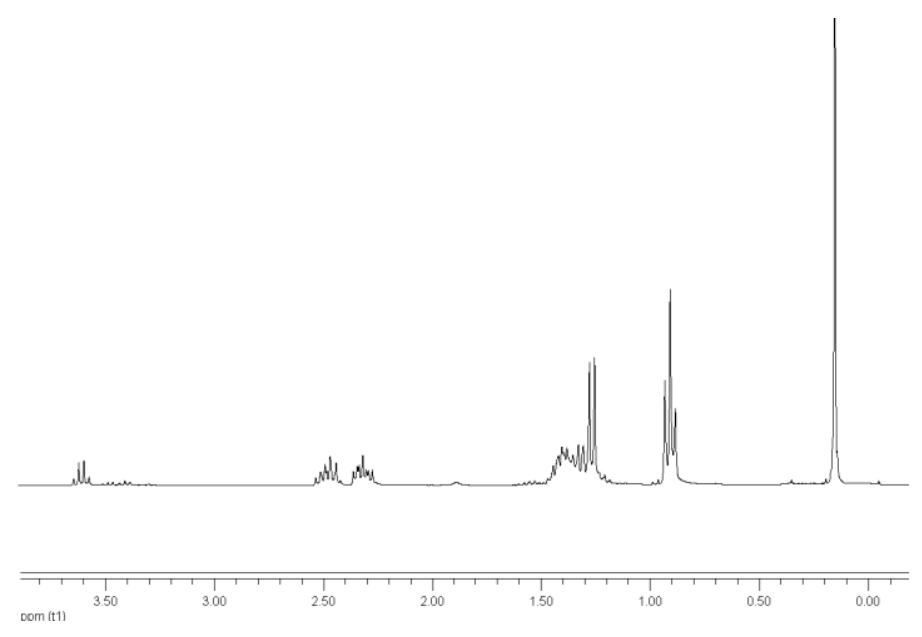

$\mathrm{NMR}{ }^{13} \mathrm{C}\left\{{ }^{1} \mathrm{H}\right\}$ 8bd 


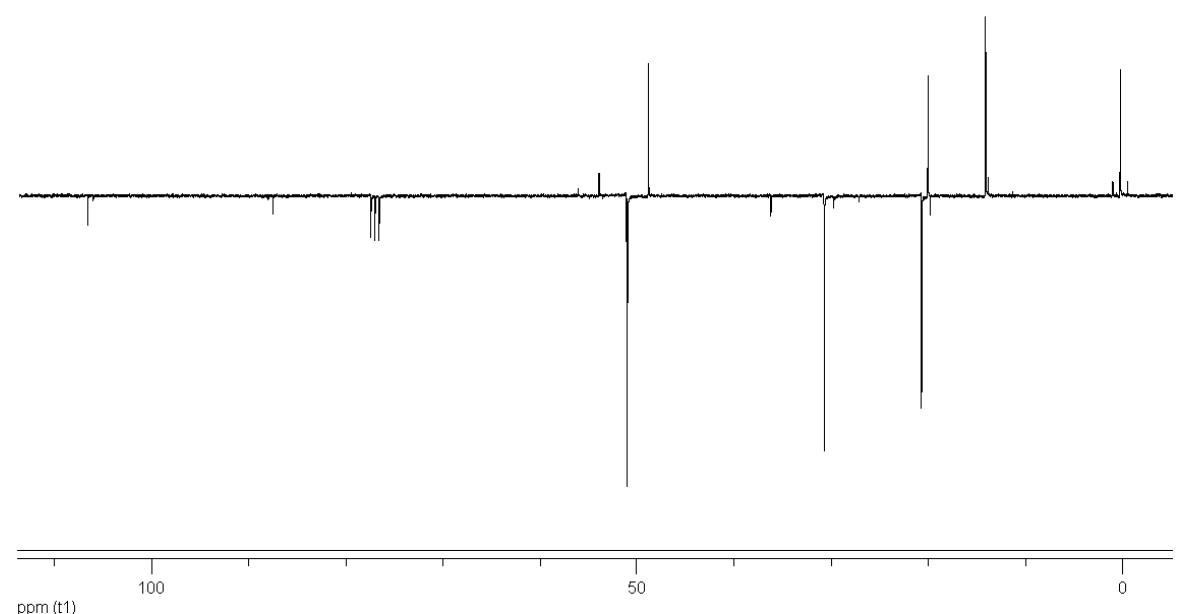

$\operatorname{pom}(11)$

8cd

$\mathrm{C}_{19} \mathrm{H}_{39} \mathrm{NSi}$ (309.61). ${ }^{1} \mathrm{H}$ NMR (400 $\left.\mathrm{MHz}, \mathrm{CDCl}_{3}\right): \delta=0.08$ (s, 9H, SiMe $)_{3}$ ), $0.70\left(t, 6 \mathrm{H}, \mathrm{CH}_{3}, \mathrm{n}-\mathrm{hexyl}\right.$, $\left.{ }^{3} \mathrm{~J}_{\mathrm{HH}}=7.0\right), 1.25-1.40\left(\mathrm{~m}, 23 \mathrm{H}, 3 \mathrm{H}, \mathrm{CH}_{3}-\mathrm{CH}+20 \mathrm{H}, \mathrm{n}-\mathrm{hexyl}\right), 3.29\left(\mathrm{q}, 1 \mathrm{H}, \mathrm{CH}_{3^{-}} \mathrm{CH},{ }^{3} \mathrm{~J}_{\mathrm{HH}}=7.0\right)$.

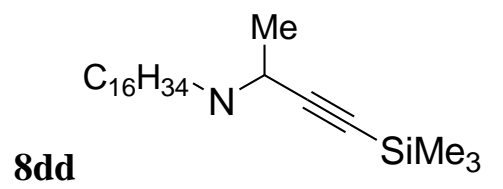

$\mathrm{C}_{23} \mathrm{H}_{47} \mathrm{NSi}$ (365.71). ${ }^{1} \mathrm{H}$ NMR (400 MHz, $\left.\mathrm{CDCl}_{3}\right): \delta=0.06$ (s, 9H, SiMe $)_{3}$, 0.77 (t, 6H, $\mathrm{CH}_{3}$, n-octyl, $\left.{ }^{3} \mathrm{~J}_{\mathrm{HH}}=7.4\right)$, 1.19-1.30 (m, 31H, 3H, $\mathrm{CH}_{3}-\mathrm{CH}+28 \mathrm{H}$, n-octyl), $3.56\left(\mathbf{q}, 1 \mathrm{H}, \mathrm{CH}_{3}-\mathrm{CH},{ }^{3} \mathrm{~J}_{\mathrm{HH}}=7.2\right)$. 
3. Preliminary results for the syntheses of selected propragylamines before optimization of reaction conditions for selected gold compounds and NP. Influence of the excess of amine

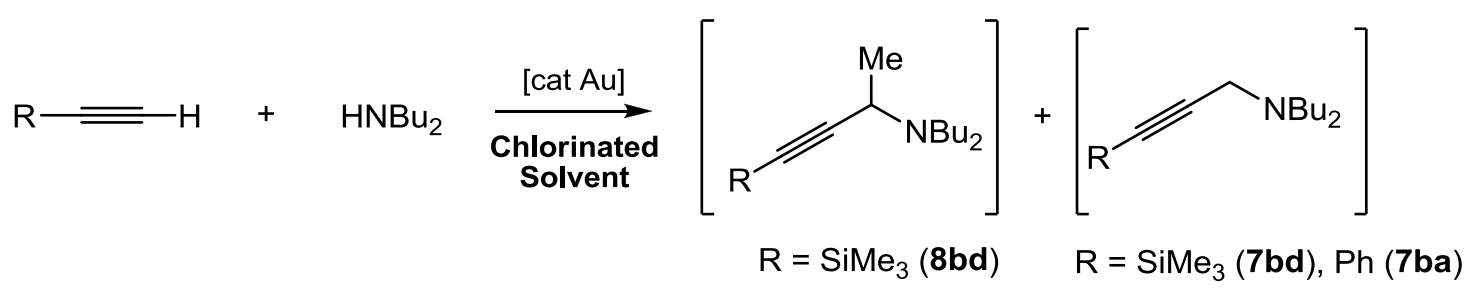

Scheme 1 SI. Formation of $7 \mathrm{ba}, 7 \mathrm{bd}, 8 \mathrm{bd}$ in chlorinated solvents

Table 1SI. Catalytic conversions for the preparation of propargylamines $7 \mathbf{b a}, \mathbf{7 b d}$ and $\mathbf{8 b d}$.

\begin{tabular}{|c|c|c|c|c|c|}
\hline Cat & $\begin{array}{c}\text { Yield }^{[\mathrm{a}]} \mathbf{8 b d} \\
\text { in } \mathrm{CHCl}_{3}\end{array}$ & $\begin{array}{l}\text { Yield }^{[\mathrm{a}]} 8 \mathrm{bd} \\
\text { in }\left(\mathrm{ClCH}_{2}\right)_{2}\end{array}$ & $\begin{array}{l}\text { Yield }^{[\mathrm{a}]} \\
\text { 8bd/7bd } \\
\text { In DCM }\end{array}$ & $\begin{array}{c}\text { Molar ratio }^{[\mathrm{b}]} \\
\text { 8bd/7bd in } \\
\text { DCM }\end{array}$ & Yield $^{[\mathrm{a}]} 7 \mathrm{ba}$ in DCM \\
\hline $\mathbf{1}^{\mathrm{c}}(10 \mathrm{~mol} \%)$ & 91 & 95 & 95 & $0.5 / 1$ & 58 \\
\hline $\begin{array}{l}\mathrm{K}\left[\mathrm{AuCl}_{4}\right]^{\mathrm{c}} \\
(10 \mathrm{~mol} \%)\end{array}$ & 90 & 93 & 96 & $1 / 0.6$ & 65 \\
\hline $\begin{array}{l}\mathrm{K}\left[\mathrm{AuCl}_{4}\right]^{\mathrm{d}} \\
(10 \mathrm{~mol} \%)\end{array}$ & --- & --- & 93 & $1 / 0.5$ & 70 \\
\hline $\begin{array}{l}\mathrm{K}\left[\mathrm{AuCl}_{4}\right]^{\mathrm{e}} \\
(5 \mathrm{~mol} \%)\end{array}$ & --- & --- & --- & --- & 71 \\
\hline $\begin{array}{l}\mathrm{K}\left[\mathrm{AuCl}_{4}\right]^{\mathrm{f}} \\
(5 \mathrm{~mol} \%)\end{array}$ & --- & --- & 85 & $0.1 / 1$ & 81 \\
\hline $\begin{array}{l}\mathrm{K}\left[\mathrm{AuCl}_{4}\right]^{\mathrm{g}} \\
(1 \mathrm{~mol} \%)\end{array}$ & --- & --- & 91 & $0.08 / 1$ & 83 \\
\hline $\mathbf{1}^{\mathrm{g}}(1 \mathrm{~mol} \%)$ & --- & --- & 90 & $0.05 / 1$ & 75 \\
\hline $\begin{array}{l}\text { Nano-12 }^{c} \\
(10 \mathrm{~mol} \%)\end{array}$ & --- & --- & 94 & $1 / 0.5$ & 75 \\
\hline $\begin{array}{l}\text { Nano-12 }^{g} \\
(1 \mathrm{~mol} \%)\end{array}$ & --- & --- & 90 & $0.05 / 1$ & 76 \\
\hline
\end{tabular}

[a] Isolated yields. [b] NMR. [c] $10 \%$ mol catalyst, $5 \mathrm{~mL}$ solvent, $50{ }^{\circ} \mathrm{C}, 24 \mathrm{~h}, 1 / 1$ alkyne/amine. [d] $10 \%$ mol catalyst, $5 \mathrm{~mL}$ solvent, $50{ }^{\circ} \mathrm{C}, 24 \mathrm{~h}, 1 / 1.2$ alkyne/amine. [e] $5 \%$ mol catalyst, $5 \mathrm{~mL}$ solvent, $100{ }^{\circ} \mathrm{C}, 24 \mathrm{~h}, 1 / 1.2$ alkyne/amine. [f] $5 \%$ mol catalyst, $5 \mathrm{~mL}$ solvent, $50{ }^{\circ} \mathrm{C}, 48 \mathrm{~h}, 1 / 1.2$ alkyne/amine. [g] $1 \% \mathrm{~mol} \mathrm{catalyst,} 5 \mathrm{~mL}$ solvent, $50{ }^{\circ} \mathrm{C}, 72 \mathrm{~h}, 1 / 1.2$ alkyne/amine. 


\section{$\underline{\text { 4. Experiments with deuterated DCM, } \mathrm{CD}_{2}} \underline{\mathrm{Cl}}_{2} \underline{\text { to obtain } 7 \mathrm{ba}-\mathrm{d}_{2}} \underline{\underline{2} \text { and selected NMR and MS spectra }}$}

To a solution of $2 \mathrm{mmol}$ of $\mathrm{Bu}_{2} \mathrm{NH}(\mathbf{5 a})$ in $5 \mathrm{~mL}$ of $\mathrm{CDCl}_{2}, \mathrm{~K}\left[\mathrm{AuCl}_{4}\right]$ is added $(5 \mathrm{~mol} \%)$. Then phenylacetylene $(6 \mathbf{b}, 2 \mathrm{mmol})$ is added to the resulting mixture which is allowed to stir at $50^{\circ} \mathrm{C}$ during 24 h. Subsequent filtration through celite and complete removal of the solvent gave a crude mixture that

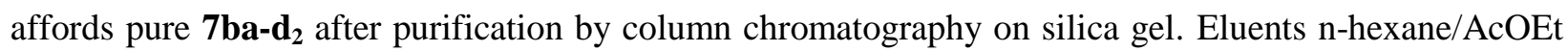
(95:5). Yield: $60 \% . \mathrm{C}_{17} \mathrm{H}_{23} \mathrm{D}_{2} \mathrm{~N}$ (245.44). MS(ESI +): $246(100 \%)[\mathrm{M}]^{+}$. Spectra in figure 2 (manuscript) and below.

$7 \mathrm{ba}^{-d_{2}}$<smiles>[2H]C([2H])(C#CPc1ccccc1)N(CC)CC(C)(C)C</smiles>

NMR ${ }^{1} \mathrm{H}$ of $\mathbf{7 b a}$
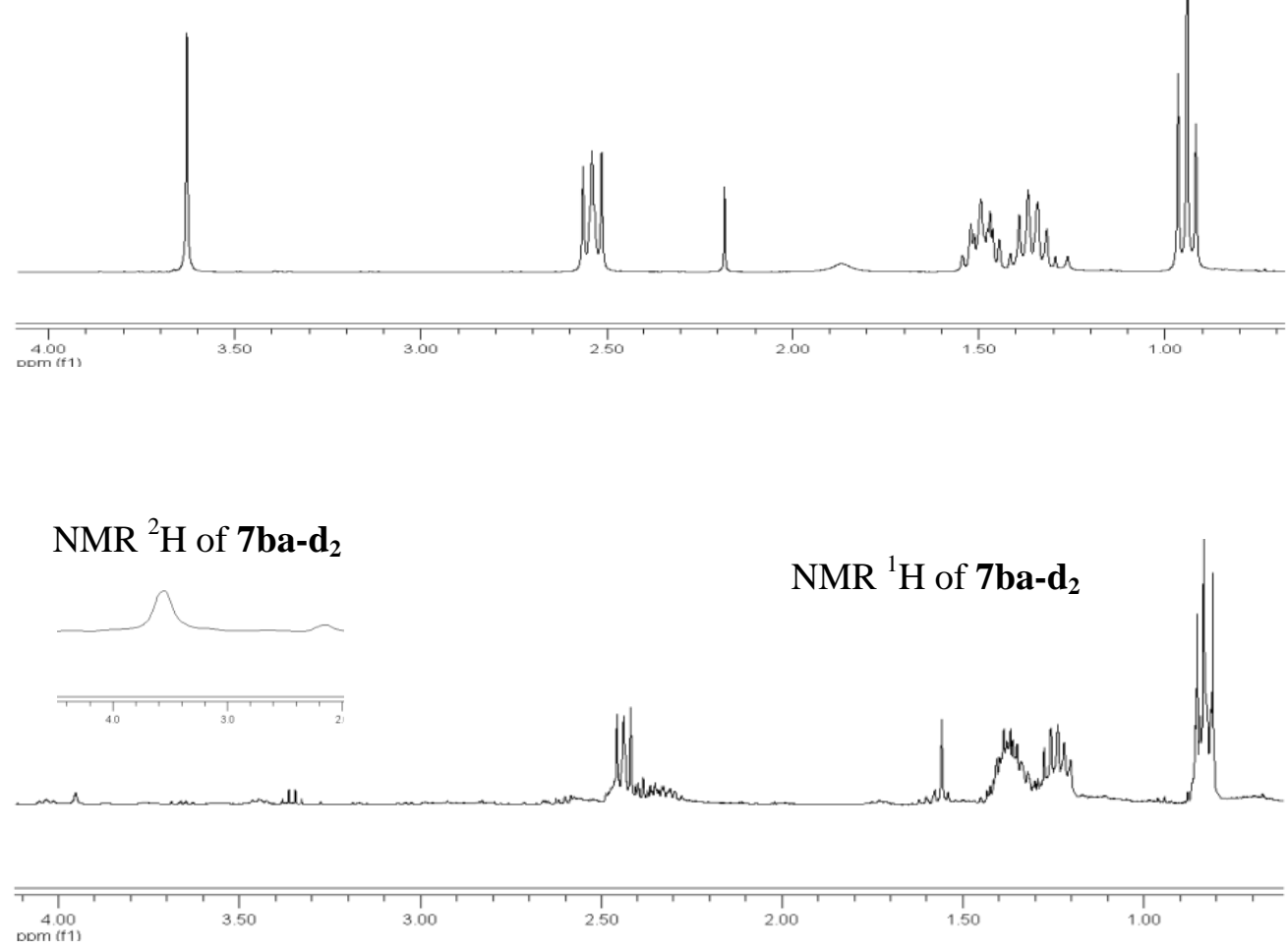
ESI $^{+}$7ba-d 2

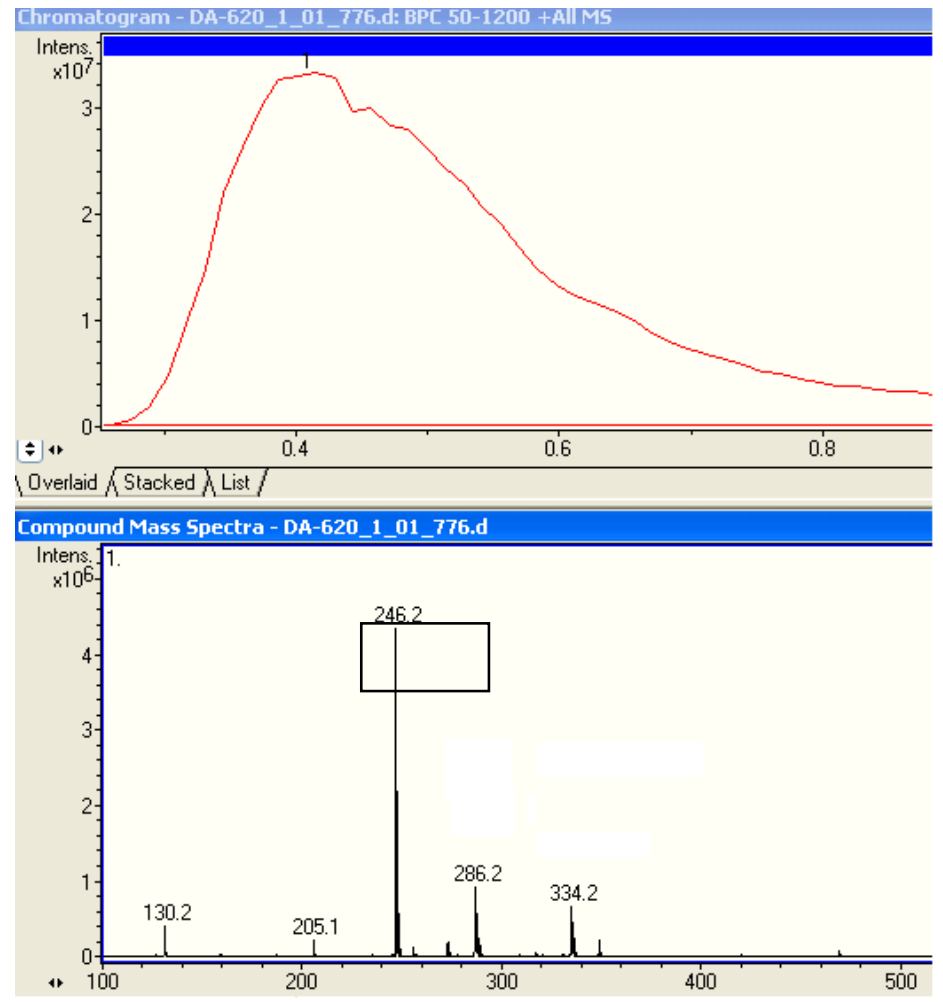

\section{$\underline{\text { 5. Reaction with } \mathrm{CH}_{2}} \underline{\mathrm{Br}}_{2} \underline{\text { to obtain } 7 \mathrm{ba} \text { and selected NMR spectra }}$}

To a solution of $2.4 \mathrm{mmol}$ of $\mathrm{Bu}_{2} \mathrm{NH}(\mathbf{5 a})$ in $5 \mathrm{~mL}$ of $\mathrm{CH}_{2} \mathrm{Br}_{2}, \mathrm{~K}\left[\mathrm{AuCl}_{4}\right](5 \mathrm{~mol} \%)$ is added and then phenylacetylene $(\mathbf{6 b}, 2 \mathrm{mmol})$ is added. The resulting mixture is allowed to stir at $50^{\circ} \mathrm{C}$ during $24 \mathrm{~h}$. Subsequent filtration through celite and complete removal of the solvent gives a crude mixture that affords final product $\mathbf{7 b a}$ after purification by column chromatography on silica gel. Eluents nhexane/AcOEt (95:5). Yield: $73 \%$. NMR spectra below. 
Comparison on the formation of $7 \mathrm{ba}$ after $2 \mathrm{~h}$ when $\mathrm{CH}_{2} \mathrm{Br}_{2}$ is used instead of $\mathrm{CH}_{2} \mathrm{Cl}_{2}$. The formation of $7 \mathbf{b a}$ is significantly faster with $\mathrm{CH}_{2} \mathrm{Br}_{2}$ after $2 \mathrm{~h}$.

NMR ${ }^{1} \mathrm{H}: \mathrm{CH}_{2} \mathrm{Br}_{2} 2 \mathrm{~h}$ of reaction

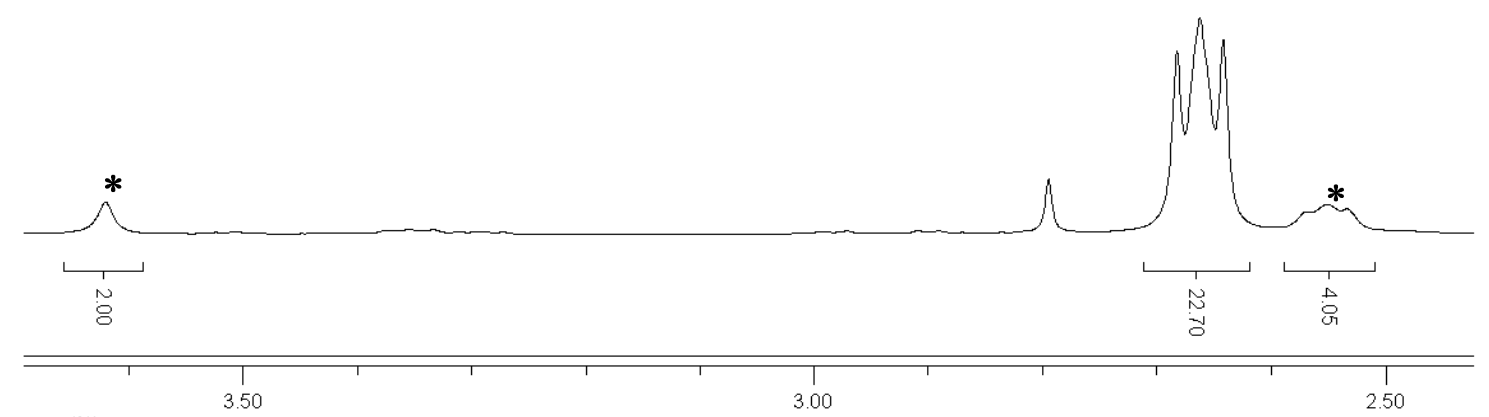

$\operatorname{ppm}(\mathrm{f} 1)$

NMR ${ }^{1} \mathrm{H}: \mathrm{CH}_{2} \mathrm{Cl}_{2} 2$ h of reaction

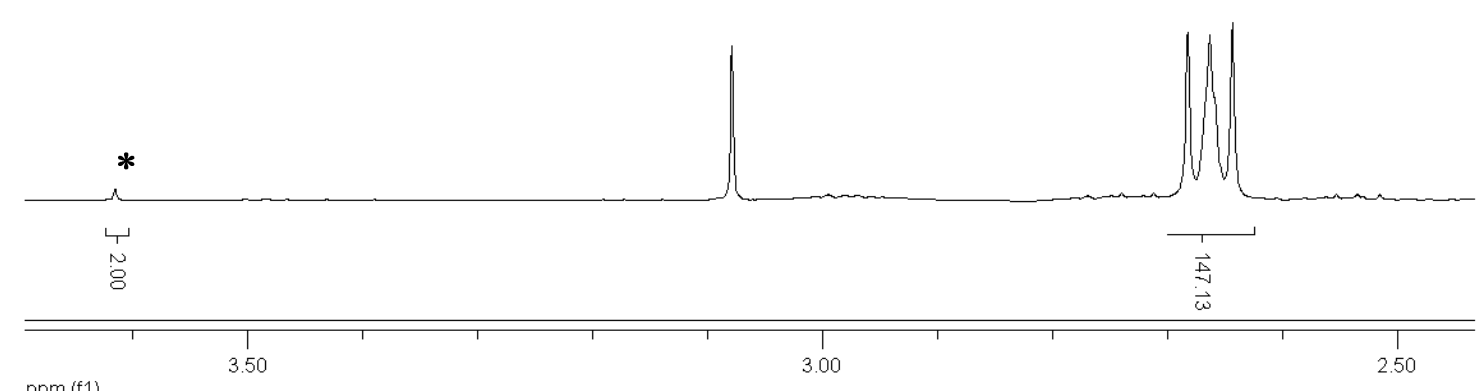

$\operatorname{ppm}(\mathrm{f} 1)$<smiles>CCCCNCC#CPc1ccccc1</smiles>

$7 \mathbf{b a}$ 
6. Gold-catalyzed cross-coupling reaction of $\mathrm{Bu}_{2} \mathrm{NH}(5 \mathrm{~b})$ with two different alkynes (trimethylsilylacetylene 6d and phenylacetylene 6a) in DCM

To a solution of $3.1 \mathrm{mmol}$ of $\mathrm{Bu}_{2} \mathrm{NH}(\mathbf{5 a})$ in $5 \mathrm{~mL}$ of $\mathrm{CH}_{2} \mathrm{Br}_{2}, \mathrm{~K}\left[\mathrm{AuCl}_{4}\right]$ (5 mol\%) is added and then phenylacetylene $(6 \mathbf{6}, 1.6 \mathrm{mmol})$ and trimethylsilylacetylene $(\mathbf{6 d}, 1.6 \mathrm{mmol})$ are added as well. The resulting mixture is allowed to stir at $50^{\circ} \mathrm{C}$ during $24 \mathrm{~h}$. Subsequent filtration through celite and complete removal of the solvent gives a crude mixture that affords products $\mathbf{7 b a}, \mathbf{7 b d}, \mathbf{8 b d}$ and $\mathbf{1 3}$ after purification by column chromatography on silica gel. Eluents n-hexane/AcOEt (80:20).

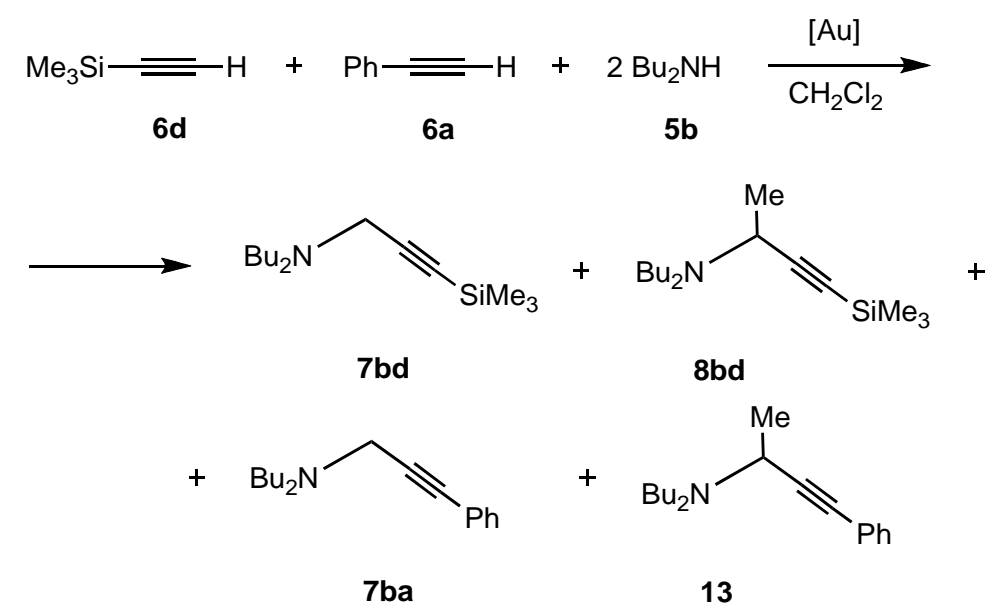

Yields: 7ba (4\%), $\mathbf{7 b d}(41 \%)$ and $\mathbf{8 b d}(40 \%)$.

13<smiles>CCCCNC(C)C#Cc1ccccc1</smiles>

Eluents n-hexane/AcOEt (80:20). $\mathrm{C}_{18} \mathrm{H}_{27} \mathrm{~N}$ (257.41); MS(ESI +): $240(100 \%)[\mathrm{M}]^{+} .{ }^{1} \mathrm{H}$ NMR (400 MHz, $\left.\mathrm{CDCl}_{3}\right): \delta=1.06\left(\mathrm{t}, 6 \mathrm{H}, \mathrm{CH}_{3},{ }^{n} \mathrm{Bu},{ }^{3} \mathrm{~J}_{\mathrm{HH}}=7.1\right), 1.40\left(\mathrm{~d}, 3 \mathrm{H}, \mathrm{CH}_{3}-\mathrm{CH},{ }^{3} \mathrm{~J}_{\mathrm{HH}}=7.0\right), 1.43-1.53\left(\mathrm{~m}, 8 \mathrm{H}, \mathrm{CH}_{2}\right.$, $\left.{ }^{n} \mathrm{Bu}\right), 2.45-2.53\left(\mathrm{~m}, 2 \mathrm{H}, \mathrm{CH}_{2},{ }^{n} \mathrm{Bu}\right), 2.58-2.66\left(\mathrm{~m}, 2 \mathrm{H}, \mathrm{CH}_{2},{ }^{n} \mathrm{Bu}\right), 3.88$ (q, $1 \mathrm{H}, \mathrm{CH}_{3}-\mathrm{CH},{ }^{3} \mathrm{~J}_{\mathrm{HH}}=7.0$ ), 7.38$7.40\left(\mathrm{~m}, 3 \mathrm{H}, \mathrm{H}_{\mathrm{p}}+\mathrm{H}_{\mathrm{m}}, \mathrm{Ph}\right), 7.55\left(\mathrm{~d}, 2 \mathrm{H}, \mathrm{H}_{\mathrm{o}}, \mathrm{Ph},{ }^{3} \mathrm{~J}_{\mathrm{HH}}=7.4\right) .{ }^{13} \mathrm{C}\left\{{ }^{1} \mathrm{H}\right\}$ NMR $\left(400 \mathrm{MHz}, \mathrm{CDCl}_{3}\right): \delta=13.91$ (s, $\mathrm{CH}_{3},{ }^{n} \mathrm{Bu}$ ), 20.30 (s, $\mathrm{CH}_{3}$ ), 20.64 (s, $\left.\mathrm{CH}_{2},{ }^{n} \mathrm{Bu}\right), 30.90$ (s, $\left.\mathrm{CH}_{2},{ }^{n} \mathrm{Bu}\right), 51.57$ (s, $\left.\mathrm{CH}_{2},{ }^{n} \mathrm{Bu}\right), 55.99$ (s, $\left.\mathrm{CH}\right)$, 131.62 (s, $\left.\mathrm{C}_{\mathrm{p}}, \mathrm{Ph}\right), 131.69$ (s, $\left.\mathrm{C}_{\mathrm{m}}, \mathrm{Ph}\right), 132.51$ (s, $\mathrm{C}_{\mathrm{o}}, \mathrm{Ph}$ ). 
NMR ${ }^{1} \mathrm{H}$ cross-coupling experiment
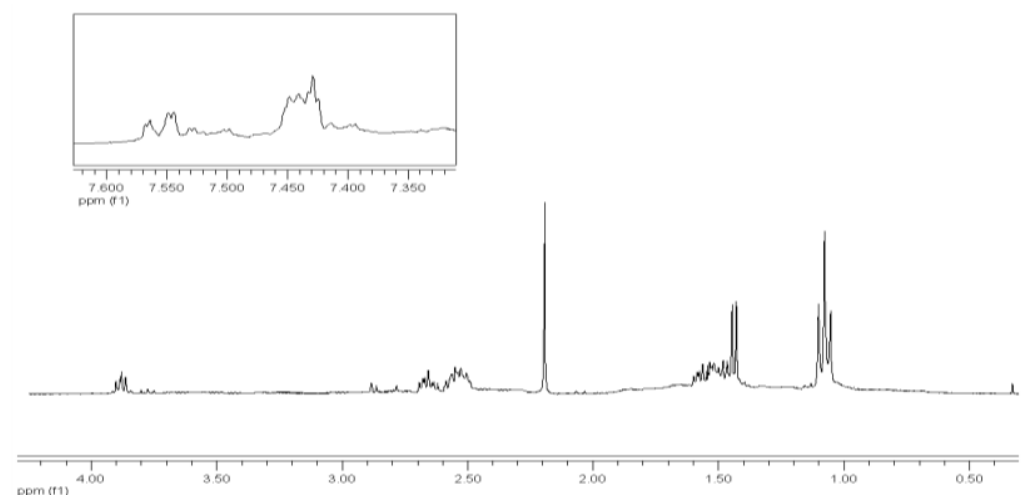

\section{$\mathrm{ESI}^{+}$cross-coupling experiment}

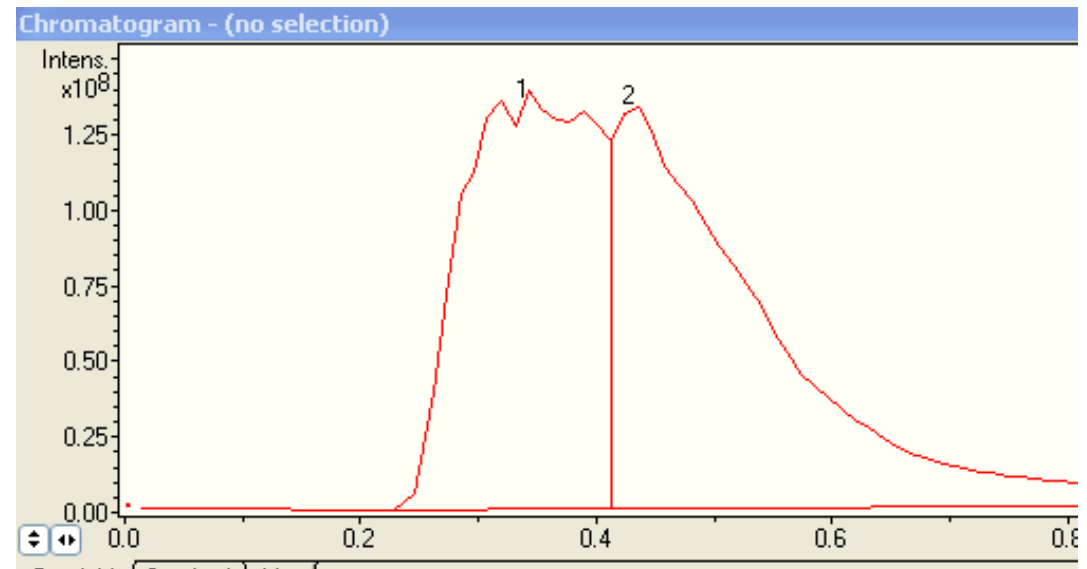

Overlaid Stacked $\lambda$ List

Compound Mass Spectra - DA-678_32_01_1732.d

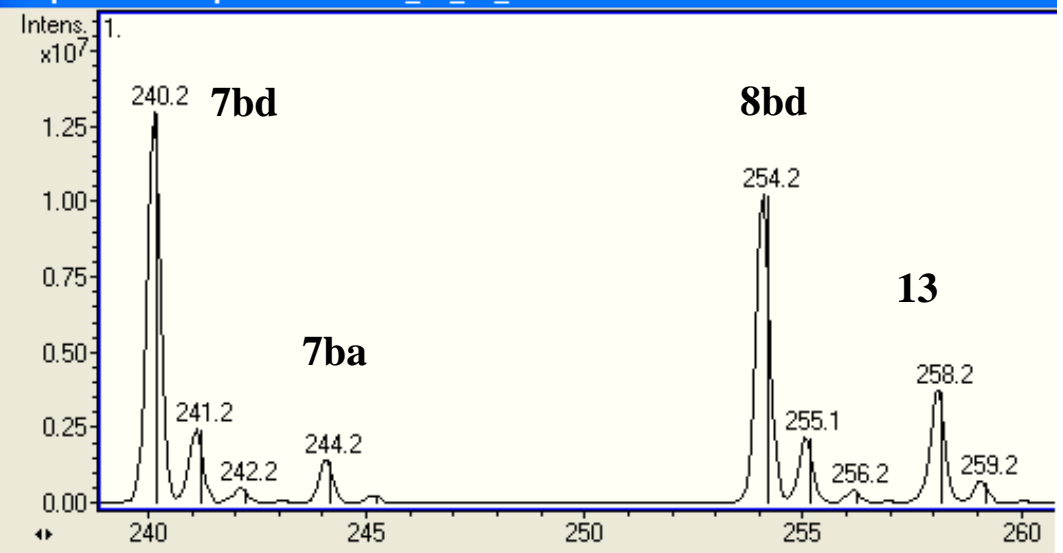




\section{$\underline{\text { 7. Experiments with }{ }^{13} \mathrm{C} \text { enriched trimethylsilylacetylene }{ }^{13} \mathrm{C}-6 \mathrm{~d} \text { to obtain }{ }^{13} \mathrm{C}-8 \mathrm{bd}}$}

To a solution of $1 \mathrm{mmol}$ of $\mathrm{Bu}_{2} \mathrm{NH}(5 \mathbf{a})$ in $5 \mathrm{~mL}$ of $\mathrm{CH}_{2} \mathrm{Br}_{2}, \mathrm{~K}$ [ $\left.\mathrm{AuCl}_{4}\right](5 \mathrm{~mol} \%$ ) is added and then 1 mmol of ${ }^{13} \mathrm{C}$ enriched trimethylsilylacetylene is added. The resulting mixture is allowed to stir at $50{ }^{\circ} \mathrm{C}$ during $24 \mathrm{~h}$. Subsequent filtration through celite and complete removal of the solvent gives a crude mixture of products ${ }^{13} \mathbf{C}-7 \mathbf{b d}$ and ${ }^{13} \mathbf{C - 8 b d}$.

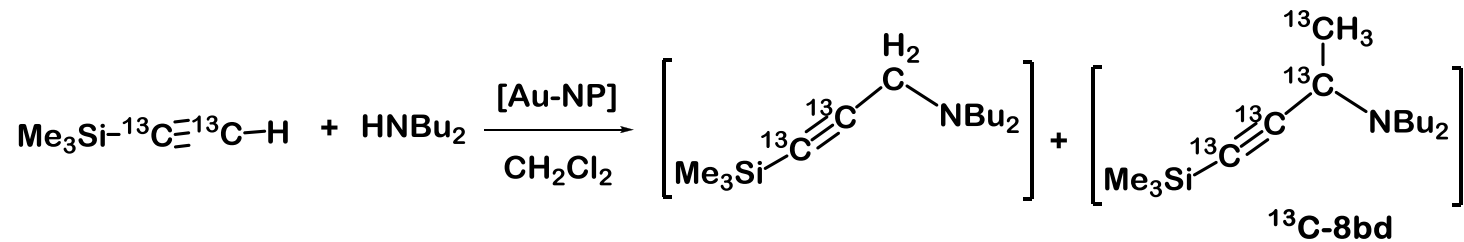

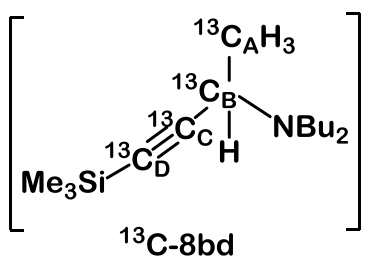

$$
\begin{array}{lll}
\delta\left(\mathrm{C}_{\mathrm{A}}\right)=20.00 \mathrm{ppm} & { }^{1} \mathrm{~J}_{\mathrm{CA}-\mathrm{CB}}=39.6 \mathrm{~Hz} \\
\delta\left(\mathrm{C}_{\mathrm{B}}\right)=48.83 \mathrm{ppm} & { }^{1} \mathrm{~J}_{\mathrm{CB}-\mathrm{CC}}=60.7 \mathrm{~Hz} \\
\delta\left(\mathrm{C}_{\mathrm{C}}\right)=86.93 \mathrm{ppm} & { }^{1} \mathrm{~J}_{\mathrm{CC}-\mathrm{CD}}=122.0 \mathrm{~Hz} \\
\delta\left(\mathrm{C}_{\mathrm{D}}\right)=91.52 \mathrm{ppm} & { }^{1} \mathrm{~J}_{\mathrm{CB}-\mathrm{CD}}=6.1 \mathrm{~Hz}
\end{array}
$$

$\mathrm{NMR}{ }^{13} \mathrm{C}\left\{{ }^{1} \mathrm{H}\right\}$ of ${ }^{13} \mathbf{C}-\mathbf{8 b d}$
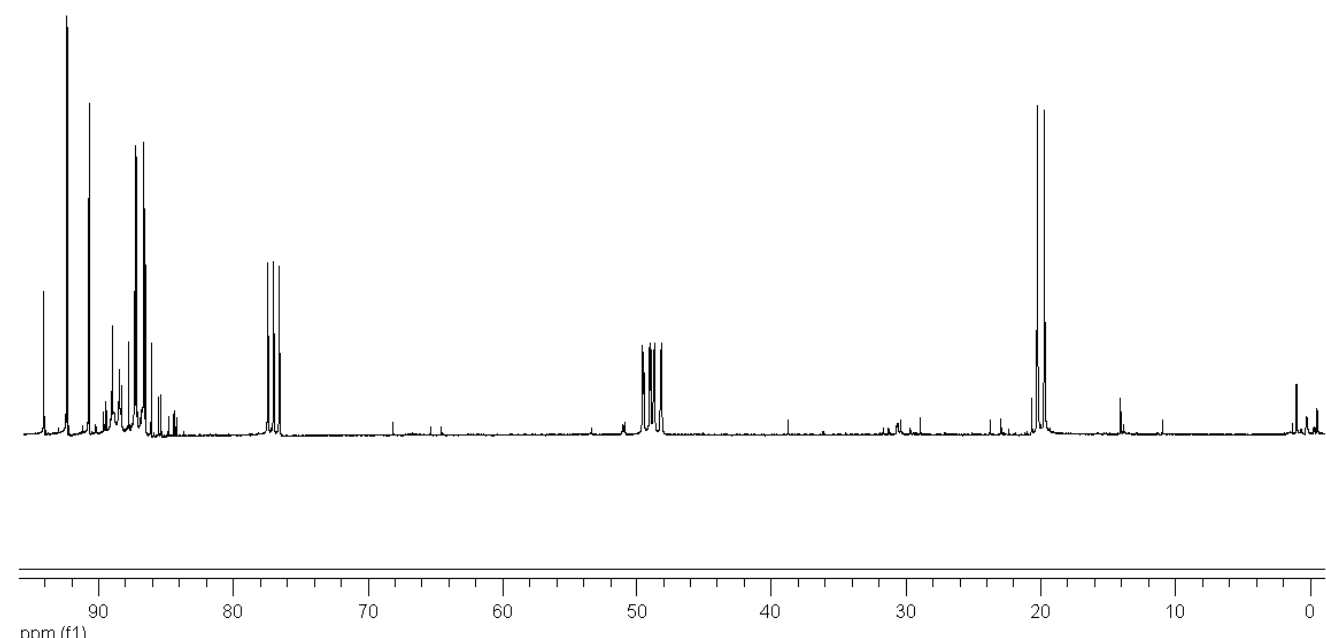

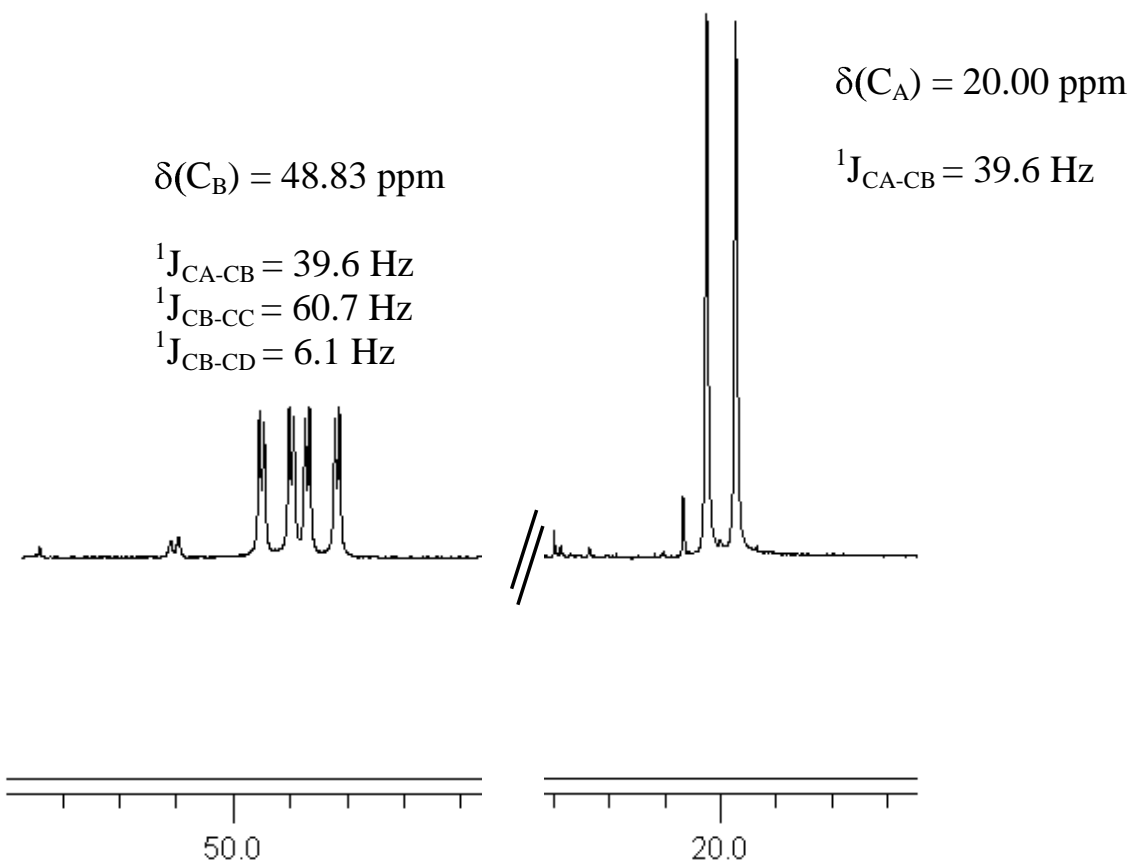

ppm (f1) 


\section{Preparation and Characterization of gold-nanoparticles (TEM and X-Ray Analysis, XPS in manuscript)}

\section{Nano-11}

A $1 \mathrm{~mL}$ aliquot of nano-11 generated from a solution of ${ }^{\mathrm{n}} \mathrm{Bu}_{2} \mathrm{NH}(2 \mathrm{mmol})$ in $5 \mathrm{~mL}$ of $\mathrm{CH}_{2} \mathrm{Cl}$ with $\mathrm{K}\left[\mathrm{AuCl}_{4}\right](5 \mathrm{~mol} \%$ ) (after stirring for $5 \mathrm{~min}$ at r.t.) was applied onto a glow discharged carbon coated copper grid and blotted. The specimen was imaged with a JEOL-2000FXII high-resolution transmission electron microscope (point to point resolution $0.28 \mathrm{~nm}$ ) and images were recorded on a Gatan MSC-794 camera, using the Digital Micrograph software (from Gatan)

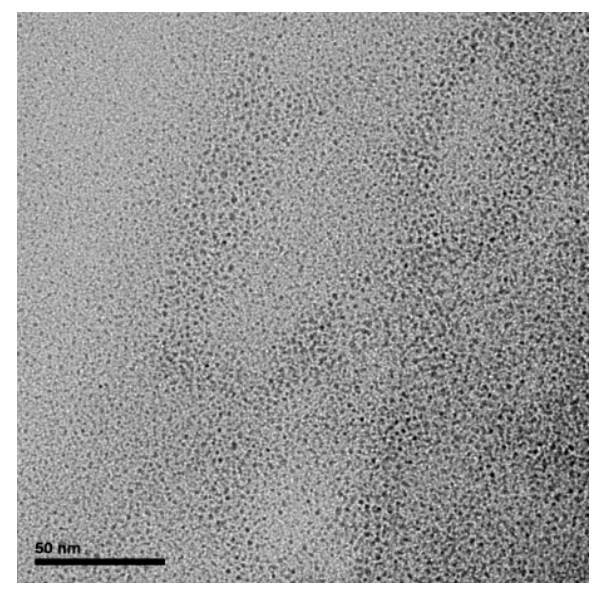

Fig SI 1. TEM field-view image at 250000X of nano-11.

\section{2}

A $1 \mathrm{~mL}$ aliquot of 22 generated from a solution of ${ }^{\mathrm{n}} \mathrm{Bu}_{2} \mathrm{NH}(2 \mathrm{mmol})$ in $5 \mathrm{~mL}$ of $\mathrm{CH}_{2} \mathrm{Cl}$ with [AuCl(tht)] ( $5 \mathrm{~mol} \%$ ) (after stirring for $5 \mathrm{~min}$ at $\mathrm{rt}$ ) was applied onto a glow discharged carbon coated copper grid and blotted. The specimen was imaged with a JEOL-2000FXII high-resolution transmission electron microscope (point to point resolution $0.28 \mathrm{~nm}$ ) and images were recorded on a Gatan MSC-794 camera, using the Digital Micrograph software (from Gatan). 


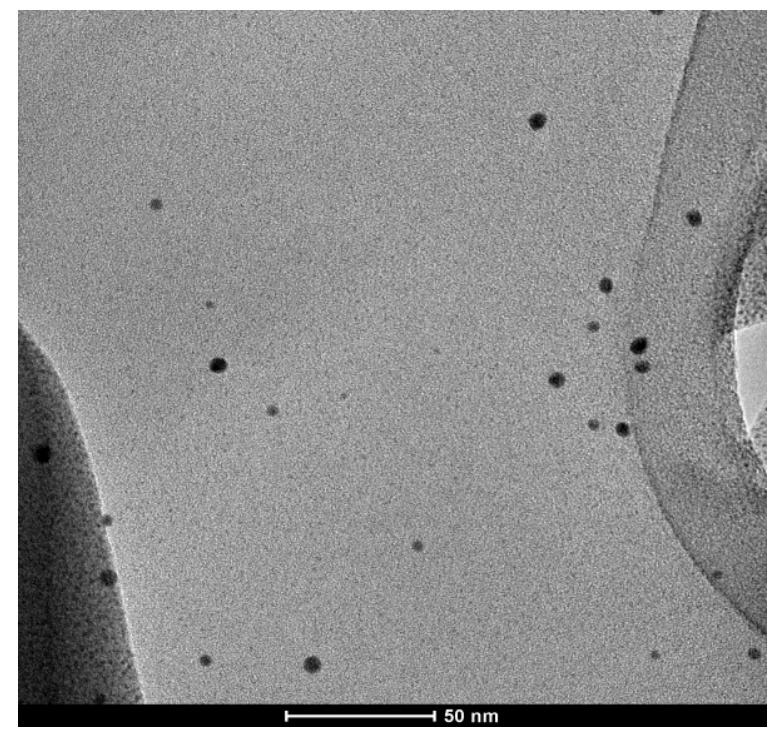

Fig SI 3. TEM field-view image at $250000 \mathrm{X}$ of $\mathbf{2 2}$. No appreciable number of Nps can be seen in this case.

\section{X-Ray Analysis of nano-11}

Step-scanned powder diffraction pattern was collected at room temperature using a Siemens D500/501 diffractometer with a $\mathrm{Cu}$ x-ray tube. The diffractometer was operated at $30 \mathrm{~mA}$ and $35 \mathrm{kV}$ and a graphite monochromator was used to select the $\mathrm{Cu} \mathrm{Ka1,2}$ radiation. Data were collected from $5^{\circ}$ up $80^{\circ}$ with a stepsize of $0.03^{\circ}$ and a counting rate of 2 s/step.

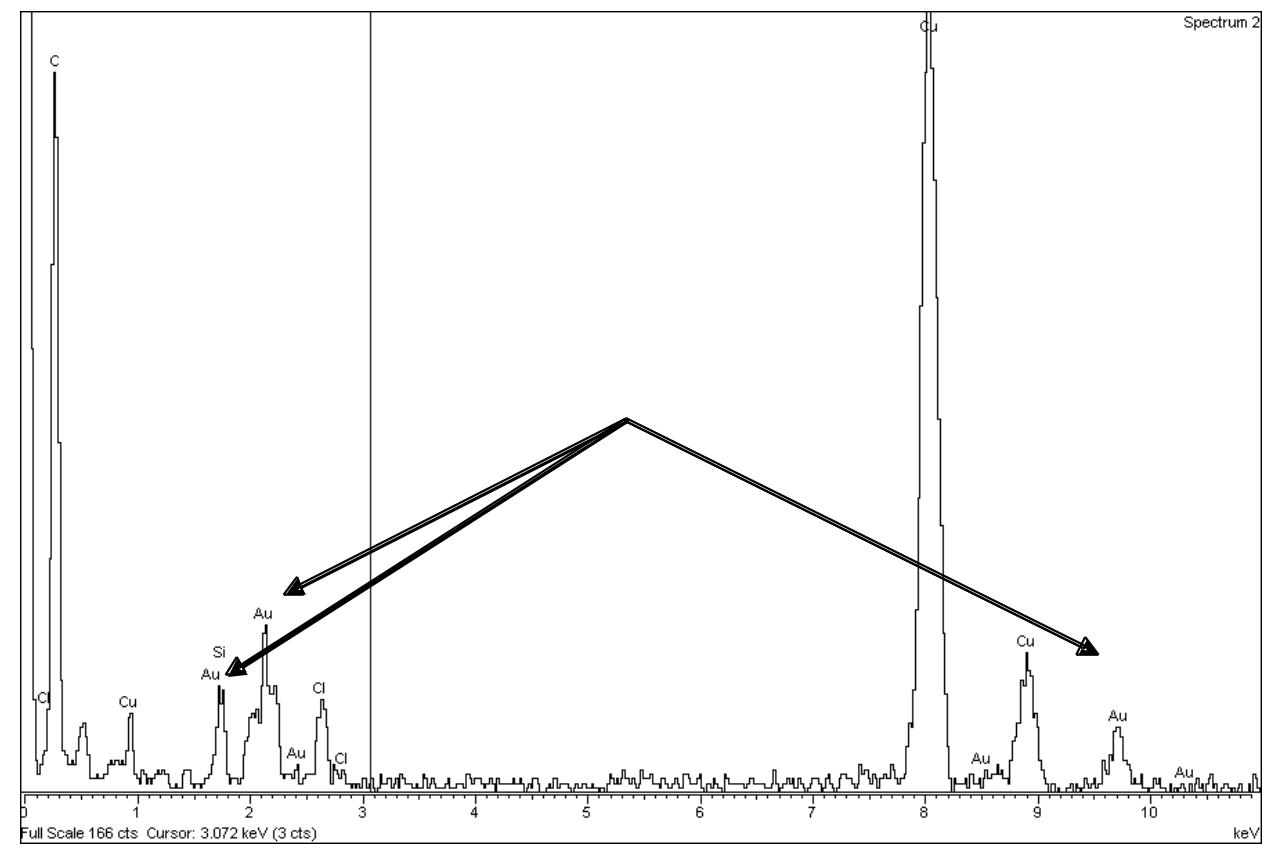

Fig SI 2. X-ray powder difractogram of nano-11. 